LANDSCAPE CONTEXT OF BEE, WASP AND PARASITOID DIVERSITY:

GRASS-STRIP CORRIDORS, FALLOWS AND FOOD WEBS

\author{
Dissertation \\ zur Erlangung des Doktorgrades \\ der Fakultät für Agrarwissenschaften \\ der Georg-August-Universität Göttingen
}

vorgelegt von

KRISTIN MARIE KREWENKA

geboren in Wolfenbüttel

Göttingen, Mai 2011 
D7

1. Referent: Prof. Dr. Teja Tscharntke

2. Korreferent: PD. Dr. Carsten F. Dormann

Tag der mündlichen Prüfung: 21. Juli 2011 


\section{INDEX OF FIGURES}

$\begin{array}{lll}\text { Figure } 1.1 & \text { Schematic drawing of the study design } & 10\end{array}$

Figure 1.2 The five studied habitat types \& environmental design 10

$\begin{array}{lll}\text { Figure } 1.3 & \text { Study organisms } & 11\end{array}$

Figure 2.1 Experimental design $\quad 27$

Figure 2.2 Trap nests and pan traps 28

Figure 2.3 Abundance of foraging bumblebees and solitary bees 33

Figure 2.4 Abundance of four functional predator groups 34

Figure 2.5 Parasitism rates of wasps and species richness of wasp parasitoids 35

Figure 3.1 Changes in the amount of fallows for Germany from the year 2006 until 2008 and abundance of solitary ground-nesting bees, above ground-nesting bees and bumblebees

Figure 3.2 Results of hierarchical partitioning analyses for the independent effects of habitat type and landscape attributes

Figure 3.3 Relationships between the abundance and species richness of the three pollinator groups 62

Figure A3.1 Mean species richness of flowering plants in five habitat types 76

Figure 4.1 Quantitative Food webs for the five different habitat types 86

Figure 4.2 Influence of landscape complexity and habitat type on species richness of hosts, parasitoids and parasitism rate

Figure 4.3 Effects of landscape complexity and habitat type on Shannon diversity, generality, linkage density, connectance and nestedness $\quad 90$

Figure A4.2 Species richness of flowering plants on the different study sites 106 


\section{INDEX OF TABLES}

Table 2.1 Results of the linear mixed-effects models 32

Table 2.2 Significant decline of species richness and abundance 33

Table 2.3 Effects of the grassland and strips on species parasitism rate, species richness of parasitoids and parasitized brood cells 36

Table A2.1 Survey of bee genera caught in the pan traps 50

Table A2.2 Results of the linear mixed-effects models with site as random factor $\quad 50$

Table A2.3 Survey of individuals occupying the trap-nests 51

Table 3.1 Landscape attributes in the years 2006-2008 and averaged climate characteristics $\quad 60$

Table 3.2 Abundance and species richness of solitary ground-nesting bees, bumblebees and above ground-nesting bees, over the years $\quad 60$

Table A3.2 Correlation matrix for the measured landscape attributes 76

Table A3.3 Survey of the percentage of independent effects resulting from hierarchical partitioning analyses $\quad 76$

Table 4.1 Effect of 5 habitat types and landscape complexity on abundance of hosts and parasitoids

Table 4.2 Results of the linear mixed effects models for the effects of landscape complexity

Table 4.3 Correlation matrix for abundance and species richness of host \& parasitoids, parasitism rates and food web indices $\quad 92$

Table A4.1 No. for species identification shown in the quantitative food webs 105 


\section{TABLE OF CONTENTS}

Index of Figures...................................................................................... ii

Index of Tables............................................................................................ iv

Chapter 1 General INTRODUCTION: LANDSCAPE CONTEXT OF BEE, WASP AND PARASITOID DIVERSITY

Introduction......................................................... 8

Study region $\&$ sites............................................... 9

Study organisms................................................ 11

Study objectives \& Chapter outline................................. 12

Results \& Conclusions.............................................. 13

References............................................................. 15

CHAPTER 2 LANDSCAPE ELEMENTS AS POTENTIAL BARRIERS AND CORRIDORS FOR BEES, WASPS AND PARASITOIDS

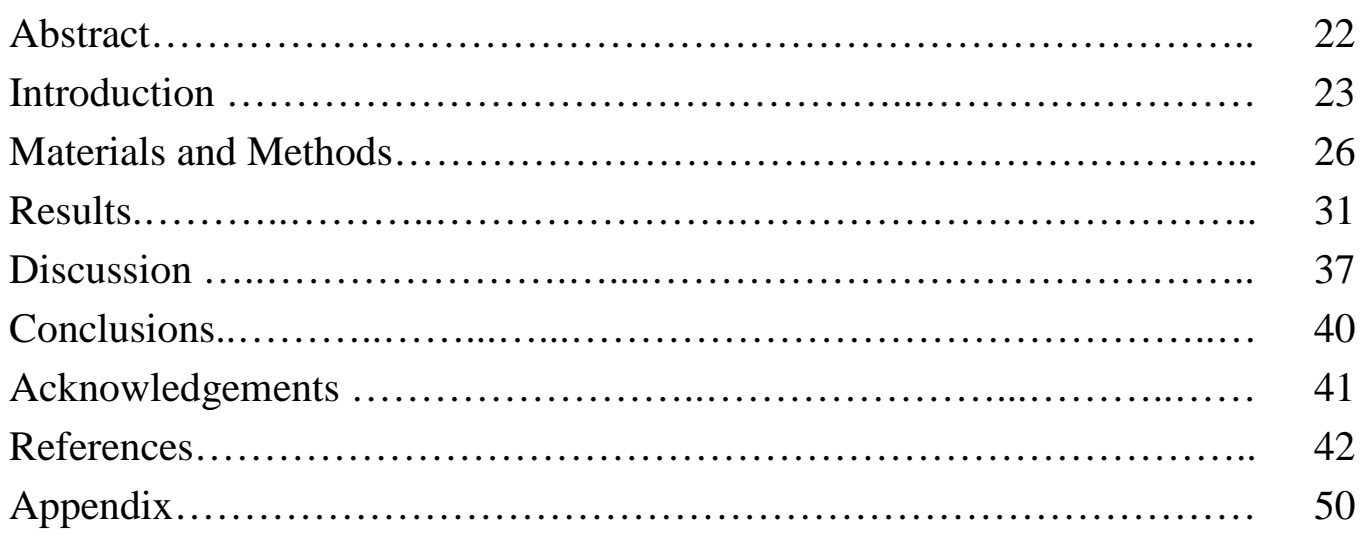

CHAPTER 3 BEE DIVERSITY AND FALLOW LOSS ACROSS AGRICULTURAL LANDSCAPES AND YEARS

Abstract........................................................... 53

Introduction.................................................... 54

Materials and Methods ................................................ 56

Results ........................................................ 59

Discussion ..................................................... 64

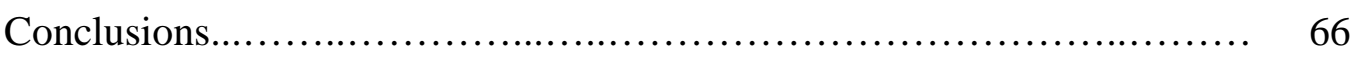

Acknowledgements................................................ 67 


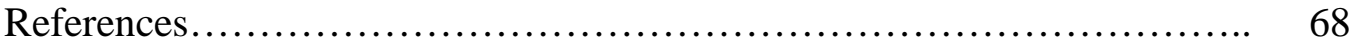

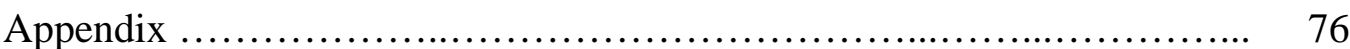

CHAPTER 4 SPECIES RICHNESS AND HOST-PARASITOID NETWORK STRUCTURE CHANGING WITH LAND USE TYPE AND LANDSCAPE COMPLEXITY

Abstract.......................................................... $\quad 78$

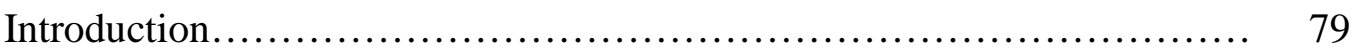

Material and Methods................................................. 82

Results ................................................................ 85

Discussion ......................................................... 93

Conclusions..................................................... 96

Acknowledgements.................................................. 97

References...................................................... 98

Appendix .............................................................. 105

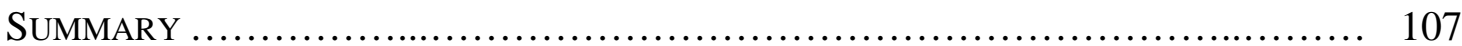

ZUSAMMENFASSUNG....................................................... 111

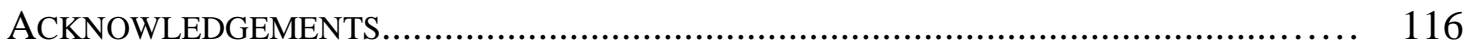

PublicAtions.............................................................. 118

CURRICULUM VITAE....................................................... 120 
CHAPTER 1

GENERAL INTRODUCTION

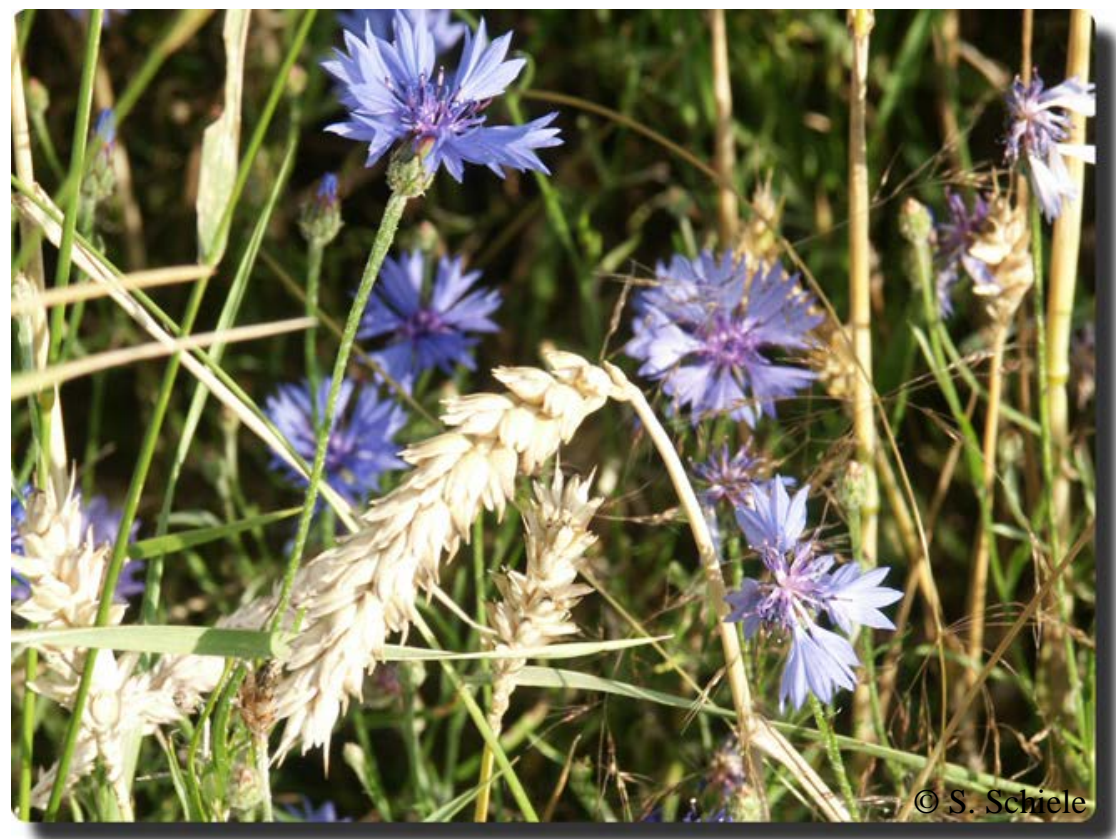




\section{INTRODUCTION}

Agricultural intensification has been identified as one of the main drivers of biodiversity decline (Tilman et al. 2001) and has become a major issue in conservation policy (Díaz et al. 2006). But the growing human population and associated increasing production request of food and energy plants are leading to conflicts with conservation of natural habitats, supporting biodiversity (Godfray et al. 2010). The diversity of species and their specific responses to disturbances or changes in resource availability is hypothesized to ensure biotic ecosystem services via complementarity or redundancy (Naeem 1998; Altieri 1999; McCann 2000). Therefore, biodiversity is essential to maintain ecosystem services, such as pollination and biological control which are important for human well-being and agricultural production (Corbet 1987; Landis, Wratten \& Gurr 2000; Klein et al. 2007). Increasing production areas resulting in large monocultures of annual crops, the loss or fragmentation of semi-natural habitats and the use of agrochemicals lead to a species poor environment (Benton, Vickery \& Wilson 2003; Weibull, Ostman \& Granqvist 2003). Previous studies showed the detrimental effects of habitat fragmentation and simplification of landscape structure on species diversity in the agricultural landscape (Fahrig 2003; Nentwig 2003; Landis et al. 2005; Ricketts et al. 2008; Tscharntke et al. 2007).

It is estimated, that two thirds of the world crops are depending on insect pollination for developing optimal yield (Williams 1994; Roubik 1995; Klein et al. 2007). Pollinator decline has been well documented in the last decades (Watanabe 1994; Cane 1997; Kremen, Williams \& Thorp 2002; Bijsmeier et al. 2006; Winfree et al. 2007; Potts et al. 2010). The loss of pollinators will result in high economic losses (Losey \& Vaughan 2006) and extinction of plants that are self-incompatible, and depend on insect pollination for reproduction (Aguilar et al. 2006). Biological control contributes to sustainable agriculture, but numbers of natural enemies of pest organisms must be high enough to serve as effective control agents (Costamagna \& Landis 2007; Gardiner et al. 2009). Semi-natural habitats have been shown to be beneficial to these insects, providing food resources and shelter from disturbances (Bianchi, Booij \& Tscharntke 2006; Fiedler, Landis \& Wratten 2008) Pollinators and natural enemies are multi habitat users (Klein et al. 2002; Tscharntke et al. 2005; Holzschuh, Steffan-Dewenter \& Tscharntke 2009) switching between high and low quality patches in the agricultural landscapes. Because of this, effects of different 
habitat types and landscape composition on pollinators and natural enemies have to be measured on a landscape scale. Species of higher trophic levels and with poor dispersal abilities are assumed to be more affected by changes in landscapes, than species that are highly mobile (Tscharntke et al. 2002; van Nouhuys 2005). Parasitoids may therefore be stronger affected by changes in landscape composition or alteration of habitats (Hanski 1999; Kruess \& Tscharntke 2000).

This thesis is the first study, using a large scale approach combining the effects of five local habitat types along a gradient of landscape complexity over three years on the abundance, species richness and trophic interactions of bees, wasps and their parasitoids. Furthermore, it contributes to the question, whether landscape elements, such as grass strips and hedges, influence foraging movements and dispersal of bees, wasps and their parasitoids in the agricultural landscape.

\section{STUDY REGION \& SITES}

All studies were carried out in the vicinity of the city of Göttingen, southern Lower Saxony, Germany. The landscape is dominated by intensive agriculture, interspersed with patches of forest and semi-natural habitats, such as calcareous grasslands, orchard meadows and hedges varying in size (Thies \& Tscharntke 1999).

For the first study we selected species-rich calcareous grasslands as source habitats for bees, predatory wasps and their parasitoids (WalliesdeVries, Poschlod \& Willems 2002). Connected and unconnected grassy field margin strips, which were hypothesized to function as corridors were selected in varying distances, to account for isolation effects. Additionally, hedges at the edge of the grasslands, which were $10 \mathrm{~m}^{2}$ or more in size and higher than $2 \mathrm{~m}$, were chosen to test for possible barrier effects by comparing grassland edges with and without hedges.

For the second and third study five habitat types, namely (i) conventionally managed wheat field, (ii) grassy field margin strip adjacent to the wheat field, (iii) conventionally managed meadow, mown at least twice a year and enriched with fertilizer, (iv) fallow and (v) forest edge in twelve non-overlapping landscape sectors with a varying amount of arable land in a radius of $1000 \mathrm{~m}$ around the focal habitat types ( $n=60)$ were chosen (Fig. 1.1 and Fig. 1.2). The amount of arable land, as estimator of landscape complexity, ranged from $12 \%$ (structurally complex landscape) to $89 \%$ (structurally simple landscape). 


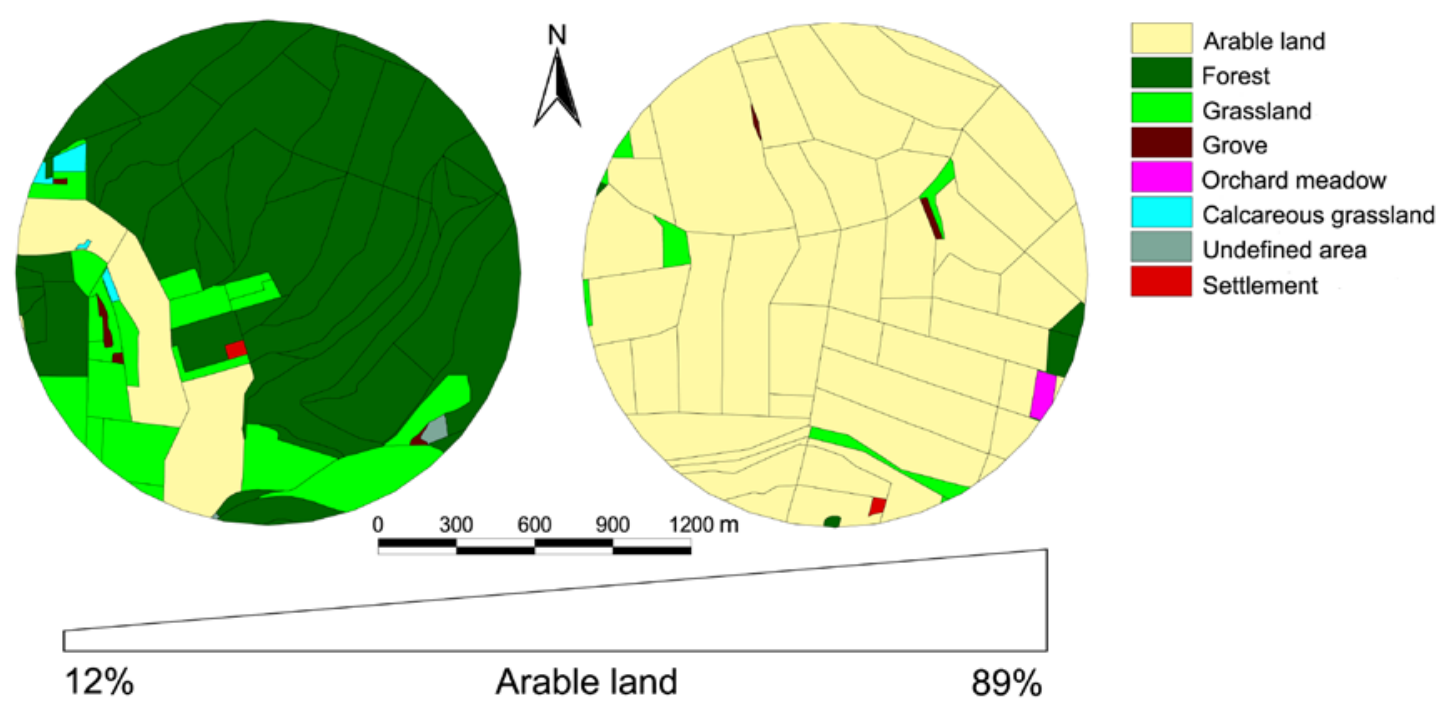

Figure 1.1 Schematic drawing of the study design of the second and third study: we selected five land use types of a 1000 m-radius along a gradient of varying landscape complexity, which is associated with the percentage of arable land, showing the two extremes of structurally complex (12\%) and simple landscapes (89\%).
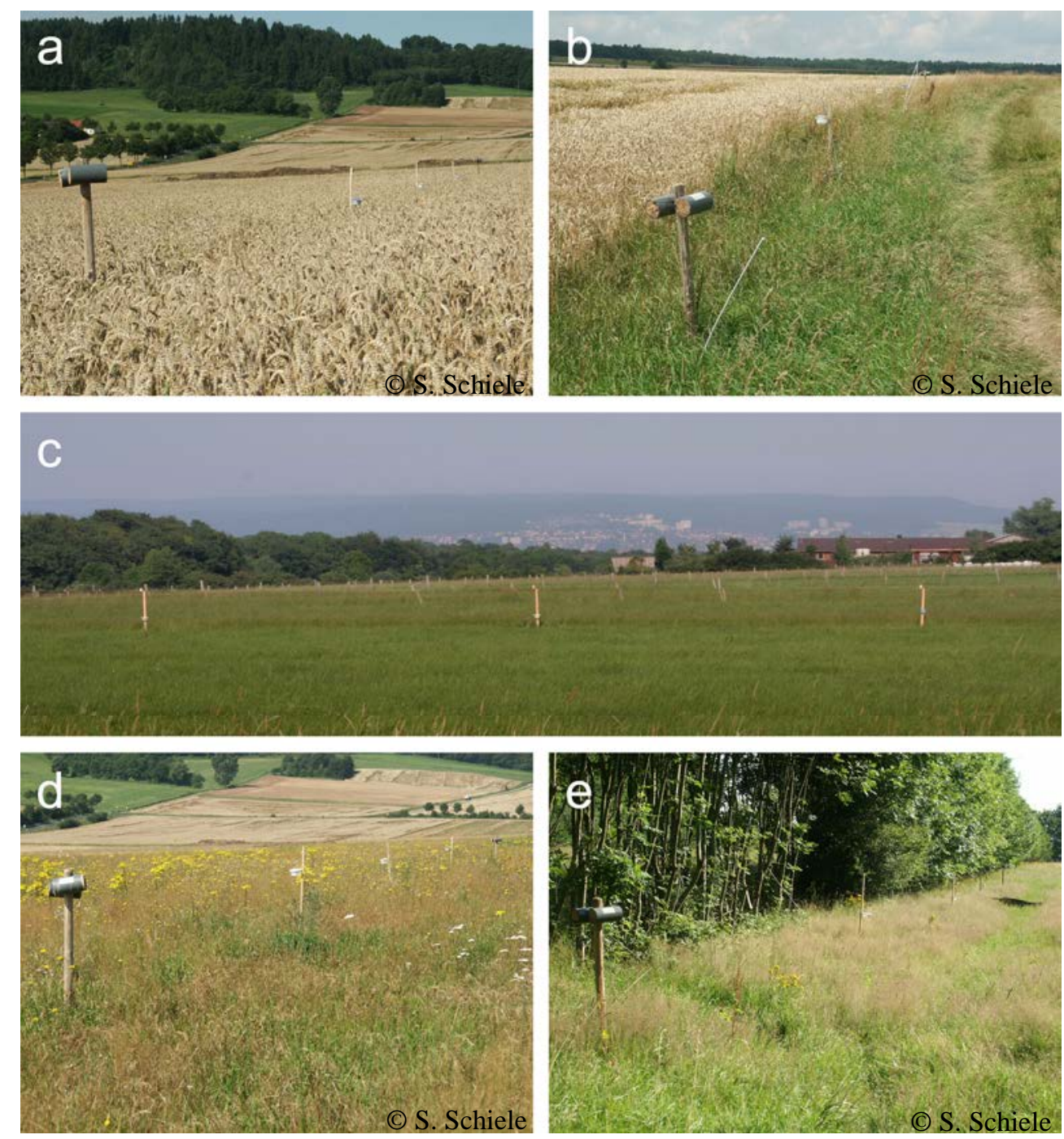

Figure 1.2 The five studied habitat types: (a) conventionally managed wheat field, (b) grassy field margin strip, (c) conventionally managed meadow, (d) fallow and (e) forest edge. 


\section{STUDY ORGANISMS}

Solitary and social wild bees are important pollinators of wild plants and crops (Cane 1997; Kremen, Williams \& Thorp 2002). Bees depend on semi-natural habitats, such as calcareous grasslands, shrub land and hedges in the landscape offering them flowering plant species as food resources and undisturbed areas as nesting sites (Batra 1984; Banaszak 1992; Westrich 1996).
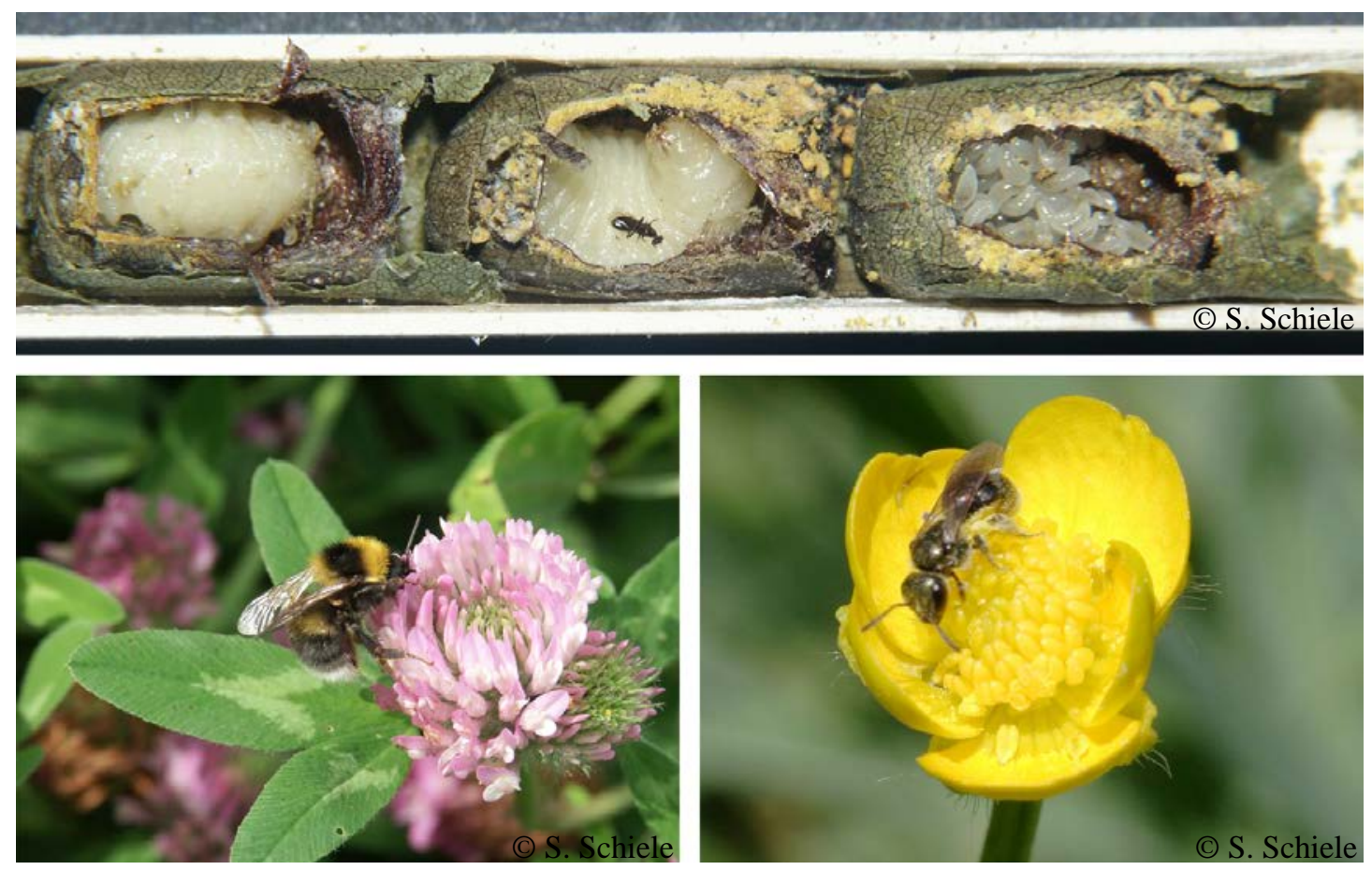

Figure 1.3 Larvae of trap-nesting bees of Megachilidae sp. partially parasitized by Melittobia acasta (above) in dissected reed internode of a trap nest, Bombus hortorum foraging on Trifolium pratense (left), Lasioglossum sp. foraging on Ranunculus sp. (right).

There are approximately 200 wild bee species located in the study region (Theunert 2003). Half of these are the ground-nesting bees, which have different nesting requirements than the above ground-nesting bees, which make roughly one fourth of the abundance, while the other bee species are brood parasites of both groups. Predatory wasps, hunting larvae of lepidopterans or bugs and aphids to provision their offspring, are contributing to biological control (Wearing \& Harris 2005). Adult individuals may also feed on lymph of the prey organisms, but rely on floral resources providing nectar as main food resource (Bellmann 2005). They are also affected by habitat and landscape alterations. Parasitoids of trap-nesting bees and wasps are 
important for regulation of populations and maintenance of species diversity by tempering host population fluctuations (Henson, Craze \& Memmott 2009).

Foraging bees were surveyed using pan traps, consisting of plastic bowls that were sprayed with UV-colour in white, blue and yellow to attract pollinators (Westphal et al. 2008). Dispersal of above ground-nesting bees, wasps and their parasitoids was monitored by using trap nests (Gathmann, Greiler \& Tscharntke 1994). Plastic tubes with a diameter of $12.5 \mathrm{~cm}$, filled with reed internodes of Phragmites australis in diameters of $0.2-1 \mathrm{~cm}$ are attractive nesting facilities for about 33 bees species and 55 predatory wasp species, in Germany (Tscharntke, Gathmann \& SteffanDewenter 1998) and their parasitoids. They are an efficient tool in assessing colonization success and parasitism events.

\section{STUDY OBJECTIVES \& CHAPTER OUTLINE}

This thesis deals with quantifying the relative importance of landscape elements, such as grassy strips and hedges, and differentially managed habitat types along a gradient of landscape complexity on the abundance, species richness and interactions of bees, wasps and their parasitoids in the agricultural landscape. The following hypotheses were tested:

- Bees, wasps and their parasitoids profit from semi-natural habitats in the agricultural landscape enhancing species richness and abundance and stabilizing interactions (Chapter 2, 3 \& 4).

- Movement and dispersal of bees, wasps and their parasitoids are facilitated by grass strip corridors, while foraging movement of bees is restricted by large hedges (Chapter 2).

- Bee communities benefit from increasing landscape complexity, and are less abundant and diverse in intensively managed habitat types, while the recent fallow loss will have negative effects on abundance and species richness of bees (Chapter 3).

- Intensively managed habitats and decreasing landscape complexity will lead to decreasing abundance and diversity of trap-nesting bees, wasps and their parasitoids and to alteration of their trophic interactions in two consecutive years (Chapter 4). 


\section{RESULTS \& CONCLUSIONS}

Bees, except foraging bumblebees, wasps and their parasitoids were negatively affected from isolation of semi-natural habitats. Their numbers and species richness decreased significantly with increasing distance from the source habitat. Functional groups of predatory wasps differed in sensitivity towards isolation. The hypothesis that grass strips in $100 \mathrm{~m}$ distance may function as corridors had to be rejected. No barrier effects of hedges could be detected, either.

The amount of fallows dropped more than $50 \%$ over the three years of the study. Abundance and species richness of solitary ground-nesting bees and bumblebees declined as well, while numbers and species richness of above ground-nesting bees remained stable. The abundance of bumblebees was positively influenced by the percentage of fallow in the landscape and species richness of bumblebees, and abundance and species richness of solitary ground-nesting bees were positively correlated with the amount of semi-natural habitats in the landscape. While groundnesting bees were influenced by percentage of landscape attributes, above groundnesting bees were mainly influenced by land use and most abundant and diverse on the forest edge, fallow and meadow, which harboured more flowering plant species than wheat field and field margin.

Intensively managed habitat types with low flowering plant diversity and low landscape complexity resulted in declining abundance and species richness of trapnesting bees, wasps and their parasitoids. Interactions were less diverse in intensively managed habitats such as wheat field and field margin. The connectance of species interactions as measure for network complexity increased with decreasing landscape complexity and was positively correlated with the mean number of shared hosts and shared predators, which results in enhanced consumer effects and may lead to extinction of species.

In conclusion, landscape simplification and habitat loss are negatively affecting abundance, species richness and interactions of bees, wasps and their parasitoids in the agricultural landscape. The loss of semi-natural habitats and low landscape complexity may result in cascading extinctions, due to species loss throughout resource limitation 
and shifts in trophic interactions. Semi-natural habitats are important sources of their bee and wasp diversity and abundance, but other habitat types may also be important , when their quality is enhanced by creating foraging or nesting resources for bees and wasps. Responses of different groups varied concerning the importance of habitat type or landscape composition, but lead to the same conclusions. Especially landscapes with high land use intensity should be improved by creating beneficial habitats for bees and wasps to support abundances, diversity and dispersal and throughout this ensure ecosystem services in the agricultural landscape. 


\section{REFERENCES}

Aguilar, R., Ashworth, L., Galetto, L. \& Aizen, M.A. (2006) Plant reproductive susceptibility to habitat fragmentation: review and synthesis through a metaanalysis. Ecology Letters, 9, 968-980.

Altieri, M.A. (1999) The ecological role of biodiversity in agroecosystems. Agriculture, Ecosystems \& Environment, 74, 19-31.

Banaszak, J. (1992) Strategy for conservation of wild bees in an agricultural landscape. Agriculture, Ecosystems \& Environment, 40, 179-192.

Batra, S.W.T. (1984) Solitary bees. Scientific American, 250, 120-127.

Bellmann, H. (2005) Bienen, Wespen, Ameisen, Hautflügler Mitteleuropas. Zweite Auflage. Franckh-Kosmos Verlags-GmbH \& Co. KG, Stuttgart, Germany.

Benton, TG., Vickery, J.A. \& Wilson, J.D. (2003) Farmland biodiversity: is habitat heterogeneity the key? Trends in Ecology and Evolution, 18, 182-188.

Bianchi, F.J.J.A., Booij, C.J.H. \& Tscharntke, T. (2006) Sustainable pest regulation in agricultural landscapes: a review on landscape composition, biodiversity and natural pest control. Proceedings of the Royal Society B - Biological Sciences, 273, 1715-1727.

Biesmeijer, J.C., Roberts, S.P.M., Reemer, M., Ohlemüller, R., Edwards, M., Peeters, T., Schaffers, A.P., Potts, S.G., Kleukers, R., Thomas, C.D., Settele, J. \& Kunin, W.E. (2006) Parallel declines in pollinators and insect-pollinated plants in Britain and the Netherlands. Science, 313, 351-354.

Cane, J.H. (1997) Ground nesting bees: the neglected pollinator resource for agriculture. Acta Horticulturae, 437, 309-324.

Corbet, S. (1987) More bees make better crops. New Scientist, 115, 40-43. 
Costamagna, A.C. \& Landis, D.A. (2007) Quantifying predation on soybean aphid through direct field observations. Biological Control, 42, 16-24.

Diaz, S., Fargione, J., Chapin, F.S. III \& Tilman, D. (2006) Biodiversity loss threatens human well-being. PLoS Biology, 4, e277.

Fahrig, L. (2003) Effects of habitat fragmentation on biodiversity. Annual Review of Ecology, Evolution and Systematics, 34, 487-515.

Fiedler, A.K., Landis, D.A. \& Wratten, S.D. (2008) Maximizing ecosystem services from conservation biological control: The role of habitat management. Biological Control, 45, 254-271.

Gardiner, M.M., Landis, D.A., Gratton, C., Schmidt, N., O'Neal, M., Mueller, E., Chacon, J.,Heimpel, G.E. \& DiFonzo, C.D. (2009) Landscape composition influences patterns of native and exotic lady beetle abundance. Diversity and Distribution, 15, 554-564.

Gathmann, A., Greiler, H.J. \& Tscharntke, T., (1994) Trap-nesting bees and wasps colonizing set-aside fields: Succession and body-size, management by cutting and sowing. Oecologia, 98, 8-14.

Godfray, H.C.J., Crute, I.R., Haddad, L., Lawrence, D., Muir, J.F., Nisbett, N., Pretty, J., Robinson, S., Toulmin, C. \& Whiteley, R. (2010) The future of the global food system Introduction. Philosophical Transactions of the Royal Society BBiological Sciences, 365, 2769-2777.

Hanski, I. (1999) Habitat connectivity, habitat continuity, and metapopulations in dynamic landscapes. Oikos, 87, 209-219.

Henson, K.S.E., Craze, P.G. \& Memmott, J. (2009) The restoration of parasites, parasitoids, and pathogens to heathland communities. Ecology, 90, 1840-1851.

Holzschuh, A., Steffan-Dewenter, I. \& Tscharntke, T. (2009) Grass strip corridors in 
agricultural landscapes enhance nest-site colonization by solitary wasps. Ecological Applications, 19, 123-132.

Klein, A.M., Vaissiere, B.E., Cane, J.H., Steffan-Dewenter, I., Cunningham, S.A., Kremen, C. \& Tscharntke, T. (2002) Importance of pollinators in changing landscapes for world crops. Proceedings of the Royal Society B - Biological Sciences, 274, 303-313.

Klein A.M., Vaissière B.E., Cane J.H., Steffan-Dewenter I., Cunningham S.A., Kremen C. \& Tscharntke T. (2007) Importance of pollinators in changing landscapes for world crops. Proceedings of the Royal Society B - Biological Sciences, 274, 303-313.

Kremen, C., Williams, N.M. \& Thorp, R.W. (2002) Crop pollination from wild bees at risk from agricultural intensification. Proceedings of the National Academy of Scienes of the United States of America, 99, 16812-16816.

Kruess, A. \& Tscharntke, T. (2000) Species richness and parasitism in a fragmented landscape: experiments and field studies with insects on Vicia sepium. Oecologia, 122, 129-137.

Landis, D.A., Wratten, S.D. \& Gurr, G.M. (2000) Habitat management to conserve natural enemies of arthropod pests in agriculture. Annual Review of Entomology, 45, 175-201.

Landis, D.A., Menalled, F.D., Costamagna, A.C. \& Wilkinson, T.K. (2005) Manipulating plant resources to enhance beneficial arthropods in agricultural landscapes. Weed Science, 53, 902-908.

Losey, J.E. \& Vaughan, M. (2006) The economic value of ecological services provided by insects. Bioscience, 56, 311-323.

McCann, K.S. (2000) The diversity-stability debate. Nature, 405, 228-233. 
Naeem, S. (1998) Species redundancy and ecosystem reliability. Conservation Biology, 12, 39-45.

Nentwig, W. (2003) Management of biodiversity in agroecosystems. Basic and Applied Ecology, 4, 105-106.

Potts S.G., Roberts S.P.M., Dean R., Marris G., Brown M., Jones R. \& Settele J. (2010) Declines of managed honeybees and beekeepers in Europe. Journal of Apicultural Research, 49, 15-22.

Ricketts, T.H., Regetz, J., Steffan-Dewenter, I., Cunningham, S.A., Kremen, C., Bogdanski, A., Gemmill-Herren, B., Greenleaf, S.S., Klein, A.M., Mayfield, M.M., Morandin, L.A., Ochieng, A. \& Viana, B.F. (2008) Landscape effects on crop pollination services: are there general patterns? Ecology Letters, 11, $499-515$.

Roubik, D.W. (1995) Pollination of cultivated plants in the tropics. FAO Agricultural Services Bulletin, 118, 1-161.

Theunert, R. (2003) Atlas zur Verbreitung der Wildbienen (Hym.: Apidae) in Niedersachsen und Bremen (1973-2002). Ökologieconsult, Hohenhameln, Germany.

Thies, C. \& Tscharntke, T. (1999) Landscape structure and biological control in agroecosystems. Science, 285, 893-895.

Tilman, D., Fargione, J., Wolff, B., D'Antonio, C., Dobson, A., Howarth, R., Schindler, D., Schlesinger, W.H., Simberloff, D. \& Swackhamer, D. (2001) Forecasting agriculturally driven global environmental change. Science, 292, 281-284.

Tscharntke, T., Gathmann, A. \& Steffan-Dewenter, I. (1998) Bioindication using trapnesting bees and wasps and their natural enemies: community structure and interactions. Journal of Applied Ecology, 35, 708-719. 
Tscharntke, T., Steffan-Dewenter, I., Kruess, A. \& Thies, C. (2002) Characteristics of insect populations on habitat fragments: A mini review. Ecological Research, 17, 229-239.

Tscharntke, T., Klein, A.M., Kruess, A., Steffan-Dewenter, I. \& Thies, C. (2005) Landscape perspectives on agricultural intensification and biodiversity ecosystem service management. Ecology Letters, 8, 857-874.

Tscharntke, T., Bommarco, R., Clough, Y., Crist, T.O., Kleijn, D., Rand, T.A., Tylianakis, J.M., van Nouhuys, S. \& Vidal, S. (2007) Conservation biological control and enemy diversity on a landscape scale. Biological Control, 43, 294-309.

van Nouhuys, S. (2005) Effects of habitat fragmentation at different trophic levels in insect communities. Annales Zoologici Fennici, 42, 433-447.

WallisDeVries, M.F., Poschlod, P. \& Willems, J.H. (2002) Challenges for the conservation of calcareous grasslands in northwestern Europe: integrating the requirements of flora and fauna. Biological Conservation, 104, 265-273.

Watanabe, M.E. (1994) Pollination worries rise as honey-bees decline. Science, 265, $1170-1170$.

Wearing, C.H. \& Harris, A.C. (2005) Evaluation of the predatory wasp, Ancistrocerus gazella, for biological control of leafrollers in Otago fruit crops. II. Wasp phenology and seasonal changes in prey composition. Biocontrol Science and Technology, 15, 281-298.

Weilbull, A.C., Ostman, O. \& Granqvist, A. (2003) Species richness in agroecosystems: the effect of landscape, habitat and farm management. Biodiversity and Conservation, 12, 1335-1355.

Westphal, C., Bommarco, R., Carre, G., Lamborn, E., Morison, N., Petanidou, T., Potts, S.G., Roberts, S.P.M., Szentgyorgyi, H., Tscheulin, T., Vaissiere, B.E., 
Woyciechowski, M., Biesmeijer, J.C., Kunin, W.E., Settele, J. \& SteffanDewenter, I. (2008) Measuring bee diversity in different European habitats and biogeographical regions. Ecological Monographs, 78, 653-671.

Westrich, P. (1996) Habitat requirements of Central European bees and the problems of partial habitats. The conservation of bees (eds A. Matheson, S.L. Buchmann, C.O`Toole, P. Westrich \& I.H. Westrich), pp. 1-16. Academic press, London, UK.

Williams, I.H. (1994) Bees for pollination - conclusions and recommendations of the EC workshop on bees for pollination held in Brussels 2-3 March 1992. Bee World, 75, 46-48.

Winfree, R., Williams, N.M., Dushoff, J. \& Kremen, C. (2007) Native bees provide insurance against ongoing honey bee losses. Ecology Letters, 10, 1105-1113. 
CHAPTER

LANDSCAPE ELEMENTS AS POTENTIAL BARRIERS AND CORRIDORS FOR BEES, WASPS AND PARASITOIDS

Kristin M. Krewenka, Andrea Holzschuh, Teja Tscharntke, Carsten F. Dormann

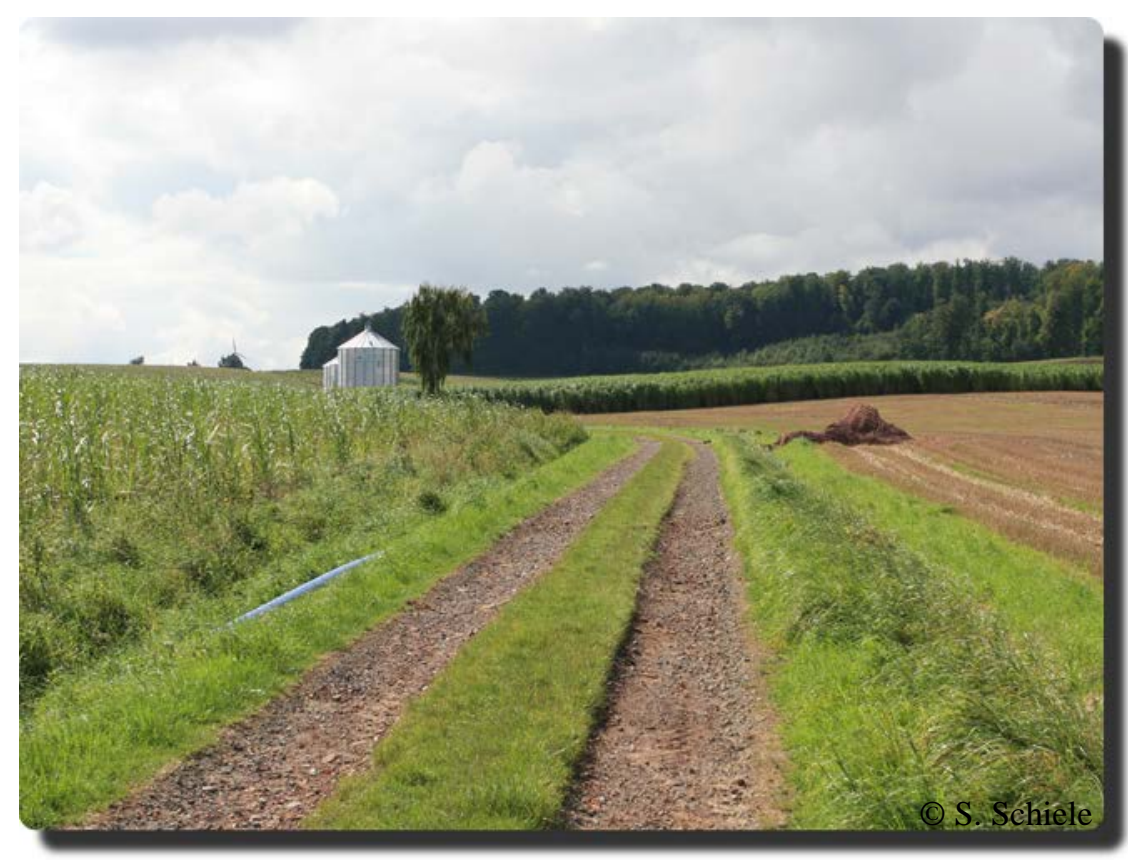

Published in: Biological Conservation 2011, 144, 1816-1825.

(copyright is held by Elsevier together with the authors) 


\section{ABSTRACT}

Habitat loss and fragmentation in agricultural landscapes lead to severe declines of abundance and richness of many insect species in the remaining isolated semi-natural habitats. We analysed possible barrier effects of large hedges and corridor effects of narrow grass strips that were hypothesized to affect foraging and dispersal of hymenopterans. We selected calcareous grasslands in the vicinity of Göttingen (Germany), which harbour high Hymenoptera diversity and are starting points for foraging and dispersal in the landscape. We installed pan traps to sample bees (i) on the grasslands; (ii) on grassland edges behind adjacent hedges (potential barriers) and without hedges; (iii) on grass strips in $100 \mathrm{~m}$ distance to the grassland, which were connected or unconnected to the grassland; and (iv) unconnected (isolated) grass strips in $300 \mathrm{~m}$ and $750 \mathrm{~m}$ distance to test for corridor and isolation effects on abundance and species richness of foraging wild bees. Additionally we provided trap nests for bees, wasps and their parasitoids on the grasslands and the strips. Species abundance and richness declined with increasing isolation from grasslands for foraging solitary bees, trap-nesting bees, wasps and parasitoids, but not for foraging bumblebees. Hedges did not confine movement of foraging bees. We found no mitigating effects of $(100 \mathrm{~m})$ corridor strips on any of the observed groups. We conclude that conservation of seminatural habitats as sources of bee and wasp diversity is important and that grass strips act as sinks rather than corridors when high quality patches are nearby.

\section{KEY WORDS}

Agricultural landscape, bees, corridors, grass strips, hedges, wasps 


\section{INTRODUCTION}

Fragmentation and loss of habitat caused by agricultural intensification has been identified as one of the biggest threats to biodiversity in agricultural landscapes, causing a reduction of abundance and diversity of insects in remaining, isolated habitat patches (Saunders, Hobbs \& Margules 1991; Tilman et al. 2001; Benton, Vickery \& Wilson 2003; Fahrig 2003; Winfree et al. 2009). Corridors have often been proposed as a strategy to connect habitat fragments and mitigate negative effects of fragmentation (Haddad et al. 2003; Sutcliffe \& Thomas 1996). On the other hand, barrier effects of hedgerows are also known to restrict movement of some invertebrate species (Dover \& Fry 2001; Kuefler et al. 2010), although the knowledge of corridor and barrier effects on the movement and dispersal of bees and wasps and their parasitoids is limited (Holzschuh, Steffan-Dewenter \& Tscharntke 2009; Zurbuchen et al. 2010). Bees and wasps contribute widely to ecosystem services such as pollination of crops and wild plants (Cane 1997; Winfree et al. 2007) and biological control (Klein et al. 2007; Tylianakis, Klein \& Tscharntke 2005), but are increasingly threatened by fragmentation (Tscharntke \& Brandl 2004; Larsen, Williams \& Kremen 2005; Ricketts et al. 2008).

The number of wild bees has decreased over the last centuries because of vanishing nesting and food resources in the intensively managed agricultural landscape (Kremen, Williams \& Thorp 2002; Steffan-Dewenter, Potts \& Packer 2005; Biesmeijer et al. 2006). This problem is intensified by the ongoing loss of managed honey bees due to increasing pressure by pests and diseases and low economic return (Watanabe 1994; Downey \& Winston 2001, De la Rua et al. 2009; Potts et al. 2010). Predatory wasps, nesting in tree trunks or branches in semi-natural habitats are also challenged by the modification of the agricultural landscape (Tylianakis, Tscharntke \& Klein 2006). Without suitable nesting habitats the predation of pest organisms by these predatory wasps is likely to decrease with increasing isolation (Holzschuh, SteffanDewenter \& Tscharntke 2009). Higher trophic levels are supposed to suffer even more from isolation of habitat patches (Albrecht et al. 2007; Holt et al. 1999).

Linear landscape elements, such as grass strips or hedgerows, are considered as conservation tools for enhancing biodiversity in the agricultural landscape through mitigating negative isolation effects (Rosenberg, Noon \& Meslow 1997; Beier \& Noss 1998). Yet, the empirical evidence for corridor effects of such narrow habitat strips is 
limited and taxon-specific. Many studies investigating corridor effects on plants and animals have been conducted in a forest matrix with cleared grassland plots (Tewksbury et al. 2002; Haddad \& Tewksbury 2005; Townsend \& Levey 2005; Damschen et al. 2006), and these results cannot be readily transferred to the situation in intensively used agricultural landscapes. There are even studies indicating negative effects of corridors, such as grassy strips in open landscapes, proliferating pests or invasive species (Proches et al. 2005; Alofs \& Fowler 2010). Moreover, corridors in fragmented landscapes could enhance parasitoid species richness and abundance as well, affecting host populations in alternative habitats.

Hedges have been shown to be valuable landscape elements for conservation of bird, mammal and arthropod populations (Varchola \& Dunn 2001; Pollard \& Holland 2006; Brambilla, Rubolini \& Guidali 2007; Michel et al. 2007), including cavitynesting bees and wasps, which construct their nests in the branches of hedges (Holzschuh, Steffan-Dewenter \& Tscharntke 2009). However, hedges can also function as obstacles for invertebrates, enhancing isolation effects as shown for lepidopteran species (Fry 1995) and for carabid beetles (Mauremooto et al. 1995).

Our main objectives in this study were to assess whether hedges inhibit colonization of habitat patches and whether grass strips function as corridors for wild bees, predatory wasps and their parasitoids. The grass strips, situated along crop field margins and up to three metres wide, are common in agricultural landscapes in central Europe. We selected grass strips connected to species-rich calcareous grassland and unconnected grass strips varying in distance from the grassland. We expected connectivity to matter to foraging of wild bees and colonization success of trap-nesting bees and wasps. In addition we focused on hedgerows that separated the potential grass strip corridor from the grassland to test whether hedges can function as barriers inhibiting the movement of wild bees. To our knowledge, our study is the first to use these typical grass strips of varying distances to semi-natural source habitats of wild bees to test for potential corridor and also potential barrier effects of hedgerows on bees and wasps and their parasitoids in the agricultural landscape. Specifically, our hypotheses were:

(i) Abundance and species richness of wild bees and cavity-nesting wasps and their parasitoids decline with increasing isolation from the source habitat. 
(ii) Abundance and species richness of wild bees and trap-nesting wasps are higher on grass strips that are connected to a semi-natural habitat than on unconnected grass strips.

(iii) Hedges can function as an obstacle and restrict foraging movements of wild bees.

(iv) Parasitism rates of hosts in the trap nests decline with increasing isolation and are higher in connected than unconnected strips. 


\section{MATERIALS AND METHODS}

\section{EXPERIMENTAL SITES}

The study took place in summer 2007 in the vicinity of the city of Göttingen, located in the south of Lower Saxony, Germany. Göttingen is surrounded by shell limestone, featuring extensively managed calcareous grasslands, which are protected conservation areas. These calcareous grasslands are known to be valuable habitats for many flowering plant species and a huge variety of bee and wasp species (Wallies DeVries, Poschlod \& Willems 2002). They are nutrient-poor locations and created by grazing by goats, sheep or small horses. The calcareous grasslands host nesting resources for cavity-nesting bee and wasp species, such as shrubs and hedges, which partly surround the grasslands (Steffan-Dewenter \& Tscharntke 1999). The dry, sandy soil with only bare vegetation is attractive for ground-nesting bees.

For our experiment we selected 17 calcareous grasslands, which we considered to be source habitat for dispersal and daily foraging of bees and wasps. The mean area of the grasslands was 2.7 ha \pm 0.8 ha (mean $\pm \mathrm{SEM}$; $\min =0.1$ ha, $\max =16.9$ ha). Focusing on isolation and possible corridor effects, we observed hymenopteran movement on narrow, approximately $3 \mathrm{~m}$ broad grass strips connected and unconnected to the grassland.

Data were collected (i) directly at source grasslands ( $n=17)$; (ii) at connected grass strips located $100 \mathrm{~m}$ from the grassland $(\mathrm{n}=13)$; at unconnected grass strips located (iii) $100 \mathrm{~m}(\mathrm{n}=8)$; (iv) $300 \mathrm{~m}(\mathrm{n}=6)$ and (v) $750 \mathrm{~m}(\mathrm{n}=11)$ from the grassland (Fig. 2.1). The calcareous grasslands are high quality habitats and therefore not directly comparable to the low quality grass strips; they were used as benchmark, since abundance and species richness are expected to be maximal on these grasslands. It was not possible to find calcareous grasslands with adjacent grass strips of all required isolation levels. Thus, the number of grass strip replicates differs among treatments. Flower density and the width of grass strips did not differ among treatments (strip width: lme, $F_{3,9}=3.50, p=0.063$; flower density: lme, $F_{3,9}=0.33, p=0.805$ ).

To test for possible barrier effects of hedges, we selected five calcareous grasslands with a dense hedge on one edge, which was larger than ten square metres and higher than two metres. Four of these grasslands were also used in the corridor and isolation experiments, therefore the set of pan traps in the centre of the grasslands could be used for both experimental set ups. 
a)

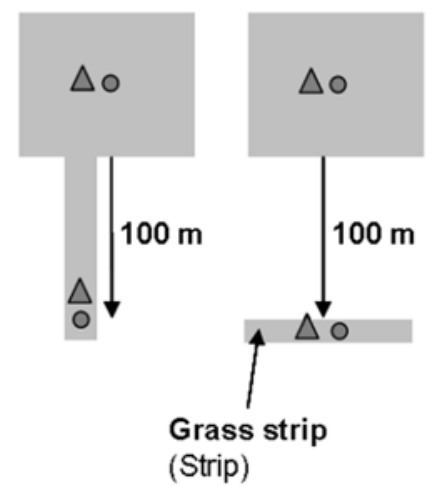

b)

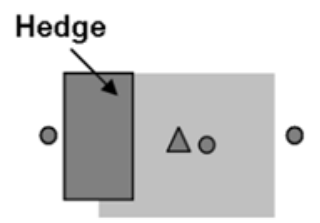

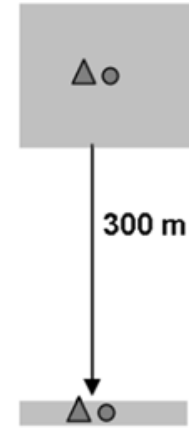

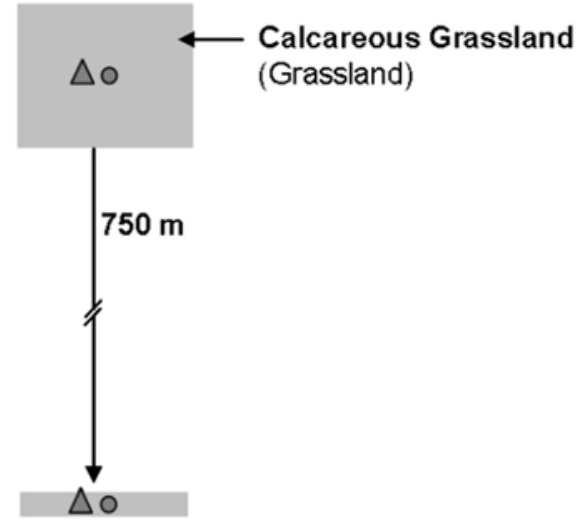

Figure 2.1 Experimental design. All sites were embedded in the agricultural landscape matrix. Corridor experiment: a) Trap nests and pan traps were installed in the middle of each calcareous grassland and parallel to these in connected and unconnected grassy strips in the given distances $(100 \mathrm{~m}, 300 \mathrm{~m}$, $750 \mathrm{~m}$ ). Barrier experiment: b) On five calcareous grasslands with hedges on one side, pan traps were exposed behind the hedge and on the edge without hedge to test for possible barrier effects.

\section{SURVEY OF FORAGING BEES AND TRAP-NESTING BEES AND WASPS}

We installed a total of 110 pan traps in the centre of the calcareous grasslands and on the grass strips in the mentioned distances from the traps on the grassland (Fig. 2.2). To account for foraging movements of wild bees, we chose pan traps, which attract the bees by their colour (Westphal et al. 2008). One set of pan traps comprised two plastic soup bowls in yellow and blue, sprayed with UV-reflecting colour (Sparvar®) and filled with a mixture of ethylene glycol and water plus one drop of detergent. They were placed at one metre height on a wooden pole. Pan traps were exposed for three weeks (from $17^{\text {th }}$ of July to $7^{\text {th }}$ of August) and emptied at weekly intervals. On four locations the pan traps were destroyed, so we had to exclude them from analyses. Thus, the pan trap data set was reduced to (i) 16 source grasslands; 12 connected grass strips (ii) in 100 m, 7 unconnected grass strips in (iii) $100 \mathrm{~m}$ and 5 grass strips in 300 m distance from the grassland. We installed additionally 11 sets of pan traps: one set in the centre of each grassland, one set directly behind the hedge facing the wheat field, and one set on the opposite side at the edge of the calcareous grassland next to a winter wheat field (Fig.2.1b). 


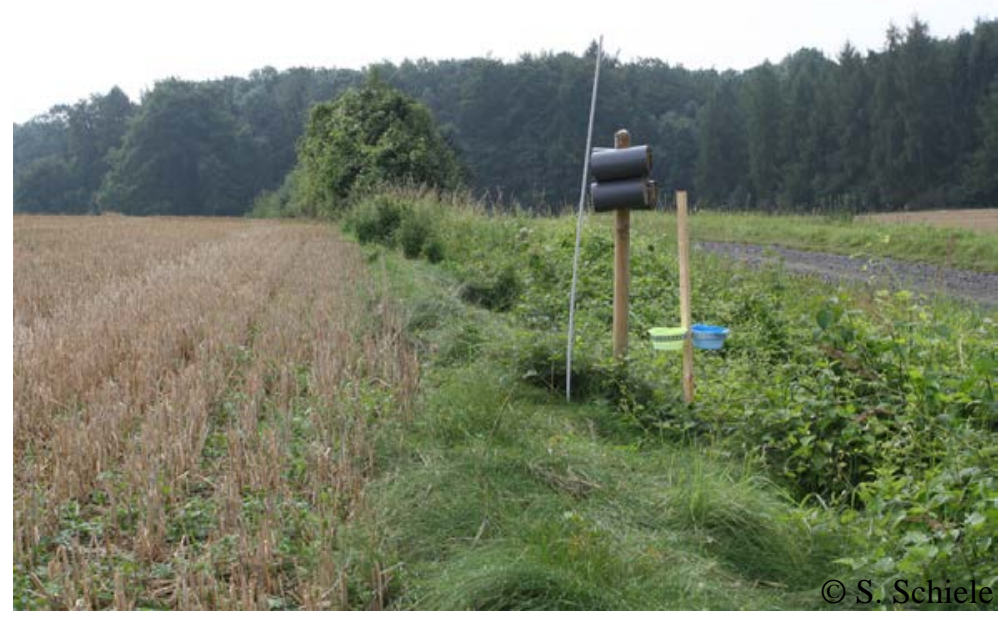

Figure 2.2 Trap nests and pan traps installed on the grassy field margin strip, adjacent to the wheat field

Trap nests are an established tool to assess the colonization activity of nesting specialists, such as cavity nesting bees and wasps, as well as the distribution and activity of their parasitoids (Tscharntke, Gathmann \& Steffan-Dewenter 1998). We placed in total 216 trap nests on the grasslands and grass strips, located $20 \mathrm{~cm}$ besides the pan traps at a height of $1.30 \mathrm{~m}$. One set of trap nests consisted of a wooden pole with four plastic tubes with a diameter of $10.5 \mathrm{~cm}$, each filled with approximately 200 reed internodes of diameters between $0.2 \mathrm{~cm}$ and $1.0 \mathrm{~cm}$. The trap nests were put out from $15^{\text {th }}$ of April to the $5^{\text {th }}$ of October 2007. The occupied reed internodes were dissected and brood cells were counted. The numbers of parasitized brood cells, dead and undeveloped larvae were recorded. The occupied reed internodes were stored in glass vials at $4^{\circ} \mathrm{C}$ for six weeks to simulate winter season and after that at room temperature to stimulate larval development. Emerging adults (hosts and parasitoids) were identified to species level. If no adult emerged, features of the nest and larval food were used to identify the genus or subfamily. Empty brood cells of eumenid wasps were assumed to belong to the bivoltine Ancistrocerus nigricornis, since offspring of the first generation emerged before trap collecting. We used no trap nests in the barrier experiment since hedges are nesting sites for most above-ground nesting bee and wasp species and we hence expected no barrier effect of hedges for these groups.

All bees and wasps were identified to species level. Bombus terrestris and Bombus lucorum were pooled to Bombus terrestris agg. Bumblebees and solitary bees were analysed separately. The semi-social species of the genus Lasioglossum were included in the group of the solitary bees, while the domesticated honeybees (Apis 
mellifera) were excluded from any analysis. We focused on the following species groups: foraging solitary bees, foraging bumblebees, trap-nesting bees and trap-nesting wasps, and the parasitoids of trap-nesting bees and wasps. Trap-nesting wasps were further divided into four functional groups with respect to the prey for their larvae. The first group consisted of wasps of the genus Ancistrocerus spp., which attack lepidopteran larvae (Schmid-Egger 2004). The second group consisted of wasps of the genus Symmorphus spp., which are specialized on larvae of Chrysomelidae and Curculionidae. (Budriené 2003). Species richness of the genus Symmorphus was not analysed, because only two species occurred and one of these was present in two nests only. The third group consisted of the aphid-preying genera Passaloecus, Pemphredon and Psenulus (Sphecidae). Finally the fourth group consisted of the spider-preying genera Trypoxylon (Sphecidae), Dipogon and Auplopus (Pompilidae).

\section{VEGETATION SURVEY}

On the grass strips we recorded the species richness of flowering plants and the flower cover in the middle of July on a transect of $25 \mathrm{~m}$ in each direction of the traps. Flower cover was generally very low $(0.97 \% \pm 0.06 \%$, mean $\pm \mathrm{SEM}$, $\min =0.40 \%$, $\max =$ $1.76 \%, \mathrm{n}=38$ grass strips) with on average $7.4 \pm 0.59$ plant species per grass strip (mean \pm SEM, $\min =4, \max =20$ ). The average width of the grass corridors was 1.06 $\mathrm{m} \pm 0.56 \mathrm{~m}$ (mean $\pm \mathrm{SEM}, \min =0.37 \mathrm{~m}, \max =2.42 \mathrm{~m}, \mathrm{n}=38$ grass strips).

\section{STATISTICAL ANALYSES}

Species richness is the total number of species per pan trap set or trap nests on each grassland and grass strip. Abundances in pan traps are the mean number of individuals caught over the two traps of a pan trap set and three rounds. Abundances in trap nests are the total numbers of brood cells per trap nest set. To assess the effect of grass-strip isolation, we fitted linear mixed-effects models with isolation level as fixed factor and site as random factor. Response variables were the abundance and species richness of wild bees in the pan traps and the colonization, species richness and parasitism rates of trap-nesting bees and wasps and the functional groups of wasps. The random factor corrected for the fact that grass strips of different isolation level surrounding one grassland were not independent from each other. Abundances of Symmorphus spp. were too low to conduct a linear mixed-effects model analysis, so we used a Pearson's $\chi^{2}$-test with presence-absence matrix. Parasitism rates were calculated by dividing the 
parasitized brood cells by the number of all host brood cells. Parasitism rates were analyzed only for sites with a number of host brood cells $>0$ and not analysed for the functional wasp groups separately, since the number of parasitism events was too low. We also tested whether parasitoid species richness and parasitism rate depended on host species richness and included the isolation level as additional explanatory variable in the model. We analysed barrier effects of hedges, employing mixed-effect models with abundance and species richness of foraging bees as dependent variable, trap locations as fixed factor (centre of grassland vs. edge of the grassland with hedge vs. edge of the grassland without hedge) and site as random factor. Corridor effects on abundance and species richness were tested by strip type as fixed factor (connected grass stips in $100 \mathrm{~m}$ vs. unconnected grass strip in $100 \mathrm{~m}$ ) and site as random factor. To fulfil the criteria of normality of errors the data for species richness, abundance and number of brood cells were $\log _{10}(\mathrm{x}+1)$-transformed. The percentage values of parasitism rates were arcsine-square-root transformed (Crawley 2008). The statistical analyses were conducted using R (version 2.10.0; R Development Core Team 2009) and the package nlme (Pinheiro et al. 2009). If results showed significant p-values, they were tested with the post-hoc general linear hypothesis test, using the packages multcomp and multcompView (Hothorn, Bretz \& Westfall 2008). P-values were corrected using the Holm method for multiple comparisons (Aickin \& Gensler 1996). 


\section{RESULTS}

In the intact 102 pan traps of the corridor experiment we caught in total 488 individuals. These were 203 bumblebees of eleven species (including Psithyrus spp.) and 285 solitary bee individuals of 36 species, mainly represented by the genus Lasioglossum (211 individuals). In the additional 24 pan traps of the barrier study 301 foraging bees were caught. The dominant genus was again Lasioglossum with 229 individuals.

In the trap nests, bees and wasps built 3308 brood cells. In total, we found 13 species of six bee genera. The most abundant genus of bees was Hylaeus, present in 436 brood cells, followed by Chelostoma with 196 and Heriades with 117 brood cells. Overall we identified 23 wasp species of 12 genera. The most abundant wasp genera were the spider predators of the genus Trypoxylon, which built 1100 brood cells, the predators of lepidopteran larvae, constructing 804 brood cells and the aphid predators Passaloecus spp. with 761 brood cells.

The parasitism rate in the trap nests was $19.2 \% \pm 2.6 \%$ (mean $\pm \mathrm{SEM}$, min $=$ $0 \%$, $\max =58.3 \%, \mathrm{~N}=3369$ ). We found 13 species of (klepto-) parasitoids and one predator species (larvae of Megatoma undata), which we included in the analysis of parasitism. Seven parasitoid species attacked bees only, four species attacked wasps only and three parasitoid species were found in both bee and wasp nests.

\section{ISOLATION EFFECTS WITH INCREASING DISTANCE FROM THE SOURCE HABITAT}

We tested for isolation effects by comparing the abundance and species richness of foraging bees and trap-nesting bees and wasps on the grassland to the connected grass strip in $100 \mathrm{~m}$ distance and the isolated grass strips in $100 \mathrm{~m}, 300 \mathrm{~m}$ and $750 \mathrm{~m}$ distance.

The abundance of foraging solitary bees and trap-nesting bees was significantly reduced in the isolated grass strips at $300 \mathrm{~m}$ and $750 \mathrm{~m}$ distance (Fig. 2.3a, 2.3c). Species richness of foraging solitary bees was lower in the grass strip in $750 \mathrm{~m}$, whereas the species richness of trap-nesting bees declined already from $300 \mathrm{~m}$ distance onwards (Table 2.1, Table 2.2).

Wasps were divided into four functional groups: predators of lepidopteran larvae, predators of chrysomelid larvae, predators of spiders and predators of aphids. 
Table 2.1 Results of the linear mixed-effects models testing the effects of isolation on species richness and abundance of foraging bees, trap-nesting bees and wasps and three functional groups of trap-nesting wasps, comparing the grassland, Connected grass strip in $100 \mathrm{~m}$ distance (Con. strip 100) and grass strips (strips) in mentioned distances. (Predators of chrysomelid larvae were excluded, since no linear mixed effect model was conducted, due to low sample size). Values are for the full model and for pairwise post-hoc comparisons after Holm correction.

\begin{tabular}{|c|c|c|c|c|c|c|c|c|c|c|c|c|c|c|}
\hline \multirow[b]{2}{*}{ Species richness } & \multicolumn{2}{|c|}{$\begin{array}{c}\text { Foraging } \\
\text { solitary bees }\end{array}$} & \multicolumn{2}{|c|}{$\begin{array}{l}\text { Foraging } \\
\text { bumblebees }\end{array}$} & \multicolumn{2}{|c|}{$\begin{array}{l}\text { Trap-nesting } \\
\text { bees }\end{array}$} & \multicolumn{2}{|c|}{$\begin{array}{l}\text { Trap-nesting } \\
\text { wasps }\end{array}$} & \multicolumn{2}{|c|}{$\begin{array}{l}\text { Lepidopteran } \\
\text { larvae predators }\end{array}$} & \multicolumn{2}{|c|}{ Aphid predators } & \multicolumn{2}{|c|}{$\begin{array}{c}\text { Spider } \\
\text { predators }\end{array}$} \\
\hline & $F_{4,21}$ & $P$ & $F_{4,21}$ & $P$ & $F_{4,25}$ & $P$ & $F_{4,25}$ & $P$ & $\mathrm{~F}_{4,25}$ & $P$ & $\mathrm{~F}_{4,25}$ & $P$ & $\mathrm{~F}_{4,25}$ & $P$ \\
\hline Full model & 5.4 & 0.004 & 0.3 & 0.904 & 8.3 & $<0.001$ & 11.3 & $<0.001$ & 3.4 & 0.024 & 11.3 & $<0.001$ & 17.5 & $<0.001$ \\
\hline Grassland - con. strip 100 m & & 1.000 & & & & 0.085 & & $<0.001$ & & 0.087 & & 0.009 & & $<0.001$ \\
\hline Grassland - strip 100 m & & 1.000 & & & & 0.238 & & 0.216 & & 0.145 & & 0.334 & & $<0.001$ \\
\hline Grassland - strip 300 m & & 0.128 & & & & 0.005 & & $<0.001$ & & 0.119 & & 0.002 & & $<\mathbf{0 . 0 0 1}$ \\
\hline Grassland - strip 750 m & & 0.007 & & & & $<0.001$ & & $<0.001$ & & 0.806 & & $<0.001$ & & $<0.001$ \\
\hline Con. strip 100 m - strip 100 m & & 1.000 & & & & 1.000 & & 0.340 & & 1.000 & & 0.450 & & 1.000 \\
\hline Strip 100 m - strip 300 m & & 0.083 & & & & 0.192 & & 0.754 & & 1.000 & & 0.450 & & 1.000 \\
\hline Con. strip 100 m -strip 750 m & & 0.001 & & & & 0.056 & & 0.360 & & 1.000 & & 0.030 & & 0.642 \\
\hline Strip 100 m - strip 300 m & & 0.281 & & & & 0.150 & & 0.150 & & 1.000 & & 0.099 & & 1.000 \\
\hline Strip 100 m - strip 750 m & & 0.023 & & & & 0.046 & & 0.016 & & 1.000 & & 0.002 & & 1.000 \\
\hline Strip 300 m - strip 750 m & & 1.000 & & & & 1.000 & & 0.754 & & 1.000 & & 0.450 & & 1.000 \\
\hline \multicolumn{15}{|l|}{ Abundance } \\
\hline Full model & 9.74 & $<0.001$ & 0.7 & 0.624 & 7.5 & $<0.001$ & 17.6 & $<0.001$ & 1.7 & 0.181 & 38 & $<0.001$ & 38.0 & $<0.001$ \\
\hline Grassland - con. strip 100 m & & 0.118 & & & & 0.143 & & $<0.001$ & & & & 0.003 & & $<0.001$ \\
\hline Grassland - strip 100 m & & 0.396 & & & & 0.167 & & 0.042 & & & & 0.354 & & $<0.001$ \\
\hline Grassland - strip 300 m & & 0.002 & & & & 0.003 & & 0.010 & & & & $<0.001$ & & $<0.001$ \\
\hline Grassland -strip 750 m & & $<0.001$ & & & & 0.001 & & $<0.001$ & & & & $<0.001$ & & $<0.001$ \\
\hline Con. strip 100 m- strip 100 m & & 1.000 & & & & 1.000 & & 1.000 & & & & 0.354 & & 1.000 \\
\hline Strip 100 m - strip 300 m & & 0.024 & & & & 1.667 & & 1.000 & & & & 0.354 & & 1.000 \\
\hline Con. strip 100 m - strip 750 m & & 0.006 & & & & 1.667 & & 1.000 & & & & 0.017 & & 1.000 \\
\hline Strip 100 m - strip 300 m & & 0.048 & & & & 0.193 & & 1.000 & & & & 0.016 & & 1.000 \\
\hline Strip 100 m - strip 750 m & & 0.012 & & & & 0.193 & & 0.696 & & & & $<0.001$ & & 1.000 \\
\hline Strip 300 m - strip 750 m & & 1.000 & & & & 1.000 & & 1.000 & & & & 0.416 & & 1.000 \\
\hline
\end{tabular}


Table 2.2 Grass strip type and distance at which species richness and abundance significantly decline compared to species richness and abundance on calcareous grasslands for connected strips in $100 \mathrm{~m}$ (Con. strip 100) and grass strips (strip) in the mentioned distances.

\begin{tabular}{|c|c|c|}
\hline & $\begin{array}{l}\text { Significant decline of } \\
\text { species richness }\end{array}$ & $\begin{array}{l}\text { Significant decline of } \\
\text { abundance }\end{array}$ \\
\hline Foraging solitary bees & Strip 750 & Strip 300 \\
\hline Foraging bumblebees & no decline up to Strip 750 & no decline up to Strip 750 \\
\hline Trap-nesting bees & Strip 300 & Strip 300 \\
\hline Trap-nesting wasps & Con. Strip 100 & Con. strip 100 \\
\hline Wasps: predators of lepidopteran larvae & no decline up to Strip 750 & no decline up to Strip 750 \\
\hline Wasps: predators of chrysomelid larvae & NA & Con. Strip 100 \\
\hline Wasps: predators of aphids & Con. Strip 100 & Con. Strip 100 \\
\hline Wasps: predators of spiders & Con. Strip 100 & Con. Strip 100 \\
\hline Parasitoids of trap-nesting bees & no decline up to Strip 750 & no decline up to Strip 750 \\
\hline Parasitoids of trap-nesting wasps & Con. Strip 100 & Con. Strip 100 \\
\hline
\end{tabular}
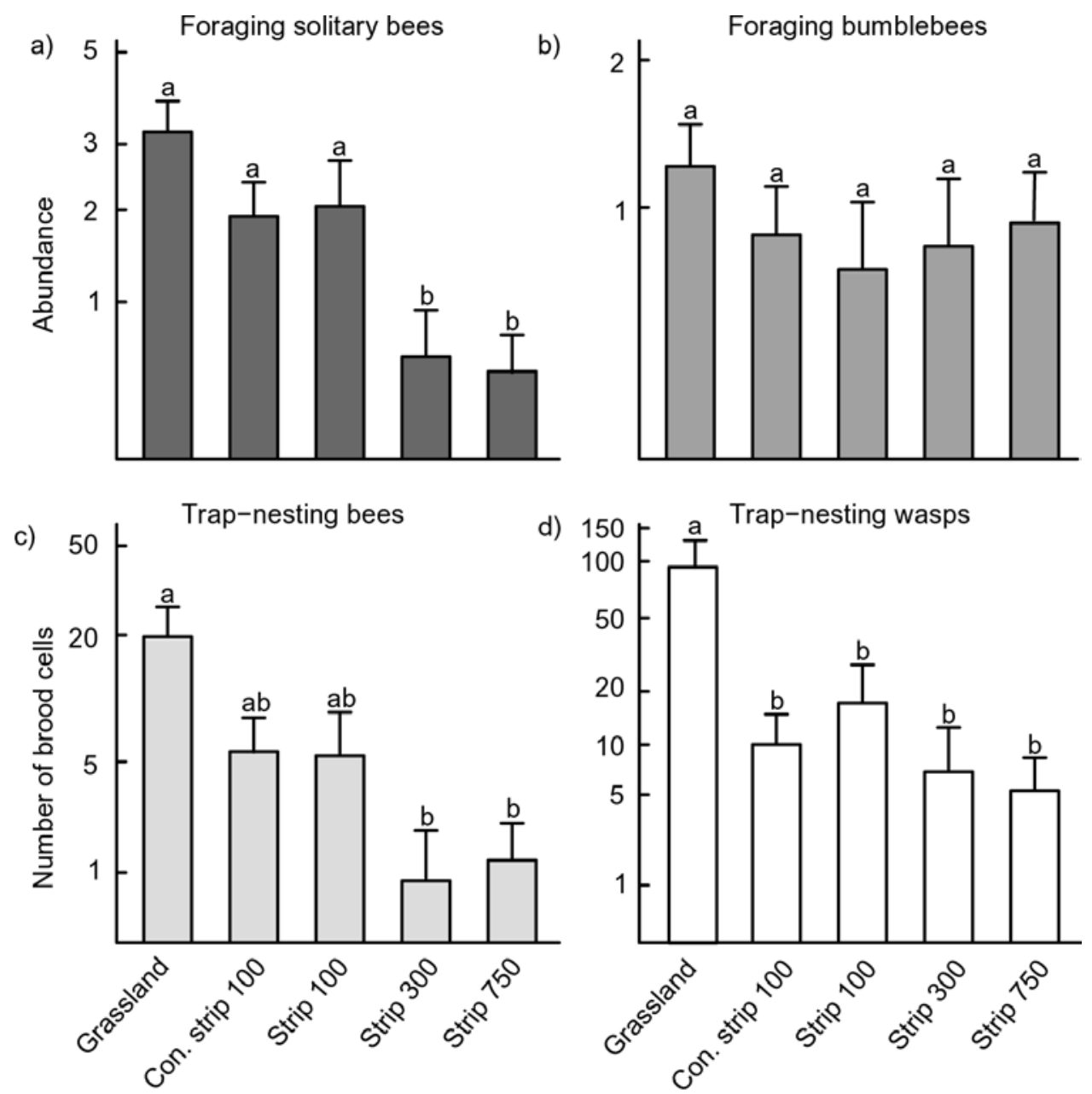

Figure 2.3 Abundance of foraging bees. Abundance of a) foraging solitary bees and of b) foraging bumblebees in the pan traps and the number of brood cells of c) trap-nesting bees and d) trap-nesting wasps in the trap nests of the grassland the connected strip in $100 \mathrm{~m}$ (Con. strip 100) and the unconnected grass strips in $100 \mathrm{~m}, 300 \mathrm{~m}$ and $750 \mathrm{~m}$. Figures are based on mean values + SEM, $P$ values are corrected after pairwise post-hoc comparisons using the Holm method. 
Number of brood cells and species richness of all trap-nesting wasps, as well as the functional groups of trap-nesting wasps and their parasitoids, were significantly higher on the grassland than the grass strips (Table 2.2, Fig. 2.3c, Fig. 2.4, Fig. 2.5). An exception were the predators of lepidopteran larvae that showed no response to increasing isolation of the grass strips (lme: $F_{4,25}=1.554, p=0.217$ ) (Fig. 2.4), but species richness was lower on the connected grass strip in $100 \mathrm{~m}$ distance compared to the isolated grass strips (Table 2.1, Table 2.2). We found no effect of isolation on the abundance and species richness of foraging bumblebees (Table 2.1, Table 2.2, Fig. 2.3b) and on the parasitoids of trap-nesting bees.

a) Predators of lepidopteran larvae
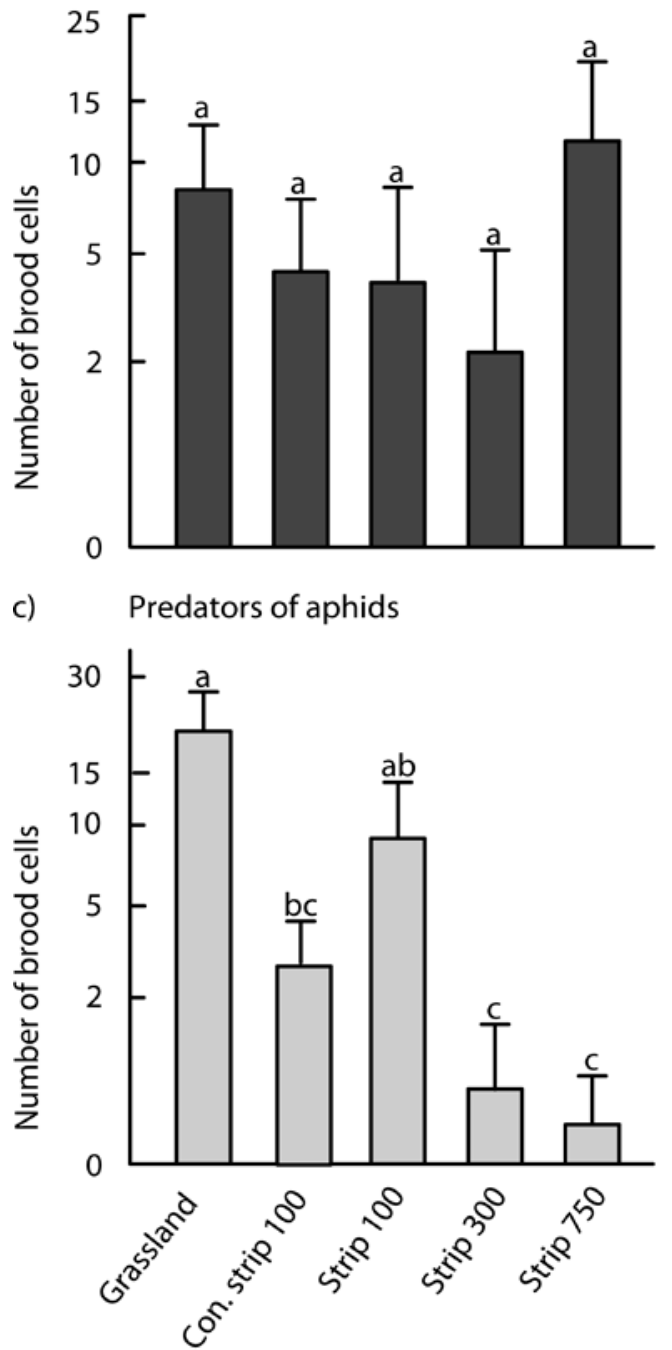

b) Predators of chrysomelid larvae

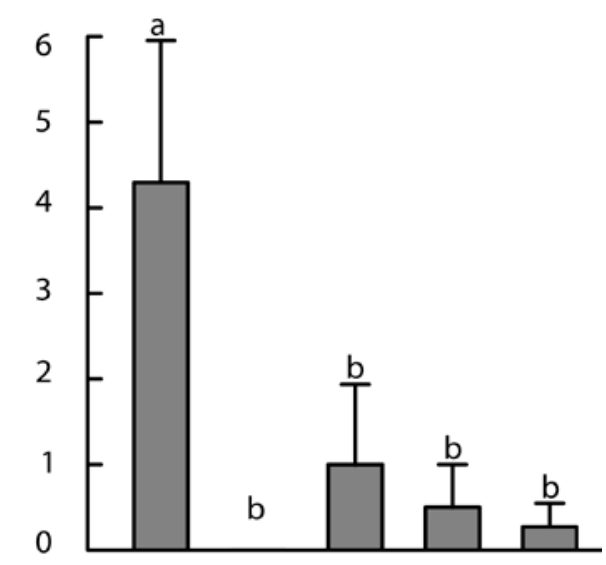

d)

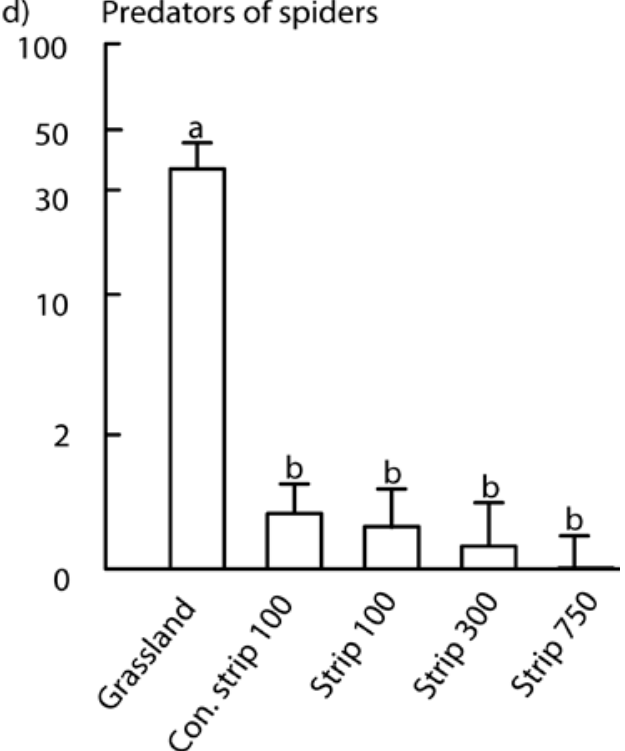

Figure 2.4 Abundance of the four functional groups. Mean number + SEM of brood cells for the functional groups of wasps in the trap nests of the grassland, the connected strip in $100 \mathrm{~m}$ (Con. strip 100) and the unconnected grass strips (Strip) in $100 \mathrm{~m}, 300 \mathrm{~m}$ and $750 \mathrm{~m}$. a) Predators of lepidopteran larvae (Ancistrocerus spp.), b) predators of chrysomelid larvae (Symmorphus spp.), c) aphid predators and d) spider predators. $P$-values are for the full model and for pairwise post-hoc treatment comparisons using the Holm method. 
Parasitism rates of trap-nesting wasps were highest on the grassland and were significantly lower on the grass strip in $750 \mathrm{~m}$ distance (Table 2.2, Table 2.3, Fig. 2.5). Species richness of trap-nesting bees and wasps was positively correlated with the number of brood cells (lme: bees, $\mathrm{F}_{1,14}=22.54, P<0.001$; wasps, $\mathrm{F}_{1,19}=63.5, P<$ 0.001) and species richness of parasitoids increased with the species richness of hosts (lme: bees, $\mathrm{F}_{1,14}=29.28, P<0.001$; wasps, $\mathrm{F}_{1,19}=85.18, P<0.001$ ).
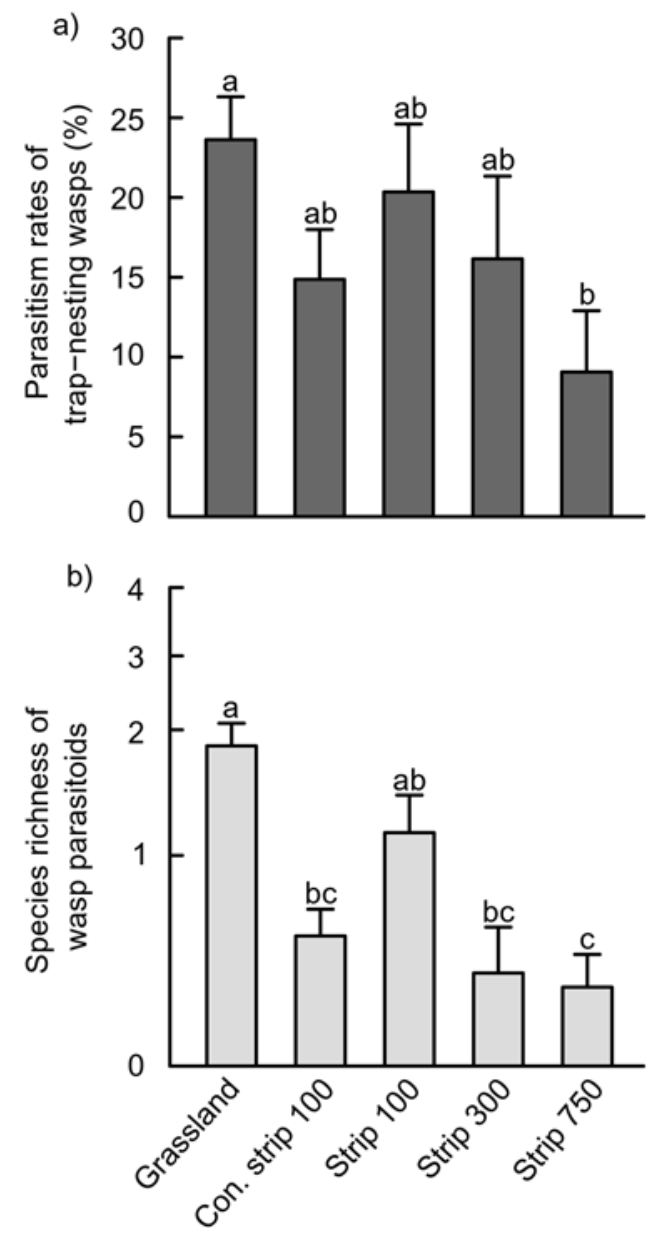

Figure 2.5 Parasitism rates of wasps and species richness of wasp parasitoids. a) Parasitism rates (\%) of trap-nesting wasps and b) species richness of wasp parasitoids on the grassland and the grass strips, based on mean values + SEM. $P$ values are for the full model and for pairwise posthoc treatment comparisons using the Holm method.

\section{CORRIDOR EFFECTS}

The models including the grassland and all grass strips showed no significant differences in abundance or species richness between the connected and non-connected grass strips in $100 \mathrm{~m}$ distance (Table 2.1). When directly comparing the two $100 \mathrm{~m}$ grass strips in the model, we found no significant effect for any of the observed groups (abundance: solitary foraging bees, lme: $\mathrm{F}_{1,3}=6.90, P=0.08$; bumblebees, lme: $\mathrm{F}_{1,3}=$ $0.26, P=0.643$; species richness: solitary foraging bees, lme: $\mathrm{F}_{1,3}=0.02, P=0.66$; 
bumblebees, lme: $\left.\mathrm{F}_{1,3}=0.24, P=0.655\right)$. Also abundance and species richness of trapnesting bees and wasps did not differ between the two grass strip types (abundance: bees, lme: $\mathrm{F}_{1,4}=0.03, P=0.879$; wasps, lme: $\mathrm{F}_{1,4}=0.01, P=0.913$; species richness: bees, lme: $F_{1,4}=0.013, P=0.914$; wasps, lme: $F_{1,4}=0.044, P=0.844$, for results for the functional groups of wasps see Appendix, A2.3).

Table 2.3 Effects of the grassland and the different strips, (connected strip in $100 \mathrm{~m}=$ con. strip 100; grass strips $=$ strip plus the distance of $100 \mathrm{~m}, 300 \mathrm{~m}$ and $750 \mathrm{~m}$ from the grassland), on the species parasitism rate, species richness of parasitoids and the number of parasitized brood cells for trap-nesting bees and wasps. Values are for the full model and for pairwise post-hoc treatment comparisons after Holm correction.

\begin{tabular}{|c|c|c|c|c|c|c|}
\hline \multirow[b]{2}{*}{ Trap-nesting wasps } & \multicolumn{2}{|c|}{ Parasitism rate } & \multicolumn{2}{|c|}{$\begin{array}{c}\text { Species richness of } \\
\text { parasitoids }\end{array}$} & \multicolumn{2}{|c|}{$\begin{array}{c}\text { Parasitized brood } \\
\text { cells }\end{array}$} \\
\hline & $\mathrm{F}_{4,20}$ & $P$ & $\mathrm{~F}_{4,20}$ & $P$ & $\mathrm{~F}_{4,20}$ & \\
\hline Full model & 3.429 & 0.027 & 15.320 & $<0.001$ & 15.7 & $<0.001$ \\
\hline Grassland - con. strip 100 m & & 0.174 & & $<0.001$ & & $<0.001$ \\
\hline Grassland - strip $100 \mathrm{~m}$ & & 1.000 & & 0.205 & & 0.004 \\
\hline Grassland-strip $300 \mathrm{~m}$ & & 1.000 & & 0.002 & & 0.004 \\
\hline Grassland-strip $750 \mathrm{~m}$ & & 0.043 & & $<0.001$ & & $<0.001$ \\
\hline Con. strip 100 m-strip 100 m & & 1.000 & & 0.072 & & 1.000 \\
\hline Strip $100 \mathrm{~m}$-strip $300 \mathrm{~m}$ & & 1.000 & & 0.892 & & 1.000 \\
\hline Con. strip $100 \mathrm{~m}$-strip $750 \mathrm{~m}$ & & 1.000 & & 0.588 & & 1.000 \\
\hline Strip $100 \mathrm{~m}$ - strip $300 \mathrm{~m}$ & & 1.000 & & 0.070 & & 1.000 \\
\hline Strip 100 m - strip 750 m & & 0.230 & & 0.006 & & 1.000 \\
\hline Strip 300 m - strip 750 m & & 1.000 & & 0.892 & & 1.000 \\
\hline Trap-nesting bees & $\mathrm{F}_{4,15}$ & & $\mathrm{~F}_{4,15}$ & & $\mathrm{~F}_{4,15}$ & \\
\hline Full model & 0.265 & 1.454 & 1.950 & 0.155 & 1.458 & 0.264 \\
\hline
\end{tabular}

\section{BARRIER EFFECTS OF HEDGES}

We compared the abundance and species richness of foraging bees in the pan traps on the grassland with the foraging bees caught on the edge of the grassland (i) behind a hedge and (ii) without a hedge. There was no detectable barrier effect on foraging solitary bees and foraging bumblebees (abundance: solitary foraging bees, lme: $F_{2,8}=$ 0.88, $P=0.452$; bumblebees, lme: $\mathrm{F}_{2,8}=0.28, P=0.762$; species richness: solitary foraging bees, lme: $\mathrm{F}_{2,8}=0.24, P=0.788$; bumblebees, lme: $\mathrm{F}_{2,8}=0.24, P=0.787$ ). 


\section{DISCUSSION}

The results of this study showed that isolation of narrow grass strips from large grassland negatively affected wild bees, predatory wasps and their parasitoids in the agricultural landscape, while neither hedges inhibited nor connecting grass strips facilitated dispersal. Habitat isolation affected nearly all observed guilds negatively. Abundance and species richness declined with increasing distance to the nearest grassland. Bees and wasps preferred the calcareous grassland as nesting habitat and starting point for daily forays. Exceptions from this pattern were the species richness and abundance of bumblebees, the abundance of predators of lepidopteran larvae and the abundance and species richness of parasitoids of bees. Abundance and species richness of foraging solitary bees declined with increasing distance from the source patch from a distance of $300 \mathrm{~m}$ onwards. Gathmann \& Tscharntke (2002) linked the foraging distance of bees to their body length, with bigger bees flying considerably longer distances than small bee species (see also Greenleaf et al. 2007). In fact, most of the captured foraging solitary bees were small with body sizes between five to nine millimetres, which suggests, according to Gathmann \& Tscharntke (2002), a foraging distance of 200-250 m and thus explains the rapid decline from a distance of $300 \mathrm{~m}$ onwards. The ground-nesting bees sampled in the pan traps showed a similar pattern to that found for the abundance and species richness of the trap-nesting bees, which declined also with increasing distance and were significantly lower on the grass strip in $300 \mathrm{~m}$ distance. This is in line with studies dealing with the negative impact of increasing isolation from species rich grassland and habitat patches on the abundance of flower-visiting bees (Steffan-Dewenter \& Tscharntke 1999; Albrecht et al. 2007).

Abundance and species richness of trap-nesting wasps were significantly higher on the calcareous grasslands than on the grass strips. These findings suggest that wasps prefer high quality habitats, but have the ability to colonize alternative habitats and to cover distances up to $750 \mathrm{~m}$. When taking a closer look at the wasps by splitting the data set into functional groups regarding their prey, we found that spider predators and aphid predators were more abundant on the grassland. The predators of chrysomelid larvae were only found on the grasslands. According to Budriené (2003), these wasps prefer chrysomelid prey associated with trees and curculionid larvae on flowering herbs, which appeared to be the reason why they were restricted to the calcareous grasslands. We did not find connectivity effects on the distribution of predators of 
lepidopteran larvae, in contrast to the study of Holzschuh, Steffan-Dewenter \& Tscharntke (2009), which focused on isolation from forest edges rather than grasslands. Forest edges are hosting more nesting sites than calcareous grasslands and are therefore more likely to function as source habitat for this species group.

The numbers of the aphid predators also declined with distance to the grassland yet were highest on the grass strips in $100 \mathrm{~m}$ distance. These aphid predators appeared to colonize even inferior nesting habitats when the prey availability in the surrounding wheat fields was high (Danks 1970). In this case, grass strips function as alternative habitat with a possible impact on biological control of aphid populations in adjacent crops. The richness of the spider-hunting guild dropped off rapidly between the grassland and any grass strips. This suggests that these genera are less flexible in terms of colonizing new nesting habitats. The most abundant genus of this group, Trypoxylon, hunts sheet web building spiders (Bellmann 2005), which are key spiders in grassland (Curry 1994). Trypoxylon uses grasslands as starting points for dispersal in other habitats in the agricultural landscape (Thomas \& Jepson 1997; Schmidt \& Tscharntke 2005).

Foraging bumblebees were distributed equally over the grassland and all grass strips, with no significant difference in species richness or abundance, even at $750 \mathrm{~m}$ distance. The very common generalist species Bombus terrestris, B. lucorum and $B$. lapidarius preferred field edges and banks as nesting sites (Kells \& Goulson 2003). These bumblebee species are not dependent on high quality habitat patches, as shown by Goulson et al. (2006). In contrast, Öckinger \& Smith (2007) found more bumblebees on field margins at $100 \mathrm{~m}$ compared to $1000 \mathrm{~m}$ distance from the next semi-natural grassland. This implies that there could be a distance effect for bumblebees on larger scales, which is consistent with the study by Westphal, SteffanDewenter \& Tscharntke (2006) showing landscape-wide bumblebee responses and the study by Knight et al. (2009), where the effective radius of available nesting and foraging sites for Bombus pascuorum was $1000 \mathrm{~m}$.

No significant corridor effect was found for any of the observed species groups. This is in line with the study by Collinge (2000), who did not find differences in the abundance of hymenopterans between the sites with and without corridors in a grassland matrix. Our results suggest that native bees do not orientate themselves on structures like field margins but have their specific foraging radius that they scan for adequate food and nesting resources. 
The lack of a corridor effect for trap-nesting species can potentially be explained by their occurrence being limited by suitable nesting sites. Abundance and species richness of trap-nesting bees and wasps is linked to the supply of suitable nesting sites in the focal habitat (Gathmann, Greiler \& Tscharntke 1994; Tscharntke, Gathmann \& Steffan-Dewenter 1998; Steffan-Dewenter 2003). The connected and the isolated grass strip in $100 \mathrm{~m}$ distance provided equal amounts of nesting resources. With additional nesting sites in the surrounding, grass strips could function as alternative habitats enhancing dispersal of trap-nesting bees and wasps and their ecosystem services.

Larger individuals with high dispersal abilities such as many bumblebees may experience effects of connected vs. unconnected grass strips only on larger scales. Parasitism rates of wasps were significantly higher on the grassland than on the grass strip in $750 \mathrm{~m}$ distance, supporting results of Tscharntke, Gathmann \& SteffanDewenter (1998). Species richness of wasp and bee parasitoids was positively correlated (i) with species richness of hosts and (ii) the number of parasitized brood cells, supporting the findings of Holzschuh, Steffan-Dewenter \& Tscharntke (2009, 2010) and Tylianakis, Tscharntke \& Klein (2006). We did not find isolation effects for parasitoids of bees, which may be due to the low numbers of trap-nesting bees and therefore low numbers of parasitism events.

Large hedgerows had no barrier effect on foraging pollinators. Since hedgerows are valuable nesting habitats for trap-nesting bees and wasps (Holzschuh, SteffanDewenter \& Tscharntke 2009), we focused on ground-nesting bees. Several studies found barrier effects of hedges, for example in carabid beetles (Mauremooto 1995). Flying insects seem to be more flexible in terms of crossing barriers, but their movement may be negatively influenced by hedgerows, leading to changes of directions or return to source habitat patches (Dover \& Fry 2001). In contrast to this, foraging bees did not appear to be affected, possibly also because hedgerows function as foraging habitat for bees (Freemark, Boutin \& Keddy 2002; Hannon \& Sisk 2009). 


\section{CONCLUSIONS}

Our findings showed that isolation distances of grass strips affected most Hymenoptera groups, while separating functional groups is crucial for understanding differences in sensitivity. Hedgerows are no barriers for wild bees including small ground-nesting bees and are not inhibiting dispersal of these bees into the adjacent agricultural landscape. We reject the hypothesis that grass strips, connecting habitats at a $100 \mathrm{~m}$ distance, function as corridors for wild bees, cavity-nesting wasps and their parasitoids. Common bumblebee species used grassland and grass strips similarly. Grass strips offer an additional foraging habitat when flowering species are promoted and mowing frequency remains low. In addition, nesting sites such as hedgerows or tree trunks help cavity nesting bees and wasps maintaining their diversity (Holzschuh, Steffan-Dewenter \& Tscharntke 2009). Our results emphasize that large semi-natural habitats such as calcareous grasslands need to be protected as sources of bee and wasp diversity. Increasing the quality of grass strips may support bee and wasp diversity by serving as low-quality habitat (Brown \& Paxton 2009), in particular when embedded in a large-scale habitat matrix, while small-scale habitat connectivity did not appear to be very important. 


\section{ACKNOWLEDGEMENTS}

We thank Susanne Schiele for dissecting the trap nests and needling the emerging individuals, Rainer Theunert for reassurance of species identities, Jochen Fründ for statistical advice and help with species identification, Ines Vollhardt and Jeroen Everaars for help with the experimental site selection and support during the field work and Katrin Schmon for helping sorting the insects caught in the pan traps. Furthermore, we thank two anonymous reviewers for providing helpful comments to improve this manuscript. This research was funded by the Helmholtz Association (VHNG-247). 


\section{REFERENCES}

Aickin, M. \& Gensler, H. (1996) Adjusting for multiple testing when reporting research results: The Bonferroni vs Holm methods. American Journal of Public Health, 86, 726-728.

Albrecht, M., Duelli, P., Müller, C., Kleijn, D. \& Schmid, B. (2007) The Swiss agrienvironment scheme enhances pollinator diversity and plant reproductive success in nearby intensively managed farmland. Journal of Applied Ecology, 44, 813-822.

Alofs, K.M. \& Fowler, N.L. (2010) Habitat fragmentation caused by woody plant encroachment inhibits the spread of an invasive grass. Journal of Applied Ecology, 47, 338-347.

Beier, P. \& Noss, R.F. (1998) Do habitat corridors provide connectivity? Conservation Biology, 12, 1241-1252.

Bellmann, H. (2005) Bienen, Wespen, Ameisen, Hautflügler Mitteleuropas. Zweite Auflage. Franckh-Kosmos Verlags-GmbH \& Co. KG, Stuttgart, Germany.

Benton, TG., Vickery, J.A. \& Wilson, J.D. (2003) Farmland biodiversity: is habitat heterogeneity the key? Trends in Ecology and Evolution, 18, 182-188.

Biesmeijer, J.C., Roberts, S.P.M., Reemer, M., Ohlemüller, R., Edwards, M., Peeters, T., Schaffers, A.P., Potts, S.G., Kleukers, R., Thomas, C.D., Settele, J. \& Kunin, W.E. (2006) Parallel declines in pollinators and insect-pollinated plants in Britain and the Netherlands. Science, 313, 351-354.

Brambilla, M., Rubolini, D. \& Guidali, F. (2007) Between land abandonment and agricultural intensification: habitat preferences of Red-backed Shrikes (Lanius collurio) in low-intensity farming conditions. Bird Study, 54, 160-167.

Brown, M.J.F. \& Paxton, R.J. (2009) The conservation of bees: a global perspective. 
Apidologie, 40, 410-416.

Budriené, A. (2003) Prey of Symmorphus wasps (Hymenoptera: Eumeninae) in Lithuania. Acta Zoologica Lituanica, 13, 306-310.

Cane, J.H. (1997) Ground nesting bees: the neglected pollinator resource for agriculture. Acta Horticulturae, 437, 309-324.

Collinge, S.K. (2000) Effects of grassland fragmentation on insect species loss, colonization, and movement patterns. Ecology, 81, 2211-2226.

Crawley, M.J. (2007) The R Book. John Wiley \& Sons Ltd, Chichester, UK.

Curry, J.P. (1994) Grassland Invertebrates: Ecology, influence on soil fertility and effects on plant growth. Chapman \& Hall, London, UK.

Damschen, E.I., Haddad, N.M., Orrock, J.L., Tewksbury, J J. \& Levey, D.J. (2006) Corridors increase plant species richness at large scales. Science, 313, $1284-1286$.

Danks, H. V. (1970) Biology of some stem-nesting aculeate Hymenoptera. Transactions of the Royal Entomological Society of London, 122, 323-395.

De la Rua, P., Jaffe, R., Dall'Olio, R., Munoz, I. \& Serrano, J. (2009) Biodiversity, conservation and current threats to European honeybees. Apidologie, 40, 263-284.

Dover, J.W. \& Fry, G.L.A. (2001) Experimental simulation of some visual and physical components of a hedge and the effects on butterfly behaviour in an agricultural landscape. Entomologia Experimentalis et Applicata, 100, 221-233.

Downey, D.L. \& Winston, M.L. (2001) Honey bee colony mortality and productivity with single and dual infestations of parasitic mite species. Apidologie, 32, 
$567-575$.

Fahrig, L. (2003) Effects of habitat fragmentation on biodiversity. Annual Review of Ecology, Evolution and Systematics, 34, 487-515.

Freemark, K.E., Boutin, C. \& Keddy, C.J. (2002) Importance of farmland habitats for conservation of plant species. Conservation Biology, 16, 399-412.

Fry, G.L.A. (1995) Landscape ecology of insect movement in arable ecosystems. Ecology and integrated farming systems (eds D.A. Glen, M.P. Greaves \& H.M. Anderson), pp. 177-202. Wiley, Chichester, UK.

Gathmann, A., Greiler, H.J. \& Tscharntke, T., (1994) Trap-nesting bees and wasps colonizing set-aside fields: Succession and body-size, management by cutting and sowing. Oecologia, 98, 8-14.

Gathmann, A. \& Tscharntke, T. (2002) Foraging ranges of solitary bees. Journal of Animal Ecology, 71, 757-764.

Goulson, D., Hanley, M.E., Darvill, B. \& Ellis, J.S. (2006) Biotope associations and the decline of bumblebees (Bombus spp.). Journal of Insect Conservation, 10, 95-103.

Greenleaf, S.S., Williams, N.M., Winfree, R. \& Kremen, C. (2007) Bee foraging ranges and their relationship to body size. Oecologia, 153, 589-596.

Haddad, N.M., Bowne, D.R., Cunningham, A., Danielson, B.J., Levey, D.J., Sargent, S., \& Spira, T. (2003) Corridor use by diverse taxa. Ecology, 84, 609-615.

Haddad, N.M. \& Tewksbury, J.J. (2005) Low-quality habitat corridors as movement conduits for two butterfly species. Ecological Applications, 15, 250-257.

Hannon, L.E. \& Sisk, T.D. (2009) Hedgerows in an agri-natural landscape: Potential habitat value for wild bees. Biological Conservation, 142, 2140-2154. 
Holzschuh, A., Steffan-Dewenter, I. \& Tscharntke, T. (2009) Grass strip corridors in agricultural landscapes enhance nest-site colonization by solitary wasps. Ecological Applications, 19, 123-132.

Holzschuh, A., Steffan-Dewenter, I. \& Tscharntke, T. (2010) How do landscape composition and configuration, organic farming and fallow strips affect the diversity of bees, wasps and their parasitoids? Journal of Animal Ecology, 79, 491-500.

Holt, R.D., Lawton, J.H., Polis, G.A. \& Martinez, N.D. (1999) Trophic rank and the species-area relationship. Ecology, 80, 1495-1504.

Hothorn, T., Bretz, F. \& Westfall, P. (2008) Simultaneous Inference in General Parametric Models. Biometrical Journal, 50, 346-363.

Kells, A.R. \& Goulson, D. (2003) Preferred nesting sites of bumblebee queens (Hymenoptera: Apidae) in agroecosystems in the UK. Biological Conservation, 109, 165-174.

Klein A.M., Vaissière B.E., Cane J.H., Steffan-Dewenter I., Cunningham S.A., Kremen C. \& Tscharntke T. (2007) Importance of pollinators in changing landscapes for world crops. Proceedings of the Royal Society B - Biological Sciences, 274, 303-313.

Knight, M.E., Osborne, J.L., Sanderson, R.A., Hale, R.J., Martin, A.P. \& Goulson, D. (2009) Bumblebee nest density and the scale of available forage in arable landscapes. Insect Conservation and Diversity, 2, 116-124.

Kremen, C., Williams, N.M. \& Thorp, R.W. (2002) Crop pollination from wild bees at risk from agricultural intensification. Proceedings of the National Academy of Scienes of the United States of America, 99, 16812-16816.

Kuefler, D., Hudgens, B., Haddad, N.M., Morris, W.F. \& Thurgate, N. (2010) The conflicting role of matrix habitats as conduits and barriers for dispersal. 
Ecology, 91, 944-950.

Larsen, T.H., Williams, N.M. \& Kremen, C. (2005) Extinction order and altered community structure rapidly disrupt ecosystem functioning. Ecology Letters, 8, $538-547$.

Mauremooto, J.R., Wratten, S.D., Worner, S.P. \& Fry, G L.A. (1995) Permeability of hedgerows to predatory carabid beetles. Agriculture, Ecosystems and Environment, 52, 141-148.

Michel, N., Burel, F., Legendre, P. \& Butet, A. (2007) Role of habitat and landscape in structuring small mammal assemblages in hedgerow networks of contrasted farming landscapes in Brittany, France. Landscape Ecology, 22, 1241-1253.

Öckinger, E. \& Smith, H.G. (2007) Semi-natural grasslands as population sources for pollinating insects in agricultural landscapes. Journal of Applied Ecology, 44, $50-59$.

Pinheiro, J., Bates, D., DebRoy, S., Sarkar, D \& the R Development Core Team (2009) nlme: Linear and Nonlinear Mixed Effects Models. R package version 3.1-96.

Pollard, K.A. \& Holland, J.M. (2006) Arthropods within the woody element of hedgerows and their distribution pattern. Agricultural and Forest Entomology, 8, 203-211.

Potts S.G., Roberts S.P.M., Dean R., Marris G., Brown M., Jones R. \& Settele J. (2010) Declines of managed honeybees and beekeepers in Europe. Journal of Apicultural Research, 49, 15-22.

Proches, S., Wilson, J.R.U., Veldtman, R., Kalwij, J.M., Richardson, D.M. \& Chown, S.L. (2005) Landscape corridors: Possible dangers? Science, 310, 779.

R Development Core Team (2009) A Language and Environment for Statistical Computing, $\mathrm{R}$ Foundation for Statistical Computing, Vienna, Austria. 
Available at: http://www.R-project.org (accessed 21 Aug 2010).

Ricketts, T.H., Regetz, J., Steffan-Dewenter, I., Cunningham, S.A., Kremen, C., Bogdanski, A., Gemmill-Herren, B., Greenleaf, S.S., Klein, A.M., Mayfield, M.M., Morandin, L.A., Ochieng, A. \& Viana, B.F. (2008) Landscape effects on crop pollination services: are there general patterns? Ecology Letters, 11, $499-515$.

Rosenberg, D.K., Noon, B.R. \& Meslow, E.C. (1997) Biological corridors: Form, function, and efficacy. Bioscience, 47, 677-687.

Saunders, D.A., Hobbs, R.J. \& Margules, C.R. (1991) Biological consequences of ecosystem fragmentation - a review. Conservation Biology, 5, 18-32.

Schmid-Egger, C. (2004) Bestimmungsschlüssel für die deutschen Arten der solitären Faltenwespen (Hymenoptera: Eumeninae). DJN, Hamburg, Germany.

Schmidt, M.H. \& Tscharntke, T. (2005) Landscape context of sheetweb spider (Araneae : Linyphiidae) abundance in cereal fields. Journal of Biogeography, 32, 467-473.

Steffan-Dewenter, I. \& Tscharntke, T. (1999) Effects of habitat isolation on pollinator communities and seed set. Oecologia, 121, 432-440.

Steffan-Dewenter, I. (2003) Importance of habitat area and landscape context for species richness of bees and wasps in fragmented orchard meadows. Conservation Biology, 17, 1036-1044.

Steffan-Dewenter, I., Potts, S.G. \& Packer, L. (2005) Pollinator diversity and crop pollination services are at risk. Trends in Ecology and Evolution, 20, 651-652.

Sutcliffe, O.L. \& Thomas, C.D. (1996) Open corridors appear to facilitate dispersal by ringlet butterflies (Aphantopus hyperantus) between woodland clearings. Conservation Biology, 10, 1359-1365. 
Tewksbury, J.J., Levey, D.J., Haddad, N.M., Sargent, S., Orrock, J.L., Weldon, A., Danielson, B.J., Brinkerhoff, J., Damschen, E.I. \& Townsend, P. (2002) Corridors affect plants, animals, and their interactions in fragmented landscapes. Proceedings of the National Academy of Scienes of the United States of America, 99, 12923-12926.

Thomas, C.F.G. \& Jepson, P.C. (1997) Field-scale effects of farming practices on linyphiid spider populations in grass and cereals. Entomologia Experimentalis et Applicata, 84, 59-69.

Tilman, D., Fargione, J., Wolff, B., D'Antonio, C., Dobson, A., Howarth, R., Schindler, D., Schlesinger, W.H., Simberloff, D. \& Swackhamer, D. (2001) Forecasting agriculturally driven global environmental change. Science, 292, 281-284.

Townsend, P.A. \& Levey, D.J. (2005) An experimental test of whether habitat corridors affect pollen transfer. Ecology, 86, 466-475.

Tscharntke, T., Gathmann, A. \& Steffan-Dewenter, I. (1998) Bioindication using trapnesting bees and wasps and their natural enemies: community structure and interactions. Journal of Applied Ecology, 35, 708-719.

Tscharntke, T. \& Brandl, R. (2004) Plant-insect interactions in fragmented landscapes. Annual Review of Entomology, 49, 405-430.

Tylianakis, J.M., Klein, A.M. \& Tscharntke, T. (2005) Spatiotemporal variation in the diversity of hymenoptera across a tropical habitat gradient. Ecology, 86, 3296-3302.

Tylianakis, J.M., Tscharntke, T. \& Klein, A.M., 2006. Diversity, ecosystem function, and stability of parasitoid host interactions across a tropical habitat gradient. Ecology, 87, 3047-3057.

Varchola, J.M. \& Dunn, J.P. (2001) Influence of hedgerow and grassy field borders on ground beetle (Coleoptera: Carabidae) activity in fields of corn. Agriculture, 
Ecosystems and Environment, 83, 153-163.

WallisDeVries, M.F., Poschlod, P. \& Willems, J.H. (2002) Challenges for the conservation of calcareous grasslands in northwestern Europe: integrating the requirements of flora and fauna. Biological Conservation, 104, 265-273.

Watanabe, M.E. (1994) Pollination worries rise as honey-bees decline. Science, 265, $1170-1170$.

Westphal, C., Steffan-Dewenter, I. \& Tscharntke, T. (2006) Bumblebees experience landscapes at different spatial scales: possible implications for coexistence. Oecologia, 149, 289-300.

Westphal, C., Bommarco, R., Carre, G., Lamborn, E., Morison, N., Petanidou, T., Potts, S.G., Roberts, S.P.M., Szentgyorgyi, H., Tscheulin, T., Vaissiere, B.E., Woyciechowski, M., Biesmeijer, J.C., Kunin, W.E., Settele, J. \& SteffanDewenter, I. (2008) Measuring bee diversity in different European habitats and biogeographical regions. Ecological Monographs, 78, 653-671.

Winfree, R., Williams, N.M., Dushoff, J. \& Kremen, C. (2007) Native bees provide insurance against ongoing honey bee losses. Ecology Letters, 10, 1105-1113.

Winfree, R., Aguilar, R., Vazquez, D.P., LeBuhn, G. \& Aizen, M.A. (2009) A metaanalysis of bees' responses to anthropogenic disturbance. Ecology, 90, $2068-2076$.

Zurbuchen, A., Bachofen, C., Müller, A., Hein, S. \& Dorn, S. (2010) Are landscape structures insurmountable barriers for foraging bees? A mark-recapture study with two solitary pollen specialist species. Apidologie, 41, 497-508. 


\section{APPENDIX}

A2.1 Survey of bee genera caught in the pan traps.

\begin{tabular}{lc} 
Genera & $\begin{array}{c}\text { No. of } \\
\text { individuals }\end{array}$ \\
\hline Bombus & 203 \\
Andrena & 27 \\
Chelostoma & 5 \\
Halictus & 10 \\
Hylaeus & 16 \\
Lasioglossum & 211 \\
Megachile & 5 \\
Panurgus & 1 \\
Sphecodes & 9 \\
Stelis & 1 \\
Sum & $\mathbf{4 8 8}$ \\
\hline
\end{tabular}

A2.2 Results of the linear mixed-effect model with site as random factor, testing the connected and unconnected strip in $100 \mathrm{~m}$ distance in terms of abundance and species richness for the functional groups of wasps (Predators of lepidopteran larvae, predators of spiders and predators of aphids). Predators of chrysomelid larvae are excluded, because sample size on the grass strips was too low.

\begin{tabular}{lcccc} 
& \multicolumn{2}{c}{ Abundance } & \multicolumn{2}{c}{ Species richness } \\
& $\mathrm{F}_{1,4}$ & $\mathrm{P}$ & $\mathrm{F}_{1,4}$ & $\mathrm{P}$ \\
& 0.55 & 0.500 & 0.230 & 0.660 \\
Predators of lepidopteran larvae & 0.086 & 0.784 & 0.134 & 0.733 \\
Predators of spiders & 0.228 & 0.660 & 0.500 & 0.520 \\
Predators of aphids & & & & \\
\hline
\end{tabular}


A2.3 Survey of individuals occupying the trap-nests. Prey of predatory wasps, parasitism rates, and parasitoids found in the nests of all genera are included.

\section{No. brood parasitized parasitism Parasitoids}

\section{Trap-nesting}

bees

Chelostoma

196

34

Heriades

Hylaeus

Megachile

90

18

25

872

12

24

Osmia

Sum

\section{Trap-nesting} wasps

Ancistrocerus Lepidopteran larvae

Auplopus

Spiders

Crossocerus

Diptera

Dipogon

Spiders

Discoelius

Lepidopteran larvae

Eumenidae sp. Lepidopteran larvae

Nitela

Diptera

Passaloecus

Aphids

Pemphredon

Aphids

Psenulus

Aphids

Spilomena

Thysanoptera

Symmorphus

Chrysomelid larvae

Trypoxylon

Spiders
17.35 Stelis minuta, Trichrysis cyanea, Sapyga clavicornis, Melittobia acasta, Ichneumonidae

10.26 Sapyga decemguttata, Stelis spp.

5.05 Gasteruption assectator, Gasteruption jaculator, Melittobia acasta, Ichneumonidae

20.00 Coelioxys mandibularis, Coelioxys inermis, Melittobia acasta, Ichneumonidae Melittobia acasta

Sum

5.48

0.00

13.73 Melittobia acasta, Megatoma undata

6.45 Chrysis spp.

0.00

28.14 Chrysis ignita, Melittobia acasta, Ichneumonidae,

12.50 Melittobia acasta

6.10 Melittobia acasta, Trichrysis cyanea, Omalus aeneus

0.00

0.00

6.98

34.45

Chrysis ignita, Melittobia acasta

Melittobia acasta, Trichrysis cyanea, Ichneumonidae 
CHAPTER

3

\section{BEE DIVERSITY AND FALLOW LOSS ACROSS AGRICULTURAL}

\section{LANDSCAPES AND YEARS}

Kristin M. Krewenka, Andrea Holzschuh, David J. Gladbach, Teja Tscharntke \& Carsten F. Dormann

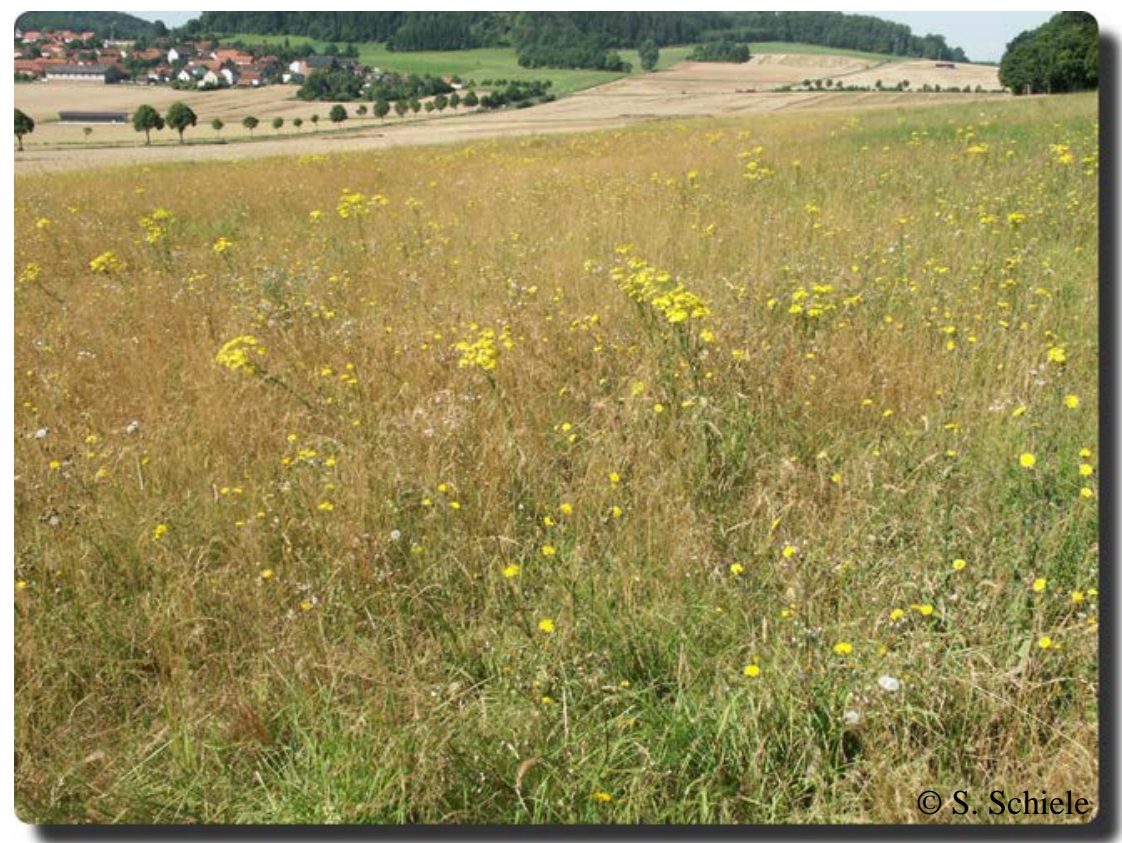

submitted in: Journal of Applied Ecology, May 2011 


\section{ABSTRACT}

1. Pollinators in the agricultural landscape have gained growing attention, since pollination is crucial for two thirds of the world's crops. However, landscape simplification, including loss of fallows due to changed EU policy, can be hypothesized to cause pollinator declines.

2. In this study we sampled native bee populations using pan traps and trap nests in the agricultural landscape over three years (2006-2008) in five different habitat types along a gradient of landscape complexity in Lower Saxony, Germany. We analyzed the relative role of habitat and landscape attributes on the abundance and species richness of native bees using hierarchical partitioning.

3. Following the discontinuation of EU subsidies for fallows in 2006, the amount of fallows declined by $59 \%$ in 2008. Abundance of bumblebees decreased by $85 \%$ and their species richness by $65 \%$, while abundance of solitary groundnesting bees declined by $32 \%$ and their species richness by $35 \%$ in our study sites in synchrony.

4. Abundance of bumblebees was positively related to the amount of fallow in the landscape, while species richness of bumblebees and abundance and species richness of solitary ground-nesting bees was positively influenced by the amount of semi-natural habitats. Abundance and species richness of aboveground nesting bees remained stable from 2007 to 2008 and their abundance and species richness was most influenced by habitat type.

5. Our results show that the decline of fallows and semi-natural habitats was related to reduced abundance and species richness of wild bees. The abolition of fallows by the EU affected mainly bumblebees, which are major pollinators in agricultural landscapes. The current EU scheme of cross-compliance does not mitigate the negative impact of fallow loss, jeopardizing pollination services in the agricultural landscape. Hence there is a need to add conservation measures enhancing functional biodiversity to cross-compliance.

\section{KEY WORDS}

Biodiversity, fallows, habitat type, hierarchical partitioning, wild bees 


\section{INTRODUCTION}

The world population is growing and so is the demand for food (Rosegrant \& Cline 2003; Godfray et al. 2010). Models predict a mounting need for agricultural production units, which may result in more natural habitat converted into arable land. In the last decades the intensification of agricultural practises and the associated increasing production area have led to a severe decline of biodiversity and abundance of many organisms in the agricultural landscape (Tilman et al. 2001; Benton, Vickery \& Wilson 2003). The main reasons are the destruction and fragmentation of natural habitats and the use of pesticides, herbicides and fertilizers, leading to a species-poor environment and endangering ecosystem services provided by arthropods such as biological control or pollination (Landis et al. 2008; Kremen, Williams \& Thorp 2002). Detrimental effects of agricultural intensification and habitat fragmentation on wild bee communities have been documented (Steffan-Dewenter 2003; Holzschuh et al. 2007). Bees are the most efficient animal pollinators in the northern hemisphere and their survival is crucial for the pollination of most wild plants and crops (Ingram, Nabhan \& Buchmann 1996; Daily et al. 1997; Nabhan \& Buchmann 1997; Winfree et al. 2007). Many rosaceous plants, legumes and oilseeds are relying on insect pollination for developing fruits and produce optimal yields (Corbet 1987; Klein et al. 2007). The decline of pollinators and the absence of pollination services may result in high economic losses (Losey \& Vaughan 2006; Gallai et al. 2009).

Maintaining wild bee populations in the agricultural landscapes requires provision of an adequate supply of food and nesting resources (Banaszak 1992; Westrich 1996). These are offered by semi-natural habitats, such as extensively used grasslands, hedges and orchard meadows (Steffan-Dewenter 2003; Öckinger \& Smith 2007). Previous studies found that wild bee communities profit particularly from fallows in the landscape (Corbet 1995; Tscharntke et al. 1996; Steffan-Dewenter \& Tscharntke 2001).

In 1992 the EU established a set-aside program combining economical and ecological demands. On one hand this policy was an instrument for avoiding overproduction, leading to price corruption, on the other hand the fallows served as additional habitats for many species. Subsidies were paid to farmers, who set fields aside and converted them into fallows. In 2007 and 2008 the prices for crops on the global market reached a peak, questioning global food security (FAO 2006, 2007; 
Statistisches Bundesamt, Germany 2010). The EU decided to abolish the set-aside fields, reacting to the inquiries of the market (ENCA 2008). In response to the policy change, conversion of fallows into crop fields or intensive pastures for livestock feeding took place, resulting in reduced biodiversity in the landscapes as predicted by Stoate et al. (2009). We aimed at evaluating the implications of this policy on pollinators in the agricultural landscape.

In this study we used a large scale approach, monitoring wild bee populations in five habitat types in 12 differentially structured landscapes over a period of three years to elucidate the impact of habitat types and landscape complexity on wild bee populations in the agricultural landscape and we paid particular attention to the decrease of fallows in the landscape over three years.

Our study is the first to combine landscape and local factors and their influence on abundance and species richness of wild bees in the agricultural landscape over a time span of three years, using hierarchical partitioning. The method of hierarchical partitioning accounts for multicollinearity among predictors and estimates their independent contribution to explaining variation of variables (Chevan \& Sutherland 1991; Mac Nally 1996). Our aim was to assess (i) the impact of landscape attributes, namely the amount of arable land, the amount of fallows and the amount of seminatural habitats in the landscape, as well as (ii) the importance of habitat types for bee populations in the agricultural landscape. Further we assumed that (iii) the hypothesized fallow loss has negative effects on the abundance and species richness of solitary ground-nesting bees, bumblebees and above ground-nesting bees. 


\section{MATERIALS AND METHODS}

\section{STUDY SITE}

The study was conducted in the years 2006, 2007 and 2008 in 12 differentially structured landscapes (study areas) in the vicinity of Göttingen, Lower Saxony, Germany (Thies \& Tschantke 1999). Landscape complexity was measured as amount of arable land, which was negatively correlated with Shannon diversity of habitat types in the landscape (Pearson product-moment correlation: $r_{p}=-0.84, \mathrm{P}<0.001$, $n=60$ ). The twelve landscapes varied from structurally complex (12\% arable land) to structurally simple (89\% of arable land). We chose five different habitat types as study sites within each landscape: i) winter wheat field, ii) grassy field margin strip, adjacent to the wheat field, iii) fallow, iv) meadow and v) forest edge, which are typical for our agricultural landscapes. Wheat field and meadow were conventionally managed.

\section{DATA COLLECTION}

In total we installed 180 pan traps to sample foraging ground-nesting bees. One set of pan traps was placed in the centre of each habitat type in each landscape and consisted of three plastic bowls, sprayed with UV-reflecting colour in white, yellow and blue (Westphal et al. 2008). Each of the bowls was fixed on a wooden pole and adjusted to the vegetation height on the focal habitat at exposure date. To avoid interference of the different coloured pan traps, they were aligned with $10 \mathrm{~m}$ distance to each other and active for one week: three times in June and July, one time after harvest in August. Pan traps contained $500 \mathrm{ml}$ water and ethylene glycol in a 2:1 ratio plus a drop of detergent (to reduce surface tension). Additionally we installed two sets of trap nests in each habitat type (15 $\mathrm{m}$ from the outer pan traps) to account for above ground-nesting bees in the years 2007 and 2008. One set consisted of two plastic tubes (diameter $12.5 \mathrm{~cm}$ ), filled with approximately 200 reed internodes (diameter $0.2-1 \mathrm{~cm}$ ) to serve as nesting device for above ground-nesting bee species. The two trap nests were fixed on a wooden pole in a height of $1.20 \mathrm{~m}$. In total these were 240 trap nests. They were exposed from the second week of April until the end of July, when we had to remove them because of harvest in crop fields, in both years. In 2008 the fallow we used as trap location was removed in one landscape and in the surrounding landscape we did not find an alternative fallow, therefore the number of pan traps was reduced to 177 and the number of trap nests to 236 in that year. 
Wild bees caught in the pan traps were sorted and identified to species level. We excluded individuals of the domesticated honeybee (Apis mellifera) from analyses. Occupied internodes of the trap nests were dissected in the lab and the number of brood cells recorded. The single internodes were stored four weeks in glass vials at $4^{\circ}$ Celsius to stimulate larval development and after that kept at room temperature. After the adult individuals emerged they were identified to species level.

Landscape attributes were mapped within a radius of $1000 \mathrm{~m}$ around each habitat/trap location in the twelve landscapes and digitalized, using ArcView 3.2 (ESRI). Landscape attributes were the amount of arable land (intensively used crop fields), the amount of fallows and the amount of semi natural habitats (calcareous grasslands, orchard meadows, shrubs, hedges and embankment) in the surrounding landscape. The species richness of flowering herbs and shrubs on the habitat types was estimated on each trap location in 15 randomized $2 \times 2 \mathrm{~m}$ plots. Wheat fields hosted significantly lower numbers of plant species than the other habitats, while forest edges comprised the highest numbers of flowering plant species (lme: $F_{4,43}$ $=14.110, \mathrm{P}<0.001$ ) (see Appendix, A3.1). The flower cover of the study sites was estimated at the start of the pan trap rounds (four times from June to August), following the Braun-Blanquet method. We did not find significant differences in flower cover for the habitat types (lme: $\mathrm{F}_{4,43}=2.08201, \mathrm{P}=0.100$ ).

\section{STATISTICAL ANALYSES}

We divided the bees caught into three groups to account for differences in life-history traits (Westrich 1989). These were i) solitary ground-nesting bees, ii) bumblebees and iii) above ground-nesting bees. Ground-nesting and above ground-nesting bees have different requirements concerning nesting facilities and may be influenced by different landscape features. To differentiate between the social bumblebees and the other ground-nesting bees, we refer to the latter as solitary ground-nesting bees, including primitively social bees such as species belonging to the genera Lasioglossum and Halictus.

The statistical analyses were conducted using $\mathrm{R}$ (version 2.11.1; $\mathrm{R}$ Development Core Team, 2010). The landscape attributes were highly inter-correlated (see Appendix, A3.2), making it difficult to disentangle possible effects of single attributes on pollinator abundance and species richness. We therefore used the method of hierarchical partitioning (Chevan \& Sutherland 1991; McNally 1996, 2000), as 
solution for dealing with multi-collinearity in data sets. The independent effects of each variable are calculated by implementing multivariate regressions with all possible combinations of variables. Recent studies by Heikkinen et al. (2004, 2005) and Teodoro, Klein \& Tscharntke (2008) used this method to assess the impact of environmental variables on distribution patterns of butterflies and crop pest organisms. Olea, Mateo-Tomás \& de Frutos (2010) emphasize the suitability of this method for ecological research. We conducted hierarchical partitioning to calculate the contribution of study sites and landscape attributes on the abundance and species richness of the three bee groups using the R-package "hier.part" (Walsh \& Mc Nally 2008). Species richness is the total number of species per study site for each study area, abundances in pan traps are the sums of caught individuals for each study site in each study area, respectively. Abundance in trap nests are the total number of brood cells per study site in each study area. Abundance and species richness were $\log _{10^{-}}$ transformed and landscape attributes were arcsine square root transformed to meet the assumption of well-distributed residuals (Crawley 2007). Temporal effects of year were checked with linear mixed-effects models (lmes), employing the package "nlme" (Pinheiro et al. 2009). Lmes comprised landscape attributes, abundances and species richness of wild bees as dependent variable, year as explanatory variable and site as random factor, to account for the nested design of the experiment. To test for the effects of variables, deriving from the hierarchical partitioning, lmes with abundance and species richness of bees as dependent variable and landscape attributes and study sites as explanatory variables, including interaction of both, and study areas as random factor were conducted. Since the variable year was highly confounded with landscape attributes (especially amount of fallow) and bee abundance and species richness (see Fig. 3.1), we excluded it from the lmes. Models were fitted using simple stepwise regression with AIC (Akaike's Information Criterion) as indicator for the best fitted model. Resulting p-values were adjusted, using the Tukey's-HSD test. We excluded the above ground-nesting red mason bee (Osmia rufa) from analyses, since its abundance was nearly ten times higher in 2008 than 2007 due to extreme weather changes in both years during their main flight time in May. Steffan-Dewenter (1998) found that occupation rates of this common bee species are not related to isolation from semi-natural habitats and we assumed that the high abundances in 2008 could blur possible effects of study sites and landscape attributes. 


\section{RESULTS}

In total we recorded 2050 solitary ground-nesting bees belonging to 57 species, with the main genera Lasioglossum (44.45 \%), Andrena (35.55 \%) and Halictus (10.52 \%) and 3030 bumblebees of 20 species (including Psythirus spp.) during the three studying years. 1378 brood cells were built by 15 above ground-nesting bee species in the years 2007 and 2008 in the trap nests, the genera Hylaeus (38.95 \%) and Megachile (33.26 \%) being most abundant.

\section{FALLOW AND ABUNDANCE AND SPECIES LOSS OVER THE YEARS}

The proportion of fallows within landscapes declined over $59 \%$ in the twelve landscapes from 2006 to 2008 (Table 3.1, Fig. 3.1a). In the same period of time abundance and species richness of solitary ground-nesting bees and bumblebees also declined (Table 3.2, Fig. 3.1b, 3.1c). Above ground-nesting bees showed a contrasting pattern to the ground-nesting bees. We found no difference in abundance and species richness of above ground-nesting bees between 2007 and 2008 (Table 3.2, Fig. 3.1d).

a)

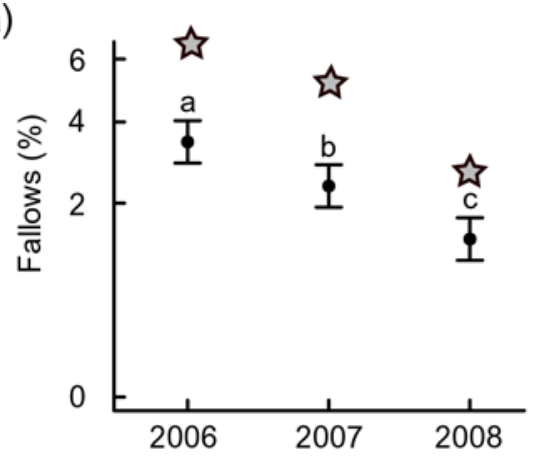

c)

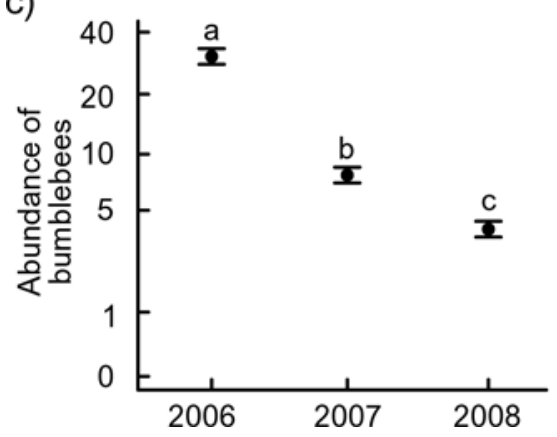

b)

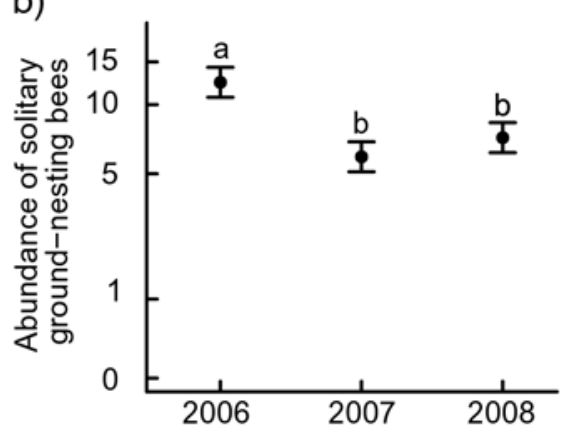

d)

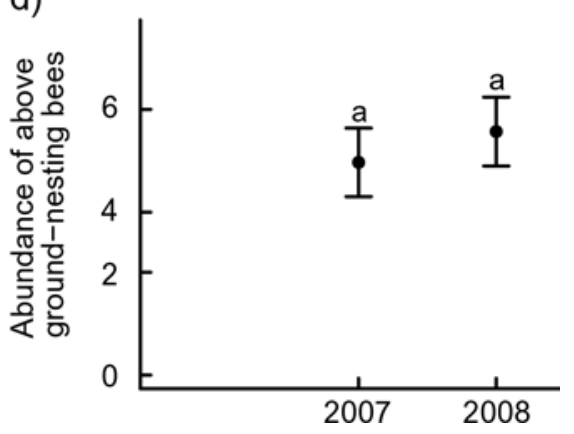

Figure 3.1 a) Amount of fallows (\%) and abundances of b) solitary ground-nesting bees, c) bumblebees and d) above ground-nesting bees over the years. Given are the mean values \pm SEM, P-values were adjusted using the Tukey's HSD test. The grey stars in a) show the changes in fallows (\%) for Germany (Statistisches Bundesamt, 2010). 
Table 3.1 Landscape attributes in the years 2006-2008 and averaged climate characteristics (Wetterstation Göttingen) for the months April-August.

\begin{tabular}{|c|c|c|c|c|c|c|c|c|c|}
\hline \multirow[t]{2}{*}{ Year } & \multicolumn{3}{|c|}{2006} & \multicolumn{3}{|c|}{2007} & \multicolumn{3}{|c|}{2008} \\
\hline & Mean \pm SEM & Min. & Max. & Mean \pm SEM & Min. & Max. & Mean \pm SEM & Min. & Max. \\
\hline Amount arable land (\%) & $49.36 \pm 2.72$ & 12.24 & 88.13 & $52.62 \pm 2.79$ & 17.46 & 89.53 & $50.48 \pm 2.87$ & 18.46 & 87.86 \\
\hline Amount fallows (\%) & $4.12 \pm 0.53$ & 0.69 & 17.72 & $2.92 \pm 0.36$ & 0.04 & 14.40 & $1.69 \pm 2.87$ & 0 & 7.47 \\
\hline $\begin{array}{l}\text { Amount semi-natural } \\
\text { habitats (\%) }\end{array}$ & $3.20 \pm 0.27$ & 0.16 & 11.4 & $2.59 \pm 0.22$ & 0.16 & 8.24 & $1.83 \pm 0.19$ & 0.12 & 8.35 \\
\hline Mean precipitation (mm) & \multicolumn{3}{|c|}{86.62} & \multicolumn{3}{|c|}{91.62} & \multicolumn{3}{|c|}{52.62} \\
\hline Mean temperature ( C) & \multicolumn{3}{|c|}{15.06} & \multicolumn{3}{|c|}{15.32} & \multicolumn{3}{|c|}{15.06} \\
\hline Sunshine duration (h) & \multicolumn{3}{|c|}{232.62} & \multicolumn{3}{|c|}{229.1} & \multicolumn{3}{|c|}{214.42} \\
\hline
\end{tabular}

Table 3.2 Abundance and species richness of solitary ground-nesting bees, bumblebees and above ground-nesting bees, over the years. P-values were adjusted, using Tukey's HSD test.

\begin{tabular}{|c|c|c|c|c|c|c|}
\hline & \multicolumn{2}{|c|}{$\begin{array}{l}\text { Solitary ground- } \\
\text { nesting bees }\end{array}$} & \multicolumn{2}{|c|}{ Bumblebees } & \multicolumn{2}{|c|}{$\begin{array}{l}\text { Above ground- } \\
\text { nesting bees }\end{array}$} \\
\hline & $\mathrm{F}_{2,165}$ & $\mathrm{P}$ & $\mathrm{F}_{2,165}$ & $\mathrm{P}$ & $\mathrm{F}_{1,106}$ & $\mathrm{P}$ \\
\hline Abundance & 15.24 & $<0.001$ & 130.04 & $<0.001$ & 0.61 & 0.440 \\
\hline $2006-2008$ & & $<0.001$ & & $<0.001$ & & \\
\hline 2006 - 2007 & & $<0.001$ & & $<0.001$ & & \\
\hline $2007-2008$ & & 0.362 & & $<0.001$ & & \\
\hline Species richness & 24.86 & $<0.001$ & 84.18 & $<0.001$ & 0.87 & 0.353 \\
\hline $2006-2008$ & & $<0.001$ & & $<0.001$ & & \\
\hline $2006-2007$ & & $<0.001$ & & $<0.001$ & & \\
\hline $2007-2008$ & & 0.122 & & $<0.001$ & & \\
\hline
\end{tabular}

\section{HIERARCHICAL PARTITIONING ANALYSIS}

Abundance and species richness of solitary ground-nesting bees were mainly influenced by the amount of semi-natural habitats in the landscape, contributing $72 \%$ to abundance and $82 \%$ to species richness (Fig. 3.2a and Fig. 3.2b).

The amount of fallows in the landscape contributed with $46 \%$ to abundance of bumblebees, followed by the amount of semi-natural habitats with $37 \%$. The species richness was affected by the amount of semi natural habitats on the first rank (54\%) and the amount of fallows with $23 \%$ on the second (Fig. 3.2c and Fig. 3.2d). 
Abundance of the above ground-nesting bees was mainly influenced by study site (62\%), followed by the amount of semi natural habitats in the landscape (31\%), while the effect of study site on the species richness was even stronger counting $81 \%$ (Fig. 3.2e and Fig. 3.2f) (see Appendix, A3.3)
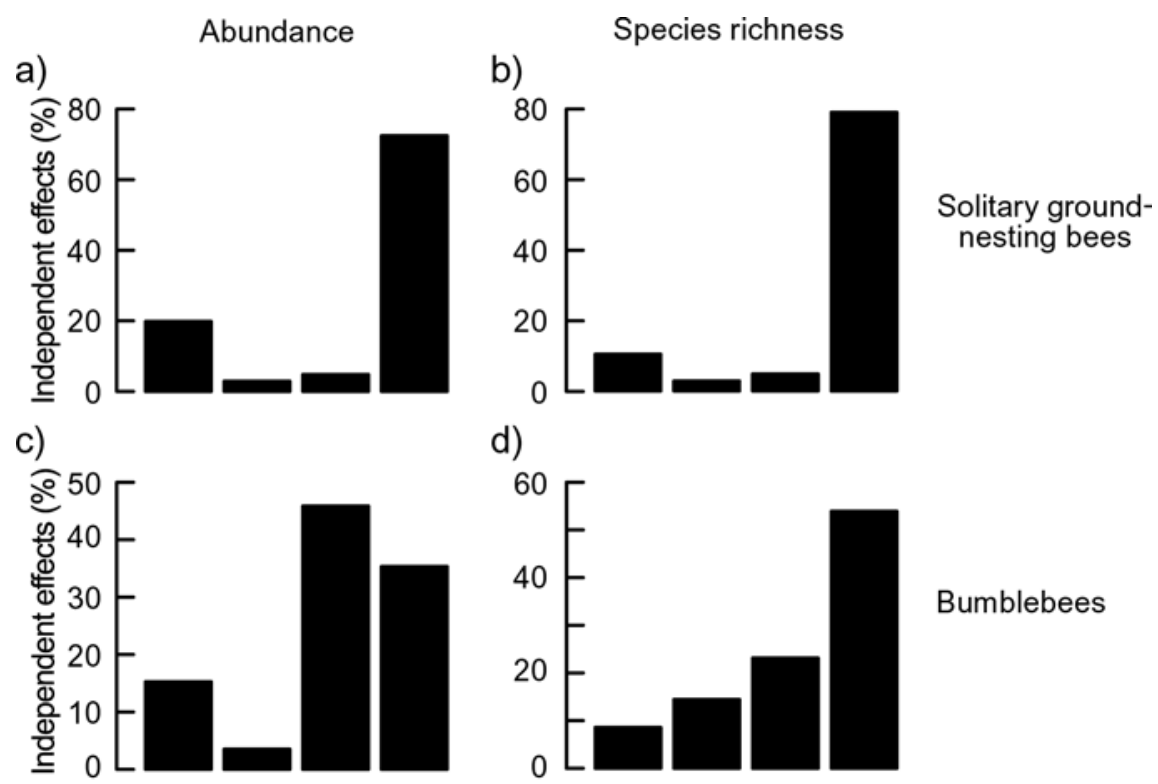

d)
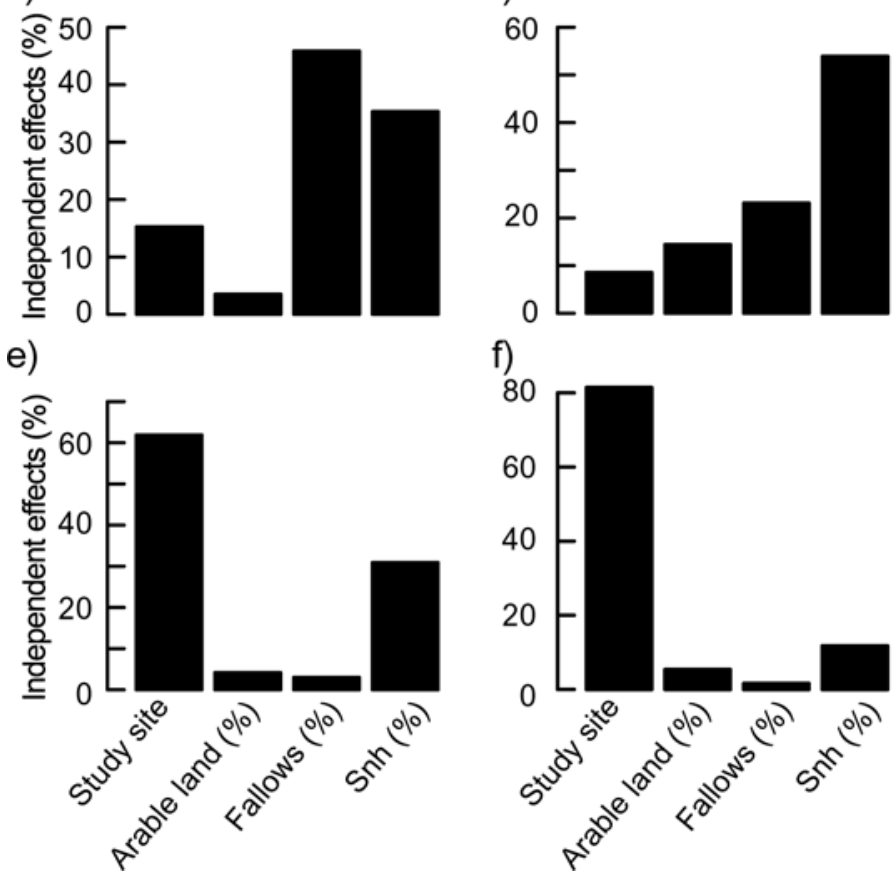

Bumblebees

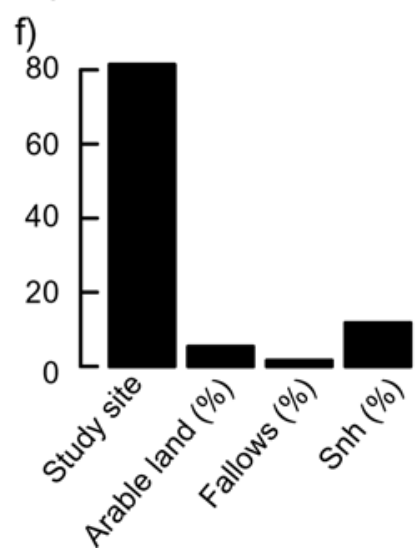

Above groundnesting bees

Figure 3.2 Results of hierarchical partitioning analyses for the independent effects of habitat type and landscape attributes, including amount of arable land (\%),amount of fallows (\%) and amount of seminatural habitats (Snh) (\%), on the abundance and species richness of the three bee groups: (a \& b) solitary ground-nesting bees, (c \& d) bumblebees and (e \& f) above ground-nesting bees.

\section{INFLUENCE OF LANDSCAPE ATTRIBUTES AND HABITAT TYPE ON BEES}

The mixed model analysis for the observed groups confirmed the results of the hierarchical partitioning. Abundance and species richness of ground-nesting bees was positively correlated to the amount of semi-natural habitats in the landscape (abundance: $F_{1,166}=6.38, P<0.05$; species richness: $F_{1,166}=11.58, P<0.001$; see Fig. 3.3a, 3.3b). There was a trend for the amount of fallow to benefit species richness of solitary ground-nesting bees $\left(\mathrm{F}_{1,166}=2.8, \mathrm{P}=0.096\right)$. The amount of arable land in 
the landscape and habitat had no significant effects on the abundance of the solitary ground-nesting bees. Abundance and species richness of bumblebees was increasing with the amount of fallow in the landscapes (abundance: $\mathrm{F}_{1,166}=11.16, \mathrm{P}<0.001$; species richness: $\left.\mathrm{F}_{1,166}=10.80, \mathrm{P}<0.001\right)$ and the amount of semi-natural habitats (abundance: $F_{1,166}=9.49, P<0.01$; species richness: $F_{1,166}=7.85, P<0.01$; see Fig. 3.3c, 3.3d). The amount of arable land had a negative, but only marginally significant effect on the species richness of bumblebees $\left(\mathrm{F}_{1,166}=1.93, \mathrm{P}=0.055\right)$.

a)

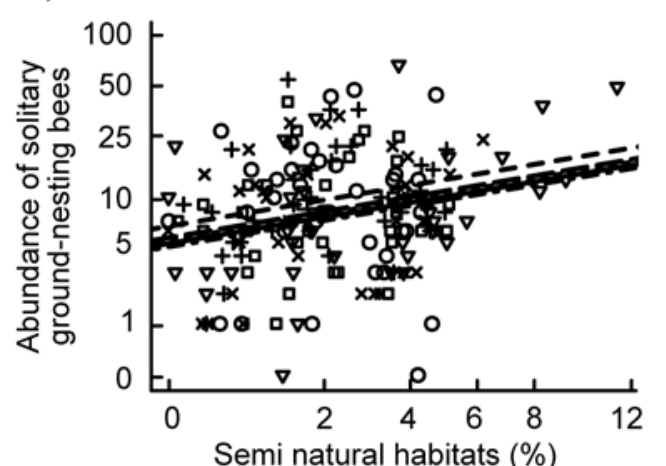

c)

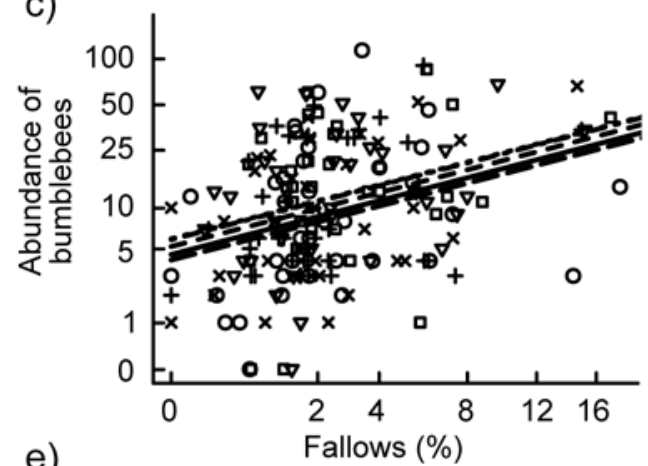

e)

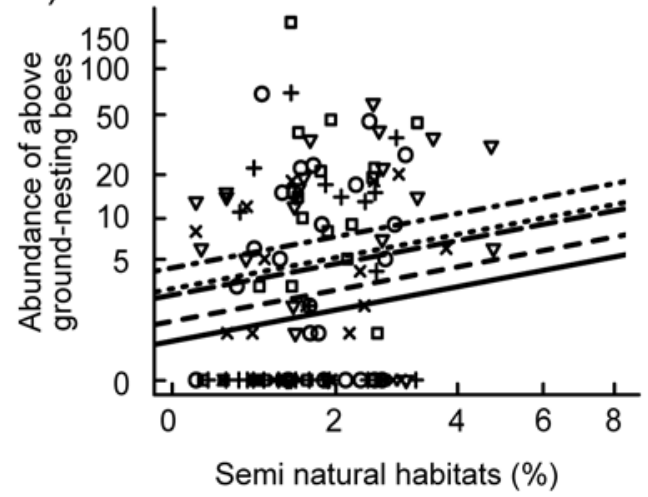

$\rightarrow$ Wheat field

-+ - Field margin

-•ㅂ- Fallow

$\nabla-$ Meadow

b) $\quad-$ Forest edge

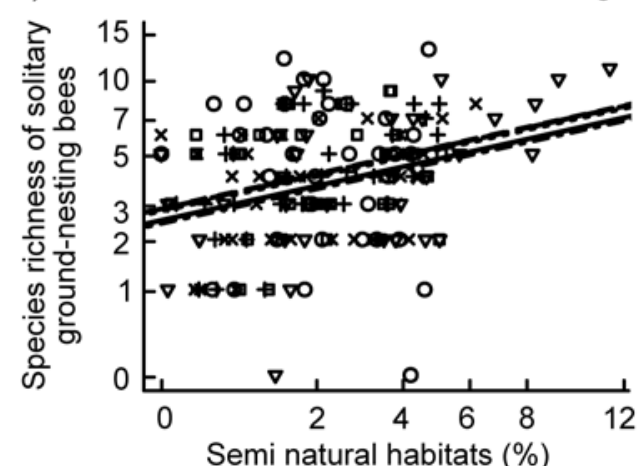

d)

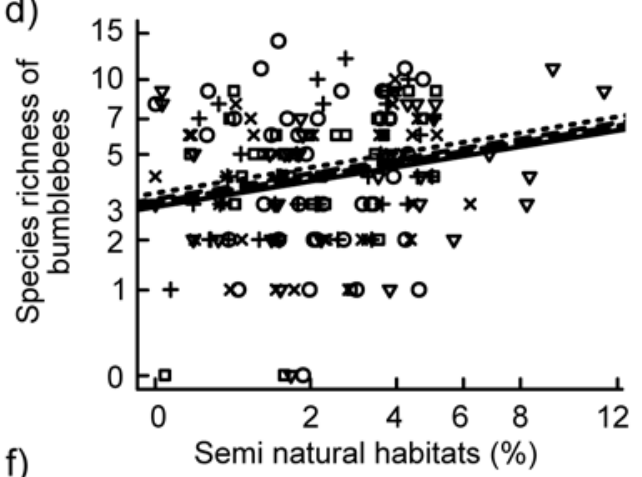

f)

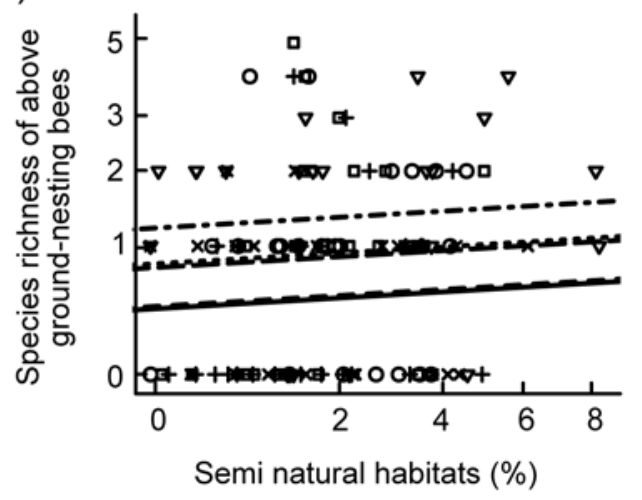

Figure 3.3 Relationships between the abundance and species richness of the three pollinator groups, and the landscape attributes with major independent effects, according to the results of hierarchical partitioning. Solitary ground-nesting bees (a \& b), bumblebees (c \& d) and above ground-nesting bees (e \& f). 
Abundance of above ground-nesting bees was influenced by study site and was highest on the meadow compared to the wheat field $\left(\mathrm{F}_{1,103}=2.80, \mathrm{P}<0.05\right.$; Fig. 3.3e). Species richness of above ground-nesting bees was highest on the meadow, compared to wheat field and field margin $\left(F_{1,103}=3.74, P<0.01\right.$; Fig. 3.3f $)$. All other variables had no significant effect on abundance or species richness of above groundnesting bees. We found no interactions between habitats and environmental variables in any of the models. 


\section{DISCUSSION}

We found a significant decline of fallows from 2006 to 2008. Farmers started to convert fallows into arable fields in 2007, stimulated by the great increase of wheat prices, exceeding the subsidies paid for fallows. As expected, the abundance of bumblebees also declined as fallows vanished from landscapes, which is in line with Lye et al. (2009), who showed that fallows play an important role in offering suitable nesting and foraging resources to bumblebee queens. Bumblebee queens prefer nesting sites hosting withered grass patches (Svensson, Lagerlöf \& Svensson 2000), which is a typical feature of fallows. Goulson et al. (2006) assumed that most bumblebee species are generalists with respect to habitat, but prefer sites that are not influenced by agricultural intensification. Farmers tended to convert the more unprofitable areas in fallows, which are nutrient poor and therefore obtain lower yield. This makes them an especially valuable habitat for bees, not only in terms of bare vegetation providing nesting sites but also hosting flowering resources (Osborne et al. 2008) that do not persist in the nutrient rich and highly disturbed intensively managed production areas (Culman et al. 2010; Kovács-Hostyánszki et al. 2011). Since fallows are only mown once a year in summer with scythed plants left on site, they offer rarely disturbed nesting sites. Previous studies have shown that arthropods may benefit even from rotational fallows, offering them a landscape-scale refuge (Corbet 1995; Schmidt et al. 2008; Sotherton 1998).

The species richness of bumblebees as well as abundance and species richness of solitary ground-nesting bees was positively related to the amount of semi-natural habitats in the landscape, which is in line with the findings of Steffan-Dewenter et al. (2002) and Kohler et al. (2008), underlining the importance of conserving semi-natural habitats as sources of bee diversity in agricultural landscapes. Our results show that across all years abundance and species richness of ground-nesting bees appear to be strongly influenced by landscape attributes and less by habitat type. Possible local habitat effects for ground-nesting bees may have been masked by the selection of a strong landscape gradient as percentage of arable land.

In contrast to ground-nesting bees, abundance and species richness of above groundnesting bees were mainly influenced by the habitat type. Habitats with a higher species 
diversity of flowering plants (see Appendix, A3.1), such as meadow, fallow and forest edge hosted more bee species than wheat field and field margin. This is in support of previous findings that flowering plant diversity is positively correlated to bee species richness (Steffan-Dewenter \& Tscharntke 2001). In accordance with the findings of Tscharntke, Gathmann \& Steffan-Dewenter (1998) and Holzschuh, Steffan-Dewenter \& Tscharntke (2010), the abundance of above ground-nesting bees is determined by the availability of suitable nesting sites, such as hedges and deadwood in the landscape. Intensively used habitat types are lacking nesting opportunities and food resources and are highly disturbed, which makes them unsuitable for bees. Above ground-nesting bees species were affected by habitat type, with an additional positive impact of the amount of semi-natural habitats in the landscapes, especially for abundance.

We showed here that meadows cannot replace fallows as source habitat of bees. While they may function as foraging habitats, the dense grass cover (inhibiting nesting) and high mowing frequencies (compared to once on fallows) limit their value. A long-term study from Switzerland by Aviron et al. (2009) showed that the cross-compliance scheme, implemented 1993 in Switzerland and introduced 2005 in the EU, can only increase farmland biodiversity when a minimum of $7 \%$ of the arable land is fallow. Other studies emphasized the need and effectiveness of biodiversity conservation measures in simple landscapes with a high proportion of arable land (Tscharntke et al. 2005; Concépcion, Díaz \& Baquero 2008; Batáry et al. 2010). However, the total amount of fallow for Germany was substantially less than seven percent (Fig. 3.1) and due to the ongoing losses of semi-natural habitats in the agricultural landscape, effects of the additional discontinuation of fallows after 2006 appeared to have particularly severe effects on pollinators. 


\section{CONCLUSIONS}

In this three-year study we showed that the amount of fallow is declining alarmingly fast in German landscapes, leading to a further reduction of populations of groundnesting bees. Conservation of semi-natural habitats as sources for bee diversity requires special attention, especially in structurally simple landscapes with a high proportion of arable land. The current EU scheme of cross-compliance does not mitigate the negative impact of fallow loss on species richness, thus biodiversity conservation measures enhancing food and nesting resources for wild bees in the landscape are needed to ensure pollination services in agricultural landscapes. 


\section{ACKNOWLEDGEMENTS}

We thank Susanne Schiele for support during field work and for dissecting the trap nests and needling the emerging individuals, the farmers for the usage of their fields, fallows and meadows as experimental sites. We are grateful to the farmers, who let us use their fields as experimental sites during three years. We thank Ines Vollhardt, Stefan Hellmich and Jeroen Everaars for support during the field work, Brigitte Lünemann, Bianca Tappe and Stefan Hellmich for sorting the individuals caught in the pan traps and Stefan Hellmich \& Jochen Fründ for help with species identification in 2008. Species were identified by Frank Burger (2006 \& 2007) and Zsolt Józan (2008). This research was funded by the Helmholtz Association (VH-NG-247). 


\section{REFERENCES}

Aviron, S., Nitsch, H., Jeanneret, P., Buholzer, S., Luka, H., Pfiffner, L., Pozzi, S., Schüpbach, B., Walter, T. \& Herzog, F. (2009) Ecological cross compliance promotes farmland biodiversity in Switzerland. Frontiers in Ecology and the Environment, 7, 247-252.

Banaszak, J. (1992) Strategy for conservation of wild bees in agricultural landscape. Agriculture, Ecosystems \& Environment, 40, 179-192.

Batáry, P., Báldi, A., Kleijn, D. \& Tscharntke, T. (2010) Landscape-moderated biodiversity effects of agri-environmental management: a meta-analysis. Proceedings of the Royal Society B - Biological Sciences, published online, doi: 10.1098/rspb.2010.1923.

Batra, S. (1984) Solitary Bees. Scientific American, 250, 120-127.

Benton, T., Vickery, J. \& Wilson, J. (2003) Farmland biodiversity: is habitat heterogeneity the key? Trends in Ecology \& Evolution, 18, 182-188.

Carvell, C., Meek, W., Pywell, R., Goulson, D. \& Nowakowski, M. (2007) Comparing the efficacy of agri-environment schemes to enhance bumble bee abundance and diversity on arable field margins. Journal of Applied Ecology, 44, 29-40.

Chevan, A. \& Sutherland, M. (1991) Hierarchical partitioning. American Statistician, 45, 90-96.

Concepción, E.D., Díaz, M. \& Baquero, R.A. (2007) Effects of landscape complexity on the ecological effectiveness of agri-environment schemes. Landscape Ecology, 23, 135-148.

Corbet, S. (1987) More Bees Make Better Crops. New Scientist, 115, 40-43

Corbet, S.A. (1995) Insects, plants, and succession: Advantages of long-term set-aside. Agriculture, Ecosystems \& Environment. 53, 201-217.

Crawley, M.J. (2007) The R Book. John Wiley \& Sons Ltd, Chichester, UK. 
Culman, S., Young-Mathews, A., Hollander, A., Ferris, H., Sanchez-Moreno, S., O'Geen, A. \& Jackson, L. (2010) Biodiversity is associated with indicators of soil ecosystem functions over a landscape gradient of agricultural intensification. Landscape Ecology, 25, 1333-1348.

Daily, G. C., Alexander, S., Ehrlich, P. R., Goulder, L., Lubchenko, J., Matson, P. A., Mooney, H. A., Postel, S., Schneider, S. H., Tilman, D. \& Woodwell, G. M. (1997) Ecosystem services: Benefits supplied to human societies by natural ecosystems. Issues in Ecology, 2, 2-16.

ENCA (2008) Safeguarding environmental benefits of set-aside - The European Commission's proposal on the CAP health check. Sustainable Landuse and Agriculture Interest Group, Brussels.

EU-Information about cross compliance. Available at: http://ec.europa.eu/agriculture/ envir/cross-compliance/index_en.htm 05/01/2011-(accessed 05 Jan 2010).

FAO Newsroom (2006). Cereal prices surge to highest levels in decade. Strong implications for meat and other agricultural commodities. Available at: http://www.fao.org.newsroom/en/news/2006/1000459/index.html (accessed 04 May 2011)

FAO Newsroom (2007). Despite record 2007 production cereal prices remain high. Vulnerable populations in developing countries hurt most. Avaiable at: http://www.fao.org.newsroom/en/news/2007/1000723/index.html (accessed 04 May 2011)

Firbank, L., Smart, S., Crabb, J., Critchley, C., Fowbert, J., Fuller, R., Gladders, P., Green, D., Henderson, I. \& Hill, M. (2003) Agronomic and ecological costs and benefits of set-aside in England. Agriculture, Ecosystems \& Environment, 95, 73-85.

Gallai, N., Salles, J., Settele, J. \& Vaissiere, B. (2009) Economic valuation of the vulnerability of world agriculture confronted with pollinator decline. Ecological Economics, 68, 810-821.

Gathmann, A. \& Tscharntke, T. (2002) Foraging ranges of solitary bees. Journal of 
Animal Ecology, 71, 757-764.

Gillings, S., Henderson, I., Morris, A. \& Vickery, J. (2010) Assessing the implications of the loss of set-aside for farmland birds. IBIS, 152, 713-723.

Godfray, H.C.J., Crute, I.R., Haddad, L., Lawrence, D., Muir, J.F., Nisbett, N., Pretty, J., Robinson, S., Toulmin, C. \& Whiteley, R. (2010) The future of the global food system Introduction. Philosophical Transactions of the Royal Society BBiological Sciences, 365, 2769-2777.

Goulson, D., Hanley, M. E., Darvill, B., Ellis, J. S. (2006) Biotope associations and the decline of bumblebees (Bombus spp.). Journal of Insect Conservation, 10, 95-103.

Greenleaf, S., Williams, N., Winfree, R. \& Kremen, C. (2007) Bee foraging ranges and their relationship to body size. Oecologia, 153, 589-596.

Heikkinen, R.K., Luoto, M., Virkkala, R. \& Rainio, K. (2004) Effects of habitat cover, landscape structure and spatial variables on the abundance of birds in an agricultural-forest mosaic. Journal of Applied Ecology, 41, 824-835.

Heikkinen, R.K., Luoto, M., Kuussaari, M. \& Pöyry, J. (2005) New insights into butterfly-environment relationships using partitioning methods. Proceedings of the Royal Society B - Biological Sciences, 272, 2203-2210.

Holzschuh, A., Steffan-Dewenter, I., Kleijn, D. \& Tscharntke, T. (2007) Diversity of flower-visiting bees in cereal fields: effects of farming system, landscape composition and regional context. Journal of Applied Ecology, 44, 41-49.

Holzschuh, A., Steffan-Dewenter, I. \& Tscharntke, T. (2010) How do landscape composition and configuration, organic farming and fallow strips affect the diversity of bees, wasps and their parasitoids?. Journal of Animal Ecology, 79, 491-500.

Ingram, M., Nabhan, G. C. \& Buchmann, S. L., (1996) Impending pollination crisis threatens biodiversity and agriculture. Tropinet, 7,1 . 
Klein, A.M., Steffan-Dewenter, I. \& Tscharntke, T. (2006) Rain forest promotes trophic interactions and diversity of trap-nesting hymenoptera in adjacent agroforestry. Journal of Animal Ecology, 75, 315-323.

Klein, A.M., Vaissière, B.E., Cane, J.H., Steffan-Dewenter, I., Cunningham, S.A., Kremen, C. \& Tscharntke, T. (2007) Importance of pollinators in changing landscapes for world crops. Proceedings of the Royal Society B-Biological Sciences, 274, 303-313.

Kohler, F., Verhulst, J., van Klink, R. \& Kleijn, D. (2008) At what spatial scale do high-quality habitats enhance the diversity of forbs and pollinators in intensively farmed landscapes? Journal of Applied Ecology, 45, 753-762.

Kovács-Hostyánski, A., Batáry, P., Báldi, A., \& Harnos A. (2011). Interaction of local and landscape features in the conservation of Hungarian arable weed diversity. Applied Vegetation Science, 14, 40-48.

Kremen, C., Williams, N. \& Thorp, R. (2002) Crop pollination from wild bees at risk from agricultural intensification. Proceedings of the National Academy of Scienes of the United States of America, 99, 16812-16816.

Landis, D., Gardiner, M., van der Werf, W. \& Swinton, S. (2008) Increasing corn for biofuel production reduces biocontrol services in agricultural landscapes. Proceedings of the National Academy of Sciences of the United States of America, 105, 20552-20557.

Losey, J. \& Vaughan, M. (2006) The economic value of ecological services provided by insects. BioScience, 56, 311-323.

Lye, G., Park, K., Osborne, J., Holland, J. \& Goulson, D. (2009) Assessing the value of Rural Stewardship schemes for providing foraging resources and nesting habitat for bumblebee queens (Hymenoptera: Apidae). Biological Conservation, 142, 2023-2032.

MacDonald, D., Tattersall, F., Service, K., Firbank, L. \& Feber, R. (2007) Mammals, agri-environment schemes and set-aside - what are the putative benefits? Mammal Review, 37, 259-277. 
Mc Nally, R. (1996) Hierarchical Partitioning as an interpretative tool in multivariate inference. Australian Journal of Ecology, 21, 224-228.

Mc Nally, R. (2000) Regression and model-building in conservation biology, biogeography and ecology: The distinction between - and reconciliation of "predictive” and explanatory models. Biodiversity \& Conservation, 9, 655-671.

Nabhan, G.P. \& Buchmann, S.L. (1997) Services provided by pollinators. Nature's Services - Societal Dependence On Natural Ecosystems (eds G.C. Daily), pp. 133-150. Island Press, Washington DC, USA.

Öckinger, E. \& Smith, H. (2007) Semi-natural grasslands as population sources for pollinating insects in agricultural landscapes. Journal of Applied Ecology, 44, $50-59$.

Olea, P.P., Mateo-Tomás, P. \& de Frutos, Á. (2010) Estimating and Modelling Bias of the Hierarchical Partitioning Public-Domain Software: Implications in Environmental Management and Conservation. PLoS One, 5, e11698.

Osborne, J., Martin, A., Shortall, C., Todd, A., Goulson, D., Knight, M., Hale, R. \& Sanderson, R. (2008) Quantifying and comparing bumblebee nest densities in gardens and countryside habitats. Journal of Applied Ecology, 45, 784-792.

Pinheiro, J., Bates, D., DebRoy, S., Sarkar, D \& the R Development Core Team (2009) nlme: Linear and Nonlinear Mixed Effects Models. R package version 3.1-96.

R Development Core Team (2010) A Language and Environment for Statistical Computing, $\mathrm{R}$ Foundation for Statistical Computing, Vienna, Austria. Available at: http://www.R-project.org (accessed 21 Aug 2010).

Rosegrant, M. \& Cline, S. (2003) Global food security: Challenges and policies. Science, 302, 1917-1919.

Schmidt, M., Rocker, S., Hanafi, J. \& Gigon, A. (2008) Rotational fallows as overwintering habitat for grassland arthropods: the case of spiders in fen meadows. Biodiversity and Conservation, 17, 3003-3012. 
Sotherton, N.W. (1998) Land use changes and the decline of farmland wildlife: An appraisal of the set-aside approach. Biological Conservation, 83, 259-268.

Statistisches Bundesamt Deutschland - Table of land use in Germany for the years 2007 to 2010. Availabe at: http://www.destatis.de/jetspeed/portal/cms/Sites/destatis/Internet/DE/Content/Statistiken/LandForstwirtschaft/Bodennutzung/Ta bellen/Content75/AckerlandHauptfruchtgruppenFruchtarten,templateId=render Print.psml (accessed 02 Apr 2011).

Steffan-Dewenter, I. \& Tscharntke, T. (1997) Early succession of butterfly and plant communities on set-aside fields. Oecologia, 109, 294-302.

Steffan-Dewenter, I. \& Tscharntke, T. (2001) Succession of bee communities on fallows. Ecography, 24, 83-93.

Steffan-Dewenter, I. (2002) Landscape context affects trap-nesting bees, wasps, and their natural enemies. Ecological Entomology, 27, 631-637.

Steffan-Dewenter, I., Münzenberg, U., Bürger, C., Thies, C. \& Tscharntke, T. (2002) Scale-dependent effects of landscape context on three pollinator guilds. Ecology, 83, 1421-1432.

Steffan-Dewenter, I. (2003) Importance of habitat area and landscape context for species richness of bees and wasps in fragmented orchard meadows. Conservation Biology, 17, 1036-1044.

Steffan-Dewenter, I., Potts, S. \& Packer, L. (2005) Pollinator diversity and crop pollination services are at risk. Trends in Ecology \& Evolution, 20, 651-652.

Stoate, C., Baldi, A., Beja, P., Boatman, N., Herzon, I., van Doorn, A., de Snoo, G., Rakosy, L. \& Ramwell, C. (2009) Ecological impacts of early 21st century agricultural change in Europe - A review. Journal of Environmental Management, 91, 22-46.

Svensson, B., Lagerlöf, J. \& Svensson, B.G. (2000) Habitat preferences of nestseeking bumblebees (Hymenoptera: Apidae) in an agricultural landscape. Agriculture, Ecosystems \& Environment, 77, 247-255. 
Tattersall, F., Avundo, A., Manley, W., Hart, B. \& Macdonald, D. (2000) Managing set-aside for field voles (Microtus agrestis). Biological Conservation, 96, $123-128$.

Teodoro, A., Klein, A.M. \& Tscharntke, T. (2008) Environmentally mediated coffee pest densities in relation to agroforestry management, using hierarchical partitioning analyses. Agriculture, Ecosystems \& Environment, 125, 120-126.

Thies, C. \& Tscharntke, T. (1999) Landscape structure and biological control in agroecosystems. Science, 285, 893-895.

Tilman, D., Fargione, J., Wolff, B., D'Antonio, C., Dobson, A., Howarth, R., Schindler, D., Schlesinger, W., Simberloff, D. \& Swackhamer, D. (2001) Forecasting agriculturally driven global environmental change. Science, 292, 281-284.

Tscharntke, T., Greiler, H.J., Steffan-Dewenter, I., Kruess, A., Gathmann, A., Zabel, J., Wesserling, J., Dubbert, M., Kuhnhenne, J. \& Vu, M.H. (1996) Die Flächenstillegung in der Landwirtschaft - eine Chance für Flora und Fauna der Agrarlandschaft? (Set-aside in agriculture - a chance for plant and animal communities of the agricultural landscape?). NNA-Berichte (Alfred-ToepferAkademie, Schneverdingen), 2/96, 59-72.

Tscharntke, T., Gathmann, A. \& Steffan-Dewenter, I. (1998) Bioindication using trapnesting bees and wasps and their natural enemies: community structure and interactions. Journal of Applied Ecology, 35, 708-719.

Tscharntke, T. \& Brandl, R. (2004) Plant-insect interactions in fragmented landscapes. Annual review of Entomology, 49, 405-430.

Tscharntke, T., Klein, A.M., Kruess, A., Steffan-Dewenter, I. \& Thies, C. (2005) Landscape perspectives on agricultural intensification and biodiversity ecosystem service management. Ecology Letters, 8, 857-874.

Van Buskirk, J. \& Willi, Y. (2004) Enhancement of farmland biodiversity within setaside land. Conservation Biology, 18, 987-994. 
Westphal, C., Bommarco, R., Carre, G., Lamborn, E., Morison, N., Petanidou, T., Potts, S., Roberts, S., Szentgyorgyi, H., Tscheulin, T., Vaissiere, B., Woyciechowski, M., Biesmeijer, J., Kunin, W., Settele, J. \& Steffan-Dewenter, I. (2008) Measuring bee diversity in different European habitats and biogeographical regions. Ecological Monographs, 78, 653-671.

Westrich, P. (1989) Die Wildbienen Baden-Württembergs: Spezieller Teil. Verlag Eugen Ulmer, Stuttgart, Germany.

Westrich, P. (1996) Habitat requirements of central European bees and the problems of partial habitats. The Conservation of Bees (eds A. Matheson, S.L. Buchmann, C. O’Toole, P. Westrich \& I.H. Williams) pp. 1-16. Academic Press, London, UK.

Walsh, C. \& Mac Nally, R. (2008) hier.part: Hierarchical Partitioning. R package version $1.0-3$.

Wetterstation Göttingen online, Available at: http://www.wetterstation-göttingen.de (accessed 05 Apr 2011)

Whittingham, M. (2007) Will agri-environment schemes deliver substantial biodiversity gain, and if not why not? Journal of Applied Ecology, 44, 1-5.

Winfree, R., Williams, N., Dushoff, J. \& Kremen, C. (2007) Native bees provide insurance against ongoing honey bee losses. Ecology Letters, 10, 1105-1113. 


\section{APPENDIX}

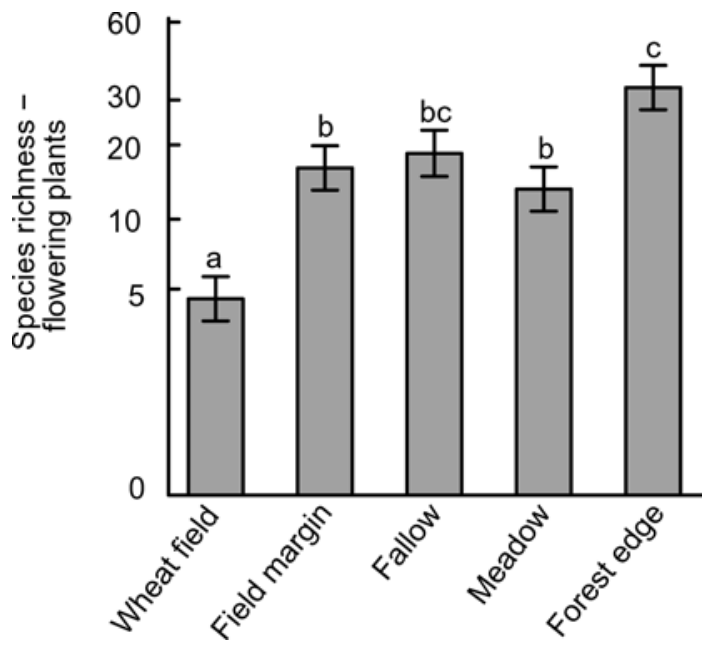

A3.1 Mean species richness of flowering plants in the five different habitat types. Given are mean value \pm SEM.

A3.2 Correlation matrix for the measured landscape attributes, tested with Pearson's product-moment correlation.

\begin{tabular}{lccccc} 
& \multicolumn{1}{c}{ Amount of arable land (\%) } & \multicolumn{2}{c}{ Amount of fallow (\%) } \\
\hline & $r_{\mathrm{p}}$ & $\mathrm{P}$ & $r_{\mathrm{p}}$ & $\mathrm{P}$ \\
Amount of fallows (\%) & -0.405 & $<0.001$ & & \\
Amount of semi-natural habitats (\%) & -0.403 & $<0.001$ & 0.481 & $<0.001$ \\
\hline
\end{tabular}

A3.3 Survey of the percentage of independent effects (in \%) resulting from hierarchical partitioning analyses for the influence of habitat types and landscape attributes on abundance and species richness of the bee groups, solitary ground- nesting bees, bumblebees, above ground-nesting bees.

\begin{tabular}{lccc} 
& $\begin{array}{c}\text { Solitary ground- } \\
\text { nesting bees }\end{array}$ & Bumblebees & $\begin{array}{c}\text { Above ground- } \\
\text { nesting bees }\end{array}$ \\
\hline Abundance & Independent effects & Independent effects & Independent effects \\
Habitat type & 19.85 & 15.27 & 61.89 \\
Amount of arable land (\%) & 2.91 & 3.53 & 4.19 \\
Amount of fallow (\%) & 4.81 & 45.46 & 3.02 \\
Amount semi-natural habitats (\%) & 72.43 & 46.54 & 30.90 \\
Species richness & & & \\
Habitat type & 10.69 & 8.56 & 81.41 \\
Amount of arable land (\%) & 2.85 & 14.42 & 5.33 \\
Amount of fallow (\%) & 4.93 & 23.12 & 1.54 \\
Amount of semi-natural habitats (\%) & 81.53 & 53.90 & 11.72 \\
\hline
\end{tabular}


CHAPTER

4

SPECIES RICHNESS AND HOST-PARASITOID NETWORK STRUCTURE

CHANGING WITH LAND USE TYPE AND

LANDSCAPE COMPLEXITY

Kristin M. Krewenka, Andrea Holzschuh, Teja Tscharntke, Carsten F. Dormann

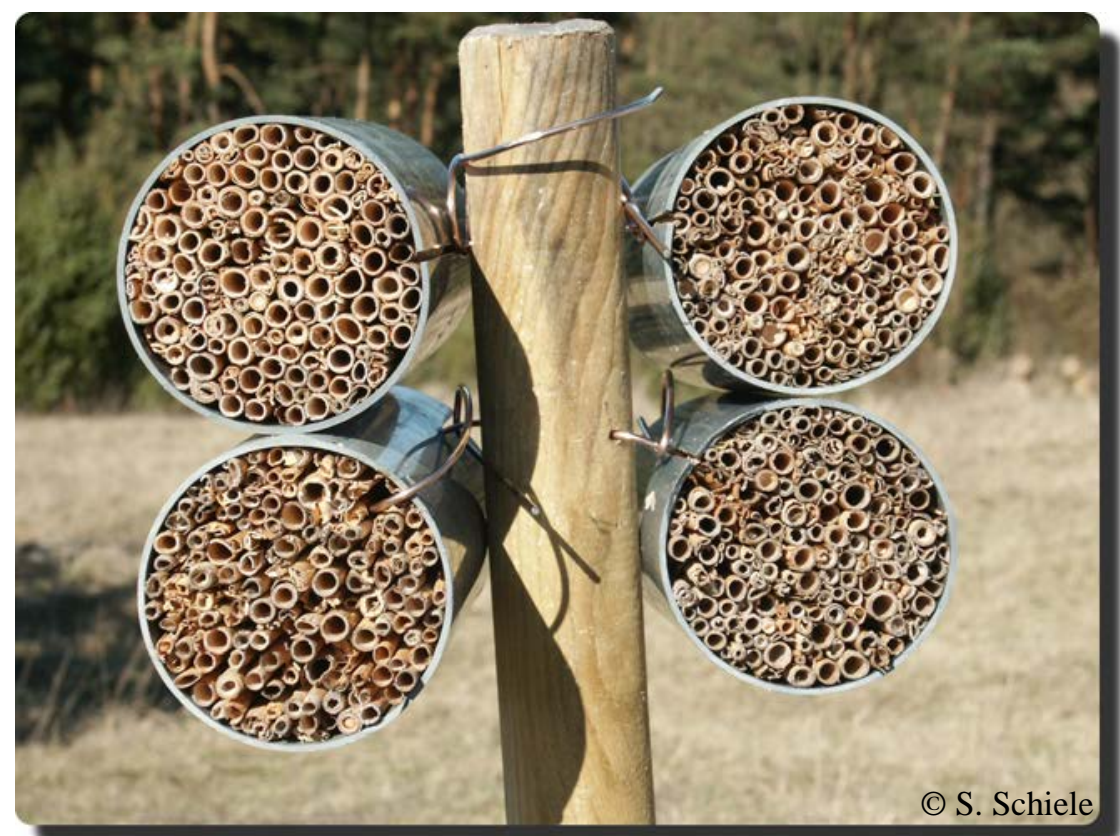

(in prep.) 


\section{ABSTRACT}

The effects of agricultural intensification are well documented, but evidence for the relative role of land use type and landscape structure on trophic interactions and network structure is still limited. In this study we compare quantitative food webs of trap-nesting bees, wasps and their parasitoids in five different habitat types, representative for the Central European agricultural area, over a landscape complexity gradient and a time span of two years.

We found that intensively managed habitat types and low landscape complexity affected the species richness and abundance of host-parasitoid communities negatively in both years. Although species composition varied in the two years of observation, the diversity of interaction links and the number of links per species were highest in high quality habitats, while connectance, as indicator for network complexity, increased with decreasing landscape complexity. We conclude that high-quality habitats are crucial for maintaining balanced interactions between hosts and parasitoids and that decreasing landscape complexity has a destabilizing effect on host-parasitoid communities in agricultural landscapes by reducing their species richness and interaction diversity.

\section{KEYWORDS}

Bees, food webs, habitat type, landscape complexity, parasitoids, wasps 


\section{INTRODUCTION}

In the last decades agricultural intensification and the associated habitat degradation and loss have been identified as major threats to biodiversity in agroecosystems (Tilman et al. 2001; Benton, Vickery \& Wilson 2003). Maintaining biodiversity is key preserving important biologically driven ecosystem services, which are essential for human well-being (Altieri 1999; Daily 1997). Therefore a central conservation issue in intensively used agricultural landscapes is to preserve and protect species diversity and their interactions to ensure ecosystem functioning (Pimm 1991; Thébault \& Loreau 2006). Food webs including different trophic levels are commonly used to identify patterns of these interactions (Müller et al. 1999; Solé \& Montoya 2001; Lewis et al. 2002; Tylianakis, Tscharntke \& Lewis 2007). Food web indices help to compare and evaluate food webs and to detect systematic food web structures (Blüthgen et al. 2008). Most qualitative descriptors of food web structure have found to be highly confounded with sampling effort, therefore quantitative food web indices, which account for the dimension of interactions of different species are more suited to identify patterns of food web structure (Banasek-Richter, Cattin \& Bersier 2004). The advantage of quantitative food webs is that they allow us to assess the strength of links between species and obtain information about structure and functions in this community in addition to species abundance and species richness (Albrecht et al. 2007; Lewis et al. 2002). Biodiversity loss is supposed to lead to reduced stability of food webs (McCann 2000) and may result in skewed interaction webs, destabilising the community (Borrvall, Ebenmann \& Jonsson 2000).

Insect parasitoid-host assemblages are extremely well suited study systems to evaluate changes in community interactions, since their generation cycle is equal and the response of parasitoids is co-instantaneous with host population growth (Holt \& Lawton 1993). The knowledge on influences of habitat type and landscape complexity on host-parasitoid interactions is still limited, especially regarding trap-nesting bees and wasps and their parasitoids, and previous single-habitat studies have yielded equivocal results (Steffan-Dewenter 2002; Tylianakis, Tscharntke \& Klein 2006; Albrecht et al. 2007; Holzschuh, Steffan-Dewenter \& Tscharntke 2010; Veddeler et al. 2010). Our study is the first to assess the implications of landscape structure on hostparasitoid interactions in several different habitat types in temperate regions, taking the 
management intensity of each habitat and influence of the surrounding landscape on species abundance, richness and their interactions into account.

Bees are the most important pollinators in the northern hemisphere and many wild plants rely on insect pollination for seed production (Klein et al. 2007). Crops, in particular vegetable-and fruit cultivars, rely on pollination for producing optimal yield, but the ongoing declines in honeybees (Potts et al. 2010; Watanabe 1994) and wild bee populations (Biesmeijer et al. 2006) imperil this essential ecosystem service (Cane 1997; Kremen, Williams \& Thorp 2002; Ricketts et al. 2008; Winfree et al. 2007).

Predatory wasps contribute to biological control of pest species, hunting larvae of lepidopterans (leaf miners) or aphids for feeding their offspring (Danks 1970; Tylianakis, Tscharntke \& Klein 2006). Recent studies showed that these wasps depend on natural habitats in the landscape, offering them food and nesting resources, and that they are negatively affected by habitat fragmentation or loss (Holzschuh, SteffanDewenter \& Tscharntke 2009; Krewenka et al. 2011, in press.).

Parasitoids can be important for regulating host populations, potentially dampening host population fluctuations and thus stabilizing ecosystem functioning (Henson, Craze \& Memmott 2009). Diversity of parasitoids is usually affected more negatively by the fragmentation or loss of habitats in the landscape than that of their hosts, due to their smaller body size, limited dispersal ability and their often small and variable population sizes (Davies, Margules \& Lawrence 2000; Kruess \& Tscharntke 2000; van Nouhuys 2005).

In this study we focused on the influence of habitat type and landscape complexity on trap-nesting bees and wasps and their parasitoids in five different habitat types along a gradient of landscape complexity. These were i) conventionally managed winter wheat field, ii) grassy field margin strip located at the border of the focal wheat field, iii) intensively managed grassland, iv) fallow and v) forest edge. These study sites comprise a gradient of management intensity, with wheat fields as a highly disturbed, intensively used habitat, and even the quality of field margin strips is likely to be negatively influenced by the application of agrochemicals to the adjacent wheat field and mowing in June. The meadows were conventionally managed, enriched with fertilizer and mown at least twice a year, whereas fallows were extensively used, nutrient poor habitats, mown only once a year and the cut plants left on the site. Forest edges were the least undisturbed habitats, hosting a variety of flowering shrubs and herbs and were assumed to have the highest quality, serving as 
source habitats for trap-nesting bees and wasps. We hypothesize that: (i) Abundance and species richness of hosts and their parasitoids and parasitism rates are higher in natural habitats than in intensively farmed habitats; (ii) abundance and species richness of hosts, parasitoids and parasitism rates increase with increasing landscape complexity; and iii) decreasing landscape complexity results in simpler networks. 


\section{MATERIALS AND METHODS}

\section{STUDY AREA AND SITES}

The study was conducted in 2007 and 2008 in the vicinity of Göttingen, Lower Saxony, Germany. The landscape is dominated by intensive agriculture, with embedded patches of forest and semi-natural habitats in different sizes. Twelve differentially structured landscapes were selected, with the amount of arable land being the measure of complexity. The amount of arable land was negatively correlated with Shannon diversity of habitat types in the landscape (Pearson's product-moment correlation: $\mathrm{r}_{\mathrm{P}}=-0.84, \mathrm{P}<0.0001, \mathrm{n}=60$ ). In each landscape we chose five different habitats, representing different land-use types of the agricultural landscape in Germany (60 sites in total). Since species richness of flowering plants is a good indicator for the richness of bees (Steffan-Dewenter and Tscharntke, 2001), we recorded the vegetation on each site in 15 randomly selected $2 \times 2 \mathrm{~m}$ plots and used this as measure of habitat type quality. Species richness of flowering plants was highest on the forest edge and lowest on the wheat field (lme: $F_{4,43}=14.110, \mathrm{P}<0.001$ ) (see Appendix, A4.2). Due to crop rotation, we had to change the location of the wheat field and the adjacent field margin strip once per landscape throughout the two years. We switched to wheat fields that were situated nearby to minimize changes in the landscape composition. In both years we mapped land-use types in the surrounding landscape of each habitat type in a radius of $1000 \mathrm{~m}$. For calculation of the amount of arable land (annual cereal crop fields) we used the program ESRI ${ }^{\circledR}$ ArcView 2.3. The proportion of arable land ranged from $17.46 \%$ to $89.53 \%$ (mean $51.26 \% \pm 2.73$ SEM).

\section{DATA COLLECTION}

For monitoring the trophic interactions of trap-nesting bees and wasps we used standardized trap-nests. Gathmann, Greiler and Tscharntke (1994) showed, that these traps are an excellent instrument covering the nesting activities of hosts as well as the parasitism events by their natural enemies. The trap nests consisted of plastic tubes with a diameter of $12.5 \mathrm{~cm}$ filled with approximately 200 reed internodes with a diameter of 0.2 to $1 \mathrm{~cm}$ to attract different species of trap-nesting bees and wasps.

Every two of these traps were fixed on a wooden pole at a height of $1.20 \mathrm{~m}$ in

the focal habitat types. Within each habitat we installed two poles trap nests at a distance of $50 \mathrm{~m}$. In total, there were 240 trap nests in 2007 and 236 trap nests in 2008, 
since a fallow in one landscape was abolished. In both years trap nests were exposed from the second week of April to the first week of August, when wheat harvesting took place. During the time of trap exposure, the farmers did not apply any crop protection near the trap nests.

The occupied reed internodes were dissected and parasitism events were recorded. The reed internodes were then kept at a temperature of $4^{\circ}$ Celsius to stimulate larval development. After six weeks they were stored at room temperature and the emerging adult individuals were determined to species level. Individuals that did not develop, were determined to genus level (in case of Eumeninae spp. to subfamily level) on the basis of special features of nest construction.

\section{STATISTICAL ANALYSES}

The statistical analyses were carried out using R (version 2.11.1, R Development Core Team 2010). Following Banasek-Richter, Cattin and Bersier (2004), we used quantitative food webs for analyses. Network analyses and calculation of food web indices were conducted using the package bipartite (Dormann et al. 2009). Food web metrics were estimated if more than one parasitoid was present. When there were less than five results for the food web indices of habitat types, due to low interaction rates, we excluded these. This was the case, regarding field margin and wheat field in 2007. Therefore, we obtained 35 networks for 2007 and 48 networks for 2008. Trap-nesting bees and wasps were combined as hosts to obtain suitable networks sizes. We included individuals determined to species level and additionally the individuals for genus level, for receiving maximal information of species assemblages.

Effects of landscape parameters and habitat types on abundance and species richness of hosts, abundance and species richness of parasitoids, parasitism rates and network indices were analysed using linear mixed-effects models (lmes) employing the nlme package (Pinheiro et al. 2009) and conducted for each year separately. P-values were corrected using the Holm method for multiple comparisons (Aickin \& Gensler 1996). The twelve landscapes were included as random factor to account for the nested study design. Fixed factors were percentage of arable land, habitat type and their interaction. Abundance of hosts was the total number of brood cells. The abundance of parasitoids was the total number of parasitized brood cells. Parasitism rates were calculated using the coefficient of parasitized brood cells and total host brood cells. Expected estimates for the observed networks, were calculated, using 1000 
randomized replicate null models for the observed values of each food web. We used z-scores for comparing expected and observed models, i.e. standardisations of observed values $(O)$ by null model sample mean $\left(\bar{x}_{N}\right)$ and standard deviation $\left(s_{N}\right)$ :

$$
z=\frac{O-\bar{x}_{N}}{s_{N}}
$$

The z-score quantifies, in multiples of null model standard deviations, the difference between observed values (raw score) and expected (null model sample mean).

\section{NETWORK INDICES}

For assessing measures of network interactions, we used the indices estimates, provided by the bipartite package (for detailed calculation information, see Dormann et al. 2009). These were (i) Shannon diversity of interaction links, as measure of diversity of host-parasitoid interactions; ii) Generality, calculated with weighted mean of predator species interactions, as measure of the mean number of prey species per predator; (iii) Weighted Linkage density (sensu Tylianakis; Tscharntke \& Lewis 2007), using the weighted mean of links across species for calculation, as measure of the mean number of links per species; (iv) Mean number of shared hosts, as measure of co-occurrence and even host-preferences; (v) Mean number of shared predators, as measure of shared parasitoid species (vi) Connectance, calculated as proportion of all possible links between occurring species, as measure of the standardized number of species combinations; (vii) Nestedness, as a measure of the probability that specialised species are a subset of generalistic species in the observed network. 


\section{RESULTS}

In 2007 a total of 6896 brood cells were constructed by 47 host species and were parasitized by 11 parasitoid species, the overall parasitism rate was $16.47 \%$. In 2008, the number of constructed brood cells nearly doubled to 12 938, built by 38 host species, which were attacked by 11 parasitoid species and resulted in a overall parasitism rate of $12.22 \%$.

In 2007 the food webs were clearly dominated by wasps of the families Eumeninae and Sphecidae (Trypoxylon spp., being most abundant), while in 2008 the red mason bee (Osmia rufa) was most abundant. Structure of food webs differed strikingly over the five study areas (Fig. 4.1), less species and fewer interactions were observed in the intensively managed monocultural habitat wheat field and the adjacent grass strip and became more complex in the diverse habitats, such as fallow, meadow and forest edge.

EFFECTS OF THE DIFFERENT HABITATS AND LANDSCAPE COMPLEXITY ON ABUNDANCES AND SPECIES RICHNESS

In 2007 we observed a significant effect of different habitats on abundance and species richness (Table 4.1; Fig. 4.2a and 4.2c) of host and parasitoids, with forest edge having the highest abundance and differing significantly from the wheat field and field margin strip whereas in 2008 the amount of arable land explained their abundance and species richness (Table 4.1; Fig. 4.2b and 4.2d). Species richness of hosts and parasitoids in 2008 was influenced by the habitat, as well. Trap-nests at the forest edge were occupied by significantly more host and parasitoid species, compared to the wheat field (Table 4.1; Fig. 4.2d and 4.2e). In 2007, parasitism rates were clearly affected by habitat and were highest at the forest edge (lme: 2007, $\mathrm{F}_{4,43}=6.41$; $\mathrm{P}<0.001$; Fig. 2 c). In 2008 parasitism rates decreased with increasing amount of arable land (lme: $F_{1,46}$ = 6.78; $\mathrm{P}=0.012$; Fig. $2 \mathrm{f}$ ).

EFFECTS OF THE DIFFERENT HABITAT TYPES AND LANDSCAPE COMPLEXITY ON FOODWEB METRICS

In both years the Shannon diversity of interactions was highest at the forest edge and lowest on the fallow and in the wheat field (Table 4.2; Fig. 4.3a and 4.3f). 
Wheat field 2007

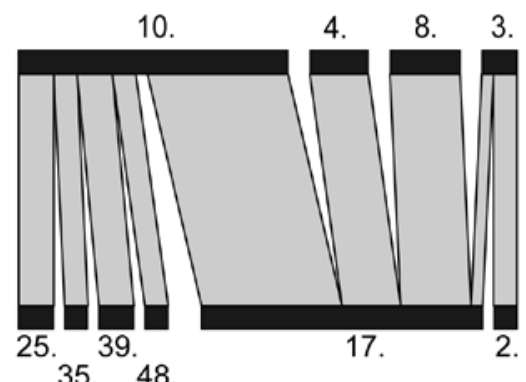

Field margin 2007

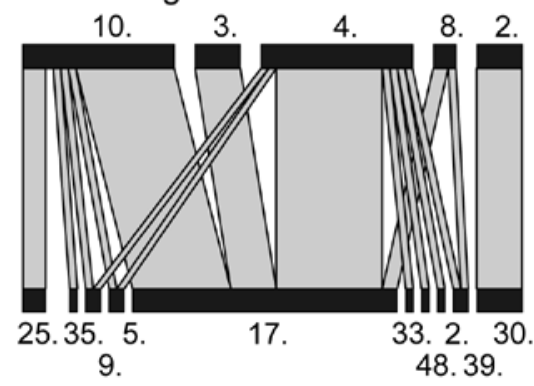

Fallow 2007

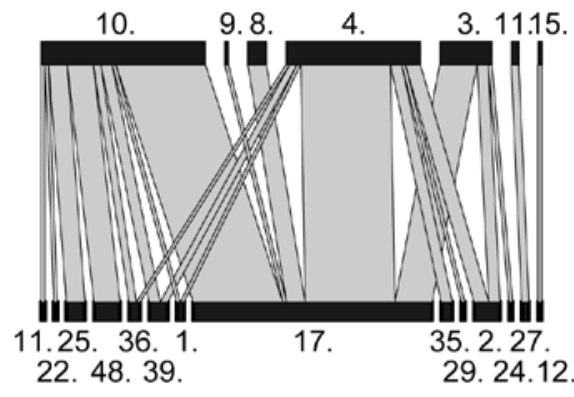

Meadow 2007

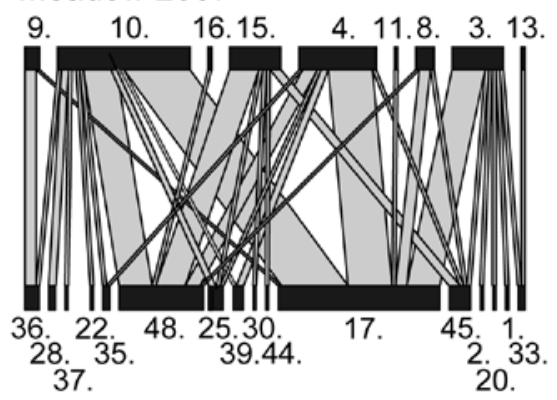

Forest edge 2007

$$
7 .
$$

17. 16.

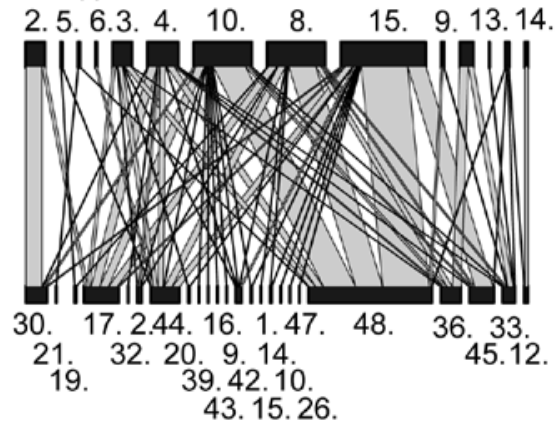

Wheat field 2008

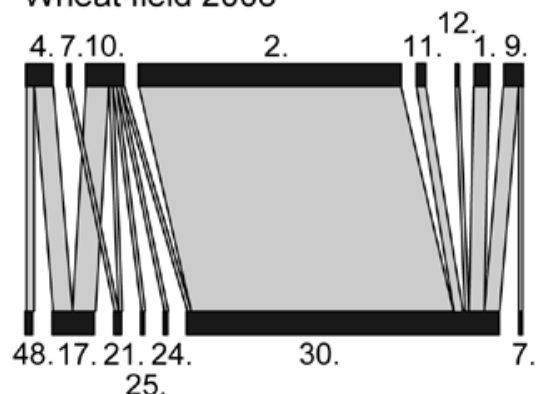

Field margin 2008

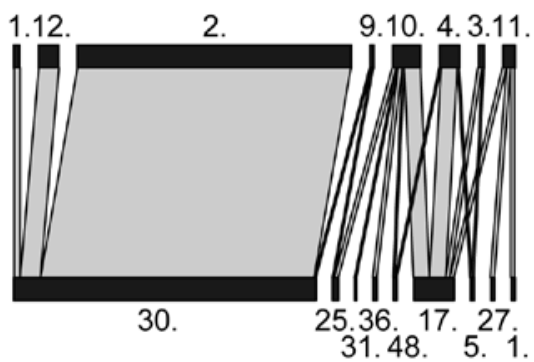

Fallow 2008

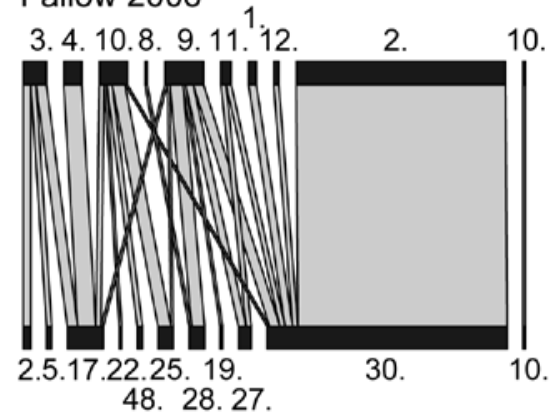

Meadow 2008

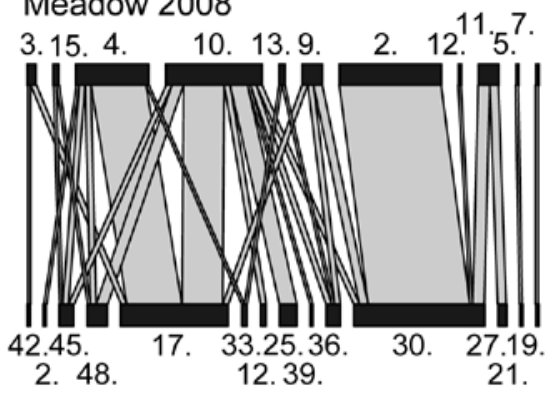

Forest edge 2008

11.13. 3.

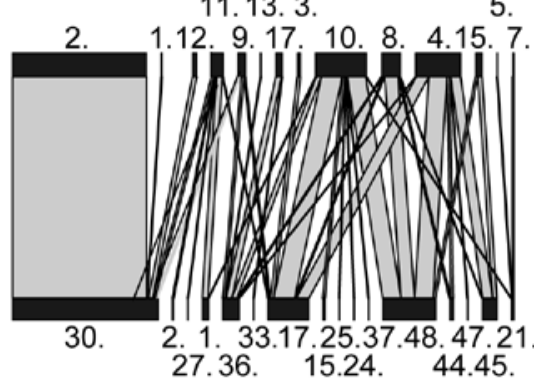

Figure 4.1 Quantitative Food webs for the five different habitats in the years 2007 (left side) and 2008 (right side), over the 12 landscapes, upper bars present the parasitoid species, lower bars the host species that were present. (Species list, see Appendix, A4.1) 
Table 4.1 Effect of five different habitats and landscape complexity (percentage of arable land) on abundance of hosts and parasitoids. Results are derived from linear mixed-effects models. P-values of post-hoc comparisons of habitat differences were adjusted according to the Holm method.

\begin{tabular}{|c|c|c|c|c|c|c|c|c|}
\hline \multirow[t]{2}{*}{ Abundance } & \multicolumn{2}{|c|}{$\begin{array}{l}2007 \\
\text { Hosts }\end{array}$} & \multicolumn{2}{|c|}{$\begin{array}{c}2007 \\
\text { Parasitoids }\end{array}$} & \multicolumn{2}{|c|}{$\begin{array}{l}2008 \\
\text { Hosts }\end{array}$} & \multicolumn{2}{|c|}{$\begin{array}{c}2008 \\
\text { Parasitoids }\end{array}$} \\
\hline & $\mathrm{F}$ & $\mathrm{P}$ & $\mathrm{F}$ & $\mathrm{P}$ & $\mathrm{F}_{1,46}$ & $\mathrm{P}$ & $\mathrm{F}_{1,42}$ & $\mathrm{P}$ \\
\hline Amount of arable land & $-*$ & - & $-*$ & - & 6.78 & 0.012 & 11.27 & 0.002 \\
\hline Habitat type & $\mathrm{F}_{4,44}$ & $\mathrm{P}$ & $\mathrm{F}_{4,44}$ & $\mathrm{P}$ & $\mathrm{F}_{1,42}$ & $\mathrm{P}$ & $\mathrm{F}_{4,42}$ & $\mathrm{P}$ \\
\hline Full model & 5.95 & $<0.001$ & 10.37 & $<0.001$ & - & - & 3.81 & 0.010 \\
\hline Wheat field - grass strip & & 1.000 & & 0.530 & & & & 0.262 \\
\hline Wheat field - fallow & & 0.530 & & 0.006 & & & & 0.672 \\
\hline Wheat field - meadow & & 0.530 & & 0.009 & & & & 0.552 \\
\hline Wheat field - forest edge & & 0.003 & & $<0.001$ & & & & 0.004 \\
\hline Grass strip - fallow & & 0.460 & & 0.060 & & & & 1.000 \\
\hline Grass strip - meadow & & 0.460 & & 0.071 & & & & 1.000 \\
\hline Grass strip - forest edge & & $<0.001$ & & $<0.001$ & & & & 0.490 \\
\hline Fallow- meadow & & 1.000 & & 0.837 & & & & 1.000 \\
\hline Fallow- forest edge & & 0.082 & & 0.060 & & & & 0.166 \\
\hline Forest edge - meadow & & 0.087 & & 0.071 & & & & 0.131 \\
\hline \multirow[t]{2}{*}{ Species richness } & \multicolumn{2}{|c|}{$\begin{array}{l}2007 \\
\text { Hosts }\end{array}$} & \multicolumn{2}{|c|}{$\begin{array}{c}2007 \\
\text { Parasitoids }\end{array}$} & \multicolumn{2}{|c|}{$\begin{array}{c}2008 \\
\text { Hosts }\end{array}$} & \multicolumn{2}{|c|}{$\begin{array}{c}2008 \\
\text { Parasitoids }\end{array}$} \\
\hline & $\mathrm{F}_{1,43}$ & $\mathrm{P}$ & $\mathrm{F}$ & $\mathrm{P}$ & $\mathrm{F}_{1,42}$ & $\mathrm{P}$ & $\mathrm{F}_{1,42}$ & $\mathrm{P}$ \\
\hline Amount of arable land & 15.10 & $<0.001$ & $-*$ & - & 5.10 & 0.029 & 10.85 & 0.002 \\
\hline Habitat type & $\mathrm{F}_{4,43}$ & $\mathrm{P}$ & $\mathrm{F}_{4,44}$ & $\mathrm{P}$ & $\mathrm{F}_{4,42}$ & $\mathrm{P}$ & $\mathrm{F}_{4,42}$ & $\mathrm{P}$ \\
\hline Full model & 13.92 & $<0.001$ & 16.52 & $<0.001$ & 5.65 & 0.001 & 5.16 & 0.002 \\
\hline Wheat field - grass strip & & 0.959 & & 0.338 & & 0.498 & & 1.000 \\
\hline Wheat field - fallow & & 0.019 & & 0.015 & & 0.361 & & 1.000 \\
\hline Wheat field - meadow & & 0.019 & & $<\mathbf{0 . 0 0 1}$ & & 0.024 & & 0.405 \\
\hline Wheat field - forest edge & & $<0.001$ & & $<0.001$ & & 0.001 & & 0.002 \\
\hline Grass strip - fallow & & 0.041 & & 0.338 & & 0.676 & & 1.000 \\
\hline Grass strip - meadow & & 0.041 & & 0.023 & & 0.492 & & 1.000 \\
\hline Grass strip - forest edge & & $<0.001$ & & $<0.001$ & & 0.022 & & 0.003 \\
\hline Fallow- meadow & & 0.959 & & 0.338 & & 0.504 & & 1.000 \\
\hline Fallow- forest edge & & $<\mathbf{0 . 0 0 1}$ & & $<\mathbf{0 . 0 0 1}$ & & 0.074 & & 0.006 \\
\hline Forest edge - meadow & & $<0.001$ & & 0.003 & & 0.504 & & 0.125 \\
\hline
\end{tabular}

(* Removed during backward model selection with AIC as indicator for the best model, no interactions between habitat type and percentage of arable land were detected.)

Generality, defined as the mean number of prey species per predator (Dormann et al. 2009) was highest on the forest edge and increased with increasing amount of arable land in the landscape in 2007 ( Table 4.2; Fig. 4.3b and 4.3g). Linkage density was also highest at the forest edge and positively correlated to the amount of arable land in 2007, whereas no influence of landscape complexity was observed in 2008 (Table 4.2;

Fig. 4.3c and 4.3h). Connectance of interaction links increased with decreasing landscape complexity in both years (Table 4.2; Fig. 4.3d and 4.3i). Connectance on fallows differed significantly from connectance on forest edges in 2007. Nestedness 
temperature, defined as the departure from systematic arrangement of species by niche width, was higher in fallows compared to forest edges and meadows in 2007 (Table 4.2; Fig. 4.3e).
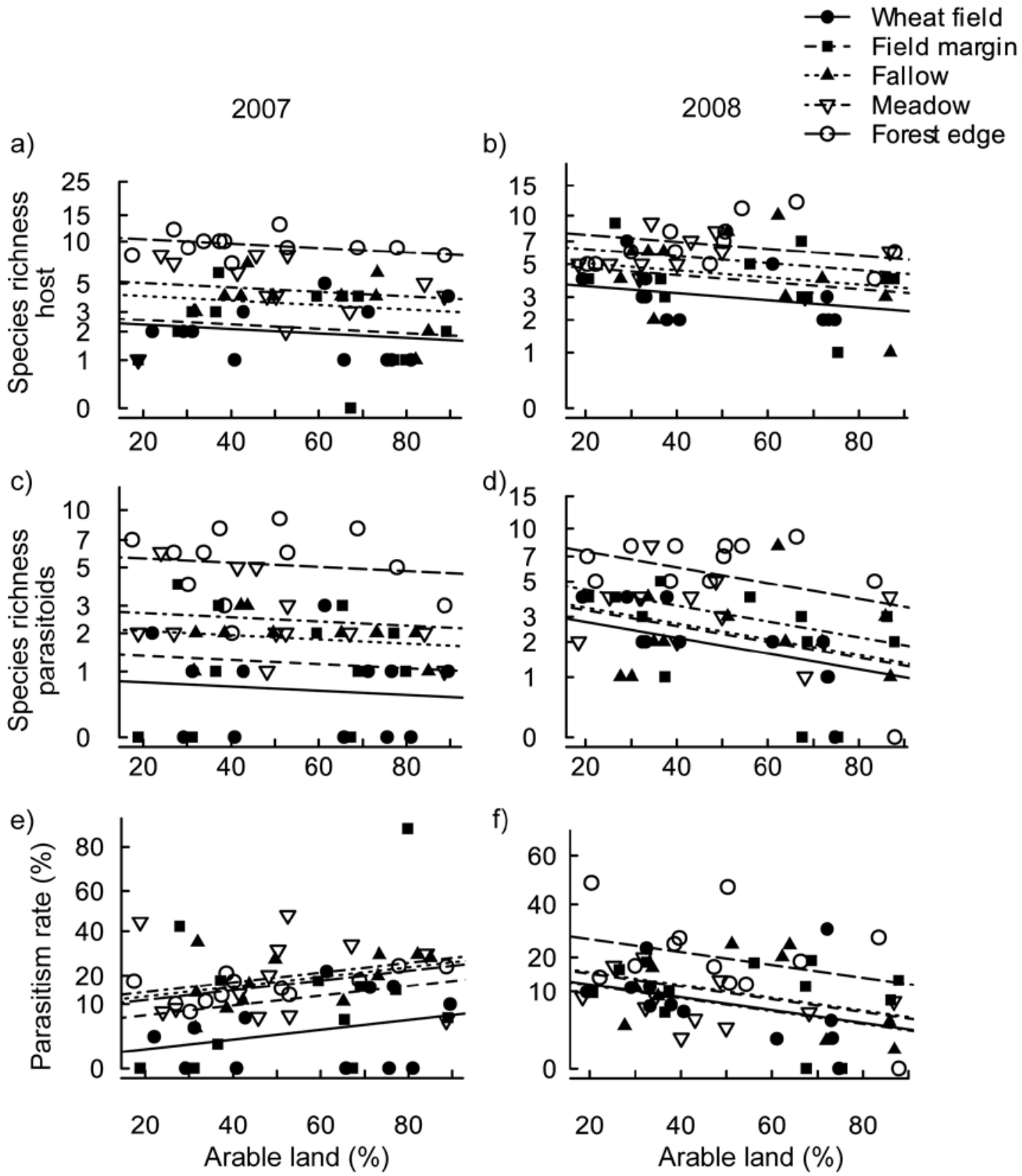

Figure 4.2 Influence of landscape complexity and different habitat types on the species richness of hosts in a) 2007 and d) 2008, species richness of parasitoids in b) 2007 and e) 2008 and the Parasitism rate (\%) in c) 2007 and f) 2008. 
Table 4.2 Results of the linear mixed-effects models, for the effects of landscape complexity (amount of arable land (\%)) and habitat on foodweb indices for the observed values and z- values (null models). Value of the full models were used for displaying non-significant results, while the best fitted model was used for significant values, by using backward model selection with AIC as indicator for the best model.

\begin{tabular}{|c|c|c|c|c|c|c|c|c|c|c|c|c|}
\hline \multirow{3}{*}{$\begin{array}{l}\text { Foodweb Indices } \\
\text { Shannon diversity }\end{array}$} & \multicolumn{3}{|c|}{2007} & \multicolumn{3}{|c|}{2007} & \multicolumn{3}{|c|}{2008} & \multicolumn{3}{|c|}{2008} \\
\hline & \multicolumn{3}{|c|}{ Observed values } & \multicolumn{3}{|c|}{ Z-values } & \multicolumn{3}{|c|}{ Observed values } & \multicolumn{3}{|c|}{ Z-Values } \\
\hline & DF & $\mathrm{F}$ & $\mathrm{P}$ & $\mathrm{DF}$ & $\mathrm{F}$ & $\mathrm{P}$ & DF & $\mathrm{F}$ & $\mathrm{P}$ & DF & $\mathrm{F}$ & $\mathrm{P}$ \\
\hline Amount arable land (\%) & 1,90 & 0.17 & 0.693 & 1,90 & 0.03 & 0.871 & 1,20 & 0.24 & 0.633 & 1,12 & 1.48 & 0.250 \\
\hline Habitat & 2,12 & 6.86 & 0.010 & 2,90 & 0.53 & 0.605 & 4,25 & 12.87 & $<0.001$ & 4,12 & 1.62 & 0.238 \\
\hline arable land (\%) x habitat & 1,90 & 0.30 & 0.745 & 2,90 & 1.74 & 0.230 & 4,20 & 0.29 & 0.880 & 4,12 & 0.42 & 0.793 \\
\hline \multicolumn{13}{|l|}{ Generality } \\
\hline Amount arable land (\%) & 1,11 & 6.97 & 0.023 & 1,90 & 0.03 & 0.860 & 1,24 & 0.79 & 0.382 & 1,16 & 2.96 & 0.038 \\
\hline Habitat & 2,11 & 4.88 & 0.031 & 2,90 & 0.23 & 0.792 & 4,24 & 7.05 & $<0.001$ & 4,16 & 2.26 & 0.108 \\
\hline arable land (\%) x habitat & 2,90 & 0.44 & 0.660 & 2,90 & 1.82 & 0.220 & 4,20 & 0.97 & 0.445 & 4,12 & 0.75 & 0.579 \\
\hline \multicolumn{13}{|l|}{ Linkage density } \\
\hline Amount arable land (\%) & 1,11 & 4.29 & 0.063 & 1,90 & $<0.01$ & 0.985 & 1,20 & 0.40 & 0.535 & 1,12 & 0.01 & 0.934 \\
\hline Habitat & 2,11 & 6.66 & 0.013 & 2,90 & 0.94 & 0.430 & 4, 25 & 4.74 & 0.004 & 4,12 & 1.08 & 0.411 \\
\hline arable land (\%) x habitat & 2,90 & 0.51 & 0.616 & 2,90 & 4.91 & 0.036 & 4,20 & 0.68 & 0.613 & 4,12 & 1.66 & 0.223 \\
\hline \multicolumn{13}{|l|}{$\begin{array}{l}\text { Mean number of } \\
\text { shared hosts }\end{array}$} \\
\hline Amount arable land (\%) & 1,13 & 9.80 & 0.008 & 1,90 & 0.30 & 0.60 & 1,20 & 1.26 & 0.276 & 1,11 & 5.81 & 0.035 \\
\hline Habitat & 2,90 & 0.30 & 0.745 & 2,90 & 0.26 & 0.778 & 4,20 & 1.55 & 0.225 & 4,11 & 4.58 & 0.020 \\
\hline arable land (\%) x habitat & 2,90 & 0.36 & 0.711 & 2,90 & 1.50 & 0.275 & 4,20 & 0.88 & 0.493 & 4,11 & 2.87 & 0.075 \\
\hline \multicolumn{13}{|l|}{$\begin{array}{l}\text { Mean number of } \\
\text { shared predators }\end{array}$} \\
\hline Amount arable land (\%) & 1,13 & 13.70 & 0.003 & 1,90 & 1.16 & 0.310 & 1,20 & 1.45 & 0.243 & 1,11 & 0.10 & 0.754 \\
\hline Habitat & 2,90 & 0.70 & 0.524 & 2,90 & 2.02 & 0.188 & 4,20 & 0.17 & 0.951 & 4,11 & 0.10 & 0.45 \\
\hline arable land (\%) x habitat & 2,90 & 0.99 & 0.410 & 2,90 & 4.70 & 0.040 & 4,20 & 1.78 & 0.172 & 4,11 & 3.13 & 0.060 \\
\hline \multicolumn{13}{|l|}{ Connectance } \\
\hline Amount arable land (\%) & 1,11 & 7.67 & 0.018 & 1,90 & 0.02 & 0.89 & 1,28 & 4.22 & 0.049 & 1,11 & 1.54 & 0.24 \\
\hline Habitat & 2,11 & 4.31 & 0.042 & 2,90 & 0.21 & 0.82 & 4,20 & 1.38 & 0.28 & 4,11 & 3.48 & 0.045 \\
\hline arable land (\%) x habitat & 2,90 & 1.43 & 0.289 & 2,90 & 2.17 & 0.17 & 4,20 & 0.46 & 0.77 & 4,11 & 1.85 & 0.190 \\
\hline \multicolumn{13}{|l|}{ Nestedness } \\
\hline Amount arable land (\%) & 1,90 & 0.28 & 0.610 & 1,90 & 0.02 & 0.891 & 1,20 & 0.14 & 0.710 & 1,11 & 1.43 & 0.257 \\
\hline Habitat & 2,12 & 5.25 & 0.023 & 2,90 & 4.88 & 0.037 & 4,20 & 1.66 & 0.198 & 4,11 & 0.12 & 0.971 \\
\hline arable land (\%) x habitat & 2,90 & 1.48 & 0.278 & 2,90 & 3.12 & 0.093 & 4, 20 & 1.51 & 0.236 & 4,11 & 2.66 & 0.090 \\
\hline
\end{tabular}




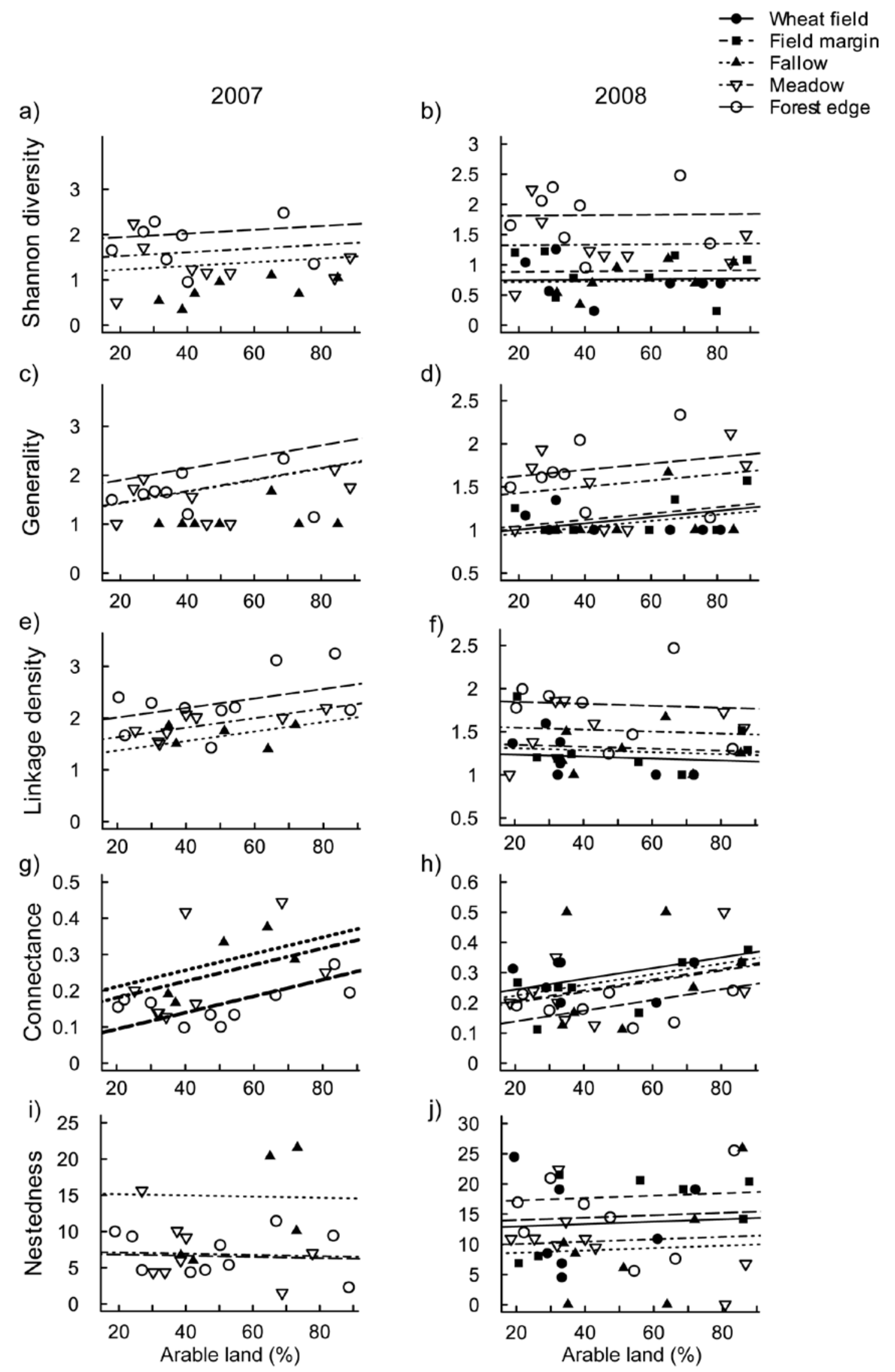

Figure 4.3 Effects of landscape complexity and habitat types on Shannon diversity (a \& b), generality (c \& d), linkage density (e \& f), connectance ( $\&$ \& $)$ and nestedness (i \& j) of the food webs in the year 2007 and in the year 2008. 


\section{CORRELATIONS BETWEEN VARIABLES AND FOOD WEB INDICES}

In both years host abundance, host species richness, parasitoid abundance and parasitoid species richness were all positively correlated, while parasitism rates were negatively correlated with host abundance (Table 4.3). The mean number of shared hosts was positively correlated with parasitism rates in both years (Table 4.3). Generality was positively correlated to the Shannon diversity in both years, mean number of shared hosts and linkage density in both years (Table 4.3). Mean number of shared hosts was positively correlated with mean number of shared predators and both indices were positively correlated with connectance and linkage density in both years (Table 4.3).

\section{COMPARISON OF OBSERVED-AND NULL MODELS (Z-VALUES)}

We compared the results, derived from lmes with observed values, with the lmes, using the z-values instead of observed values in the models, to see whether expected and observed effects of landscape habitat and landscape complexity were equal. In 2007 the habitat effect for fallow on nestedness was also detected, using the z-values in the model. Positive interactions between the meadow and the amount of arable land were detected for generality and mean number of shared hosts in 2007 (Table 4.2). In 2008 the amount of arable land had a positive influence on generality and a negative impact on mean number of shared hosts (Table 4.2). Connectance and the mean number of shared hosts were highest in the wheat field, compared to the fallow in 2008 (Table 4.2). 
Table 4.3 Correlation matrix for abundances and species richness of host \& parasitoids, parasitism rates (\%) and food web indices of the two years, deriving from Pearson's product moment correlation. Given values are $\left(r_{\mathrm{P}}\right)$, bold printed values indicate significance $(\mathrm{P}<0.05)$. The upper triangle represents the values for 2007 , lower triangel represents values for 2008 .

\begin{tabular}{|c|c|c|c|c|c|c|c|c|c|c|c|c|}
\hline 2008 & $\left|\begin{array}{c}\text { Host } \\
\text { abundanc } \\
\text { e }\end{array}\right|$ & $\begin{array}{c}\text { Parasitism } \\
\text { rate }\end{array}$ & $\begin{array}{c}\text { Host } \\
\text { Species } \\
\text { richness }\end{array}$ & $\begin{array}{c}\text { Parasitoid } \\
\text { species } \\
\text { richness }\end{array}$ & $\begin{array}{l}\text { Parasitoid } \\
\text { abundance }\end{array}$ & $\begin{array}{l}\text { Shannon } \\
\text { index }\end{array}$ & Generality & $\begin{array}{c}\text { Mean no. } \\
\text { shared hosts }\end{array}$ & $\begin{array}{c}\text { Mean no. } \\
\text { shared } \\
\text { predators }\end{array}$ & Connectance & $\begin{array}{l}\text { Linkage } \\
\text { density }\end{array}$ & Nestedness \\
\hline Host abundance & 1 & -0.67 & 0.9 & 0.69 & 0.7 & -0.5 & -0.42 & -0.1 & -0.08 & 0.06 & -0.41 & -0.42 \\
\hline Parasitism rate & -0.43 & 1 & -0.65 & -0.28 & 0.05 & 0.55 & 0.32 & 0.36 & 0.09 & 0.11 & 0.43 & 0.36 \\
\hline $\begin{array}{l}\text { Host species } \\
\text { richness }\end{array}$ & 0.54 & -0.07 & 1 & 0.69 & 0.59 & -0.37 & -0.34 & -0.11 & -0.12 & 0 & -0.36 & -0.29 \\
\hline $\begin{array}{l}\text { Parasitoid species } \\
\text { richness }\end{array}$ & 0.46 & 0.12 & 0.65 & 1 & 0.64 & -0.31 & -0.45 & -0.45 & 0.01 & -0.16 & 0.13 & -0.29 \\
\hline \begin{tabular}{|l} 
Parasitoid \\
abundance
\end{tabular} & 0.57 & 0.42 & 0.46 & 0.61 & 1 & -0.16 & -0.24 & 0.26 & 0.01 & 0.25 & -0.13 & -0.16 \\
\hline Shannon index & 0.11 & 0.19 & 0.53 & 0.82 & 0.31 & 1 & 0.75 & 0.24 & 0.29 & -0.31 & 0.84 & 0.01 \\
\hline Generality & -0.01 & 0.43 & 0.35 & 0.5 & 0.34 & 0.78 & 1 & 0.48 & 0.49 & -0.02 & 0.84 & 0.14 \\
\hline $\begin{array}{l}\text { Mean number } \\
\text { shared hosts }\end{array}$ & -0.11 & 0.47 & -0.02 & 0.14 & 0.26 & 0.43 & 0.73 & 1 & 0.62 & 0.79 & 0.55 & 0.28 \\
\hline $\begin{array}{l}\text { Mean number } \\
\text { shared predators }\end{array}$ & -0.06 & 0.25 & -0.21 & -0.01 & 0.15 & 0.11 & 0.28 & 0.43 & 1 & 0.37 & 0.68 & -0.17 \\
\hline Connectance & -0.54 & 0.28 & -0.79 & -0.54 & -0.31 & -0.25 & 0.12 & 0.46 & 0.44 & 1 & 0.01 & 0.4 \\
\hline Linkage density & 0.11 & 0.29 & 0.38 & 0.66 & 0.38 & 0.85 & 0.83 & 0.56 & 0.51 & -0.02 & 1 & -0.09 \\
\hline Nestedness & 0.09 & -0.13 & -0.2 & 0.21 & 0.02 & 0.01 & -0.29 & -0.27 & -0.53 & -0.12 & -0.26 & 1 \\
\hline
\end{tabular}




\section{DISCUSSION}

In this study we compared host-parasitoid food webs of trap-nesting bees, wasps and their parasitoids in five different habitats over a landscape complexity gradient and two years. Food webs differed strikingly over the five different habitats. Our first hypothesis was confirmed: i) abundance and species richness of hosts and parasitoids, Shannon diversity of interactions and linkage density were higher in high-quality habitats, especially at the forest edge, compared to the low-quality habitats such as wheat field and adjacent field strip. This shows that high-quality and semi-natural habitats are essential as source habitats for trap-nesting bees and wasps and their parasitoids. These habitats play an important role in maintaining diversity (SteffanDewenter 2002) and secure interaction links. Forest edges are known to be valuable habitats, offering food and nesting resources (Holzschuh, Steffan-Dewenter \& Tscharntke 2009). Taki, Kevan and Ascher (2007) found a positive correlation of pollinator abundances and amount of forest in the landscape. The structure of ecological communities is assumed to be mediated by resource competition, such as food supply, nesting opportunities or the supply of hosts (Burkonvinszky et al. 2008). The findings of previous studies is in line with this assumption, since abundance and species richness of trap-nesting bees and wasps is limited by the availability of nesting sites in the habitat (Gathmann, Greiler \& Tscharntke 1994; Tscharntke, Gathmann \& Steffan-Dewenter 1998; Steffan-Dewenter 2003). Forest edges inherit hedges and deadwood such as tree trunks offering numerous nesting sites to above ground-nesting bees and predatory wasps.

Food webs in low-quality habitats (wheat field and field margin) contained only few species and few but strong interactions. McCann (2000) emphasizes in his review that strong consumer-resource interactions are potentially destabilizing communities. Following the insurance hypothesis (Yachi \& Loreau 1999), the extinction risk of species is supposed to be lower in large food webs with many species, since it is more likely that different species react differently to disturbances and functional redundancy is more likely to appear in diverse communities (Naeem \& Li 1997; Levin 1998). In our study a decrease in biodiversity led to fewer but stronger interactions. The high values for linkage density on the forest edge imply that food webs are more stable in high quality habitats. Parasitism rates were negatively correlated to host species richness in 2007, which is in line with the findings of 
Hillebrand and Cardinale (2004), who showed that increasing the diversity of prey items, in our case hosts, levels consumer effects. Generality was positively correlated with linkage density and the mean number of shared hosts and predators also emphasizing the value of forest edge as diverse habitat.

Our initial hypotheses ii) and iii) were confirmed: ii) in both years decreasing landscape complexity had a negative impact on abundance and species richness of hosts and their parasitoids and parasitism rates (except abundance of hosts and parasitoids in 2007 and species richness of parasitoids in 2008) and iii) decreasing landscape complexity promoted generality, in both years. Besides focussing on resource availability as driver of community interactions, predator-prey assemblages may be more dominated by the phenomenon of apparent competition (Holt 1977), meaning two prey species share the same predator which benefits from having an alternative prey. The positive effects of increasing amount of arable land on generality, shared hosts and predators in 2007 show that even in high quality habitats a decrease of landscape complexity in the surrounding environment may have a considerable effect on host-parasitoid communities, by increasing the number of host species per parasitoid, which enhances the possibility of apparent competition in the community (Morris, Lewis \& Godfray 2005). The shared parasitoid of two or more species is going to benefit from higher resource availability, while the host that is weaker in abundance, compared to other(s) may be weakened or get extinct by the increasing attack rates and abundances of parasitoids. This assumption is in line with connectance increasing with increasing amount of arable land and being highest on fallows, compared to forest edges in 2007, indicating that combinations of species interactions tend to be higher in less structured landscapes and or less diverse habitats (see 2007), where less species occur. Morris, Lewis and Godfray (2004) assumed that the potential for indirect effects of apparent competition on community structure increases with connectivity. In 2008 landscape complexity influenced connectance, and generality positively, as well and parasitism rates were positively correlated with generality, and the mean number of shared hosts in both years. Our results imply that poorly structured landscapes are likely to promote apparent competition in food web interactions, which may exacerbate species loss in these areas.

Interactions of food webs in 2008 were clearly dominated by Osmia rufa, but habitat effects on Shannon diversity, generality and linkage density were even more pronounced than 2007. Since interaction diversity was negatively correlated to host 
and parasitoid species richness in 2007 and the correlation turned positively in 2008, it seems that in 2007 the occurring species tended to be more generalistic than 2008 . Osmia rufa was attacked by three specialist parasitoids (Anthrax anthrax, Cacoxenus indagator and Monodontomerus obsoletus, Fig. 4.1, Species numbers 1, 2 and 12), which could blur similar effects compared to 2007 for food web metrics, by alleviating effects of nestedness and the number of shared hosts.

Nestedness temperature was highest on the fallow, indicating lower overlap of species niche width, compared to forest edge and meadow. The lower the nestedness temperature, the greater is the similarity of different species interactions. Previous studies showed that mutualistic networks are highly nested and that nested structure enhances biodiversity in mutualistic communities (Bascompte et al. 2003, Ollerton et al. 2007). Kondoh, Kato \& Sakato (2010) argue that nested structure in food webs is common in resource-consumer interactions and that increased niche overlap among consumers may impede coexistence. A recent study by Thébault \& Fontaine (2010) shows that stability of trophic networks is enhanced by weak connectance and compartments instead of nestedness. In our case this would result in higher stability of communities on fallows, yet the interpretation of nestedness in food web remains an issue in future research and may therefore be taken cautiously (Ings et al. 2009; Joppa et al. 2010; Tylianakis et al. 2010).

The expected values of effects on food web metrics differed from the observed values, except the habitat influence on nestedness temperature in 2007, underlining the effects of habitat quality on niche arrangement of parasitoid-host communities. The changes of interactions in the observed food webs are very likely an outcome of alteration of species assemblages in the consecutive years, since the models for expected and observed values differed in their significance. However, despite the population shifts in the two years we assessed equal effects concerning study site and landscape complexity on the species richness of hosts and parasitoids, Shannon diversity, generality and connectance in both years. 


\section{CONCLUSIONS}

Our results show that species and interaction diversity and related indices are strongly influenced by local resources (habitat), while decreasing landscape complexity alters interactions, especially in more generalistically structured communities.

High quality habitats, hosting a variety of flowering plants accounting for food supply and appropriate nesting sites are necessary for maintaining species richness of hosts and parasitoids and therefore stable networks. Decreasing landscape complexity leads to alteration of network interactions, which is likely to result in their destabilization and imperils pollination services and biological control in agricultural landscapes. 


\section{ACKNOWLEDGEMENTS}

We thank Susanne Schiele for support during field work and for dissecting the trap nests and needling the emerging individuals in both years, Jochen Fründ for statistical advice and helpful comments on this manuscript, the farmers for the usage of their fields, fallows and meadows as experimental sites. Ines Vollhardt for support during the field work in 2007 and Stefan Hellmich for GIS calculations in 2008. This research was funded by the Helmholtz Association (VH-NG-247). 


\section{REFERENCES}

Aickin, M., Gensler, H. (1996) Adjusting for multiple testing when reporting research results: The Bonferroni vs Holm methods. American Journal of Public Health, 86, $726-728$.

Albrecht, M., Duelli, P., Schmid, B. \& Müller, C.B. (2007) Interaction diversity within quantified insect food webs in restored and adjacent intensively managed meadows. Journal of Animal Ecology, 76, 1015- 1025.

Altieri, M.A. (1999) The ecological role of biodiversity in agroecosystems. Agriculture, Ecosystems \& Environment, 74, 19-31.

Banasek-Richter, C., Cattin, M. \& Bersier, L. (2004) Sampling effects and the robustness of quantitative and qualitative food-web descriptors. Journal of Theoretical Biology, 226, 23-32.

Bascompte, J., Jordano, P., Melian, C.J. \& Olesen, J.M. (2003) The nested assembly of plant-animal mutualistic networks. Proceedings of the National Academy of Sciences of the United States of America, 100, 9383-9387.

Benton, TG., Vickery, J.A. \& Wilson, J.D. (2003) Farmland biodiversity: is habitat heterogeneity the key? Trends in Ecology and Evolution, 18, 182- 188.

Biesmeijer, J.C., Roberts, S.P.M., Reemer, M., Ohlemüller, R., Edwards, M., Peeters, T., Schaffers, A.P., Potts, S.G., Kleukers, R., Thomas, C.D., Settele, J. \& Kunin, W.E. (2006) Parallel declines in pollinators and insect-pollinated plants in Britain and the Netherlands. Science, 313, 351-354.

Blüthgen, N., Fründ, J., Vázquez, D.P. \& Menzel, F. (2008) What do interaction network metrics tell us about specialization and biological traits? Ecology, 89, $3387-99$.

Borrvall C., Ebenman, B. \& Jonsson, T. (2000) Biodiversity lessens the risk of cascading extinction in model food webs. Ecology Letters, 3, 131- 136. 
Bukovinszky, T., van Veen, F., Jongema, Y. \& Dicke, M. (2008) Direct and indirect effects of resource quality on food web structure. Science, 319, 804-807.

Cane, J.H. (1997) Ground nesting bees: the neglected pollinator resource for agriculture. Acta Horticulturae, 437, 309- 324.

Danks, H. V. (1970) Biology of some stem-nesting aculeate Hymenoptera. Transactions of the Royal Entomological Society of London, 122, 323- 395.

Daily, G. (1997) Nature's services: societal dependence on natural ecosystems. Island Press, Washington, D.C., USA.

Davies, K., Margules, C. \& Lawrence, K. (2000) Which traits of species predict population declines in experimental forest fragments? Ecology, 81, $1450-1461$.

Dormann, C.F., Fründ, J., Blüthgen, N. \& Gruber, B. (2009) Indices, graphs and null models: analyzing bipartite ecological networks. The Open Ecology Journal, 2, $7-24$.

Gathmann, A., Greiler, H.-J. \& Tscharntke, T. (1994) trap-nesting bees and wasps colonizing set-aside fields: Succession and body size, managment by cutting and sowing. Oecologia, 98, 8- 14 .

Henson, K.S.E., Craze, P.G. \& Memmott, J. (2009) The restoration of parasites, parasitoids, and pathogens to heathland communities. Ecology, 90, $1840-1851$.

Hillebrand, H. \& Cardinale, B.J. (2004) Consumer effects decline with prey diversity. Ecology Letters, 7, $192-201$.

Holt, R.D. (1977) Predation, apparent competition, and the structure of prey communities. Theoretical population Biology, 12, 197-229.

Holt, R.D. \& Lawton, J.H. (1993) Apparent competition and enemy-free space in insect host-parasitoid communities. The American Naturalist, 142, 623-645. 
Holzschuh, A., Steffan-Dewenter, I. \& Tscharntke, T. (2009) Grass strip corridors in agricultural landscapes enhance nest-site colonization by solitary wasps. Ecological Applications, 19, 123-132.

Holzschuh, A., Steffan-Dewenter, I. \& Tscharntke, T. (2010) How do landscape composition and configuration, organic farming and fallow strips affect the diversity of bees, wasps and their parasitoids? Journal of Animal Ecology, 79, $491-500$.

Ings, T.C., Montoya, J.M., Bascompte, J., Bluthgen, N., Brown, L., Dormann, C.F., Edwards, F., Figueroa, D., Jacob, U., Jones, J.I., Lauridsen, R.B., Ledger, M.E., Lewis, H.M., Olesen, J.M., van Veen, F.J.F., Warren, P.H. \& Woodward, G. (2009) Ecological networks - beyond food webs. Journal of Animal Ecology, 78, $253-269$.

Joppa, L.N., Montoya, J.M., Sole, R., Sanderson, J. \& Pimm, S.L. (2010) On nestedness in ecological networks. Evolutionary Ecology Research, 12, 35- 46.

Klein, A., Steffan-Dewenter, I. \& Tscharntke, T. (2006) Rain forest promotes trophic interactions and diversity of trap-nesting hymenoptera in adjacent agroforestry. Journal of Animal Ecology, 75, 315-323.

Klein A.M., Vaissière B.E., Cane J.H., Steffan-Dewenter I., Cunningham S.A., Kremen C. \& Tscharntke T. (2007) Importance of pollinators in changing landscapes for world crops. Proceedings of the Royal Society B - Biological Sciences, 274, 303- 313.

Kondoh, K., Kato, S. \& Sakato, Y. (2010) Food webs are built up with nested subwebs. Ecology, 91, 3123- 3130.

Kremen, C., Williams, N.M. \& Thorp, R.W. (2002) Crop pollination from wild bees at risk from agricultural intensification. Proceedings of the National Academy of Scienes of the United States of America, 99, 16812- 16816.

Kruess, A. \& Tscharntle, T. (2000) Species richness and parasitism in a fragmented landscape: experiments and field studies with insects on Vicia sepium. Oecologia, 122, 129- 137. 
Krewenka, K.M., Holzschuh, A, Tscharntke, T. \& Dormann, C.F. (2011) Landscape elements as potential barriers and corridors for bees, wasps and parasitoids. Biological Conservation, DOI:10.1016/j.biocon.2011.03.014.

Levin, S.A. (1998) Biosphere as Complex Adaptive Systems. Ecosystems, 1, $431-436$.

Lewis, O.T., Memmot, J., Lasalle, .J., Lyal, C.H.C., Whitefoord, C. \& Godfray, H.C.J. (2002) Structure of a diverse tropical forest insect-parasitoid community. Journal of Animal Ecology, 71, 855-873.

McCann, K.S. (2000) The diversity-stability debate. Nature, 405, 228-233.

Morris, R., Lewis, O. \& Godfray, H. (2004) Experimental evidence for apparent competition in a tropical forest food web. Nature, 428, 310-313.

Morris, R., Lewis, O.T. \& Godfray, H.C.J. (2005) Apparent competition and insect community structure: towards a spatial perspective. Annales Zoologici Fennici, 42, $449-462$.

Müller, C.B., Adriaanse, I.C.T., Belshaw, R. \& Godfray, H.C.J. (1999)The structure of an aphid-parasitoid community. Journal of Animal Ecology, 68, 346-370.

Naeem, S. \& Li, S. (1997) Biodiversity enhances ecosystem reliability. Nature, 390, $507-509$.

Ollerton, J., McCollin, D., Fautin, D.G. \& Allen, G.R. (2007) Finding NEMO: nestedness engendered by mutualistic organization in anemonefish and their hosts. Proceedings of the Royal Society B - Biological Sciences, 274, 591 -598.

Pimm, S.L. (1991) The Balance of Nature? Ecological Issues in the Conservation of Species and Communities. University of Chicago Press, Chicago, IL, USA.

Pinheiro, J., Bates, D., DebRoy, S., Sarkar, D \& the R Development Core Team (2009) nlme: Linear and Nonlinear Mixed Effects Models. R package version 3.1-96. 
Potts, S.G., Roberts, S.P.M., Dean, R., Marris, G., Brown, M., Jones, R. \& Settele, J. (2010) Declines of managed honeybees and beekeepers in Europe. Journal of Apicultural Research, 49, 15- 22.

R Development Core Team (2010) A Language and Environment for Statistical Computing, R Foundation for Statistical Computing, Vienna, Austria.

Roschewitz, I., Thies, C. \& Tscharntke, T. (2005) Are landscape complexity and farm specialisation related to land-use intensity of annual crop fields? Agriculture, Ecosystems and Environment, 105, 87- 99.

Ricketts, T.H., Regetz, J., Steffan-Dewenter, I., Cunningham, S.A., Kremen, C., Bogdanski, A., Gemmill-Herren, B., Greenleaf, S.S., Klein, A.M., Mayfield, M.M., Morandin, L.A., Ochieng, A. \& Viana, B.F. (2008) Landscape effects on crop pollination services: are there general patterns? Ecology Letters, 11, 499-515.

Schmidt, M.H., Thies, C. \& Tscharntke, T. (2004) Landscape context of arthropod biological control. Ecological Engineering for Pest Management: Advances in Habitat Manipulation for Arthropods (eds. G. Gurr, S. Wratten \& M. Altieri) pp. 55-63. CSIRO Press, Collingwood, Australia.

Solé, R.V. \& Montoya, M. (2001) Complexity and fragility in ecological networks. Proceedings of the Royal Society London B., 268, 2039-2045.

Steffan-Dewenter, I. (2002) Landscape context affects trap-nesting bees, wasps, and their natural enemies. Ecological Entomology, 27, 631-637.

Steffan-Dewenter, I. (2003) Importance of habitat area and landscape context for species richness of bees and wasps in fragmented orchard meadows. Conservation Biology, 17, 1036- 1044.

Steffan-Dewenter, I. \& Schiele, S. (2008) Do resources or natural enemies drive bee population dynamics in fragmented habitats? Ecology, 89, 1375-1387.

Taki, H., Kevan, P.G. \& Ascher, J.S. (2007) Landscape effects of forest loss in a pollination system. Landscape Ecology, 22, 1575- 1587. 
Thébault, E. \& Loreau, M. (2006) The relationship between biodiversity and ecosystem functioning in food webs. Ecological Research, 21, 17-25.

Thébault, E. \& Fontaine, C. (2010) Stability of ecological communities and the architecture of mutualistic and trophic networks. Science, 329, 853-856.

Tilman, D., Fargione, J., Wolff, B., D'Antonio, C., Dobson, A., Howarth, R., Schindler, D., Schlesinger, W.H., Simberloff, D. \& Swackhamer, D. (2001) Forecasting agriculturally driven global environmental change. Science, 292, $281-284$.

Tscharntke, T., Gathmann, A. \& Steffan-Dewenter, I. (1998) Bioindication using trapnesting bees and wasps and their natural enemies: community structure and interactions. Journal of Applied Ecology, 35, 708-719.

Tylianakis, J.M., Tscharntke, T. \& Klein, A.M. (2006) Diversity, ecosystem function, and stability of parasitoid host interactions across a tropical habitat gradient. Ecology, 87, 3047-3057.

Tylianakis, J.M., Tscharntke, T. \& Lewis, O.T. (2007) Habitat modification alters the structure of tropical host-parasitoid food webs. Nature, 445, 202- 205.

Tylianakis, J.M., Laliberte, E., Nielsen, A. \& Bascompte, J. (2010) Conservation of species interaction networks. Biological Conservation, 143, 2270-2279.

van Nouhuys, S. (2005) Effects of habitat fragmentation at different trophic levels in insect communities. Annales Zoologici Fennici, 42, 433-447.

Veddeler D., Tylianakis, J., Tscharntke, T. \& Klein, A.M. (2010) Natural enemy diversity reduces temporal variability in wasp but not bee parasitism. Oecologia, 162, 755-762.

Watanabe, M.E. (1994) Pollination worries rise as honey-bees decline. Science, 265, $1170-1170$.

Westrich, P. (1989) Die Wildbienen Baden-Würtembergs: Spezieller Teil. Verlag Eugen Ulmer, Stuttgart, Germany. 
Wetterstation Göttingen online, Available at: http://www.wetterstation-göttingen.de (accessed 05 Apr 2011)

Winfree, R., Williams, N.M., Dushoff, J. \& Kremen, C. (2007) Native bees provide insurance against ongoing honey bee losses. Ecology Letters, 10, 1105-1113.

Yachi, S. \& Loreau, M. (1999) Biodiversity and ecosystem productivity in a fluctuating environment: The insurance hypothesis. Proceedings of the National Academy of Sciences, 96, 1463- 1468. 


\section{APPENDIX}

A4.1 Numbers for identification of individuals shown in the quantitative food webs.

\begin{tabular}{|c|c|c|c|c|}
\hline Host & Species & & Parasitoid & Species \\
\hline 1 & Ancistrocerus & antilope & 1 & Anthrax anthrax \\
\hline 2 & Ancistrocerus & gazella & 2 & Cacoxenus indagator \\
\hline 3 & Ancistrocerus & nigricornis & 3 & Chrysis ignita \\
\hline 4 & Ancistrocerus & parietum & 4 & Chrysis sp. \\
\hline 5 & Ancistrocerus & trifasciatus & 5 & Gasteruption assectator \\
\hline 6 & Anthophora & furcata & 6 & Gasteruption jaculator \\
\hline 7 & Anthophora & sp. & 7 & Gasteruption sp. \\
\hline 8 & Auplopus & carbonarius & 8 & Ichneumonidae sp. \\
\hline 9 & Auplopus & sp. & 9 & Megatoma undata \\
\hline 10 & Chelostoma & florisomne & 10 & Melittobia acasta \\
\hline 11 & Chelostoma & rapunculi & 11 & Mites \\
\hline 12 & Chelostoma & sp. & 12 & Monodontomerus obsoletus \\
\hline 13 & Crossocerus & cetratus & 13 & Pseudomalus auratus \\
\hline 14 & Dipogon & subintermedius & 14 & Sapyga clavicornis \\
\hline 15 & Dipogon & sp. & 15 & Trichrysis cyanea \\
\hline 16 & Discoelius & zonalis & 16 & Unidentified parasitoid 1 \\
\hline 17 & Eumeninae & sp. & 17 & Unidentified parasitoid 2 \\
\hline 18 & Heriades & truncorum & & \\
\hline 19 & Hylaeus & communis & & \\
\hline 20 & Hylaeus & confusus & & \\
\hline 21 & Hylaeus & sp. & & \\
\hline 22 & Megachile & alpicola & & \\
\hline 23 & Megachile & centuncularis & & \\
\hline 24 & Megachile & versicolor & & \\
\hline 25 & Megachile & sp. & & \\
\hline 26 & Nitela & sp. & & \\
\hline 27 & Osmia & brevicornis & & \\
\hline 28 & Osmia & leaiana & & \\
\hline 29 & Osmia & leucomelana & & \\
\hline 30 & Osmia & rufa & & \\
\hline 31 & Osmia & sp. & & \\
\hline 32 & Passaloecus & brevilabris & & \\
\hline 33 & Passaloecus & corniger & & \\
\hline 34 & Passaloecus & eremita & & \\
\hline 35 & Passaloecus & gracilis & & \\
\hline 36 & Passaloecus & sp. & & \\
\hline 37 & Pemphredon & lethifera & & \\
\hline 38 & Pemphredon & lugubris & & \\
\hline 39 & Psenulus & pallipes & & \\
\hline 40 & Symmorphus & bifasciatus & & \\
\hline 41 & Symmorphus & crassicornis & & \\
\hline 42 & Symmorphus & gracilis & & \\
\hline 43 & Symmorphus & murarius & & \\
\hline 44 & Trypoxylon & clavicerum & & \\
\hline 45 & Trypoxylon & figulus & & \\
\hline 46 & Trypoxylon & medium & & \\
\hline 47 & Trypoxylon & minus & & \\
\hline 48 & Trypoxylon & sp. & & \\
\hline
\end{tabular}




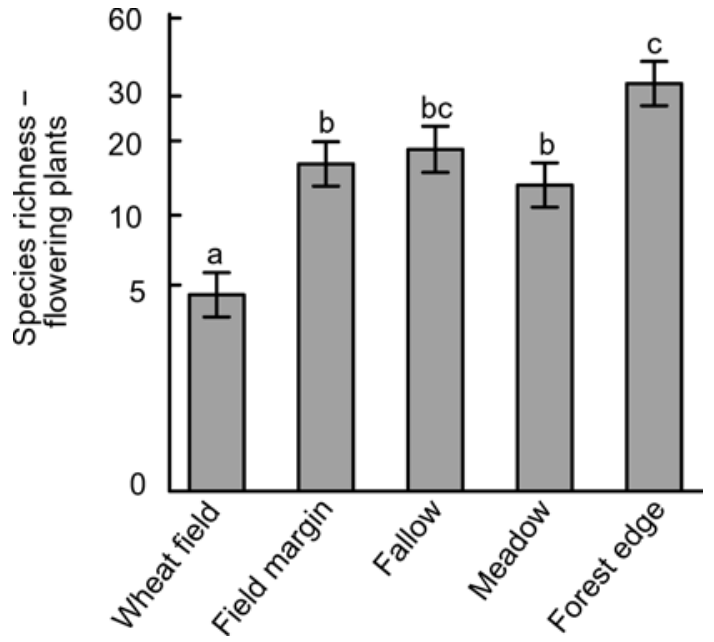

A4.2 Species richness of flowering plants on the different study sites.

Given are the mean values \pm SEM. 
S

\section{SUMMARY}

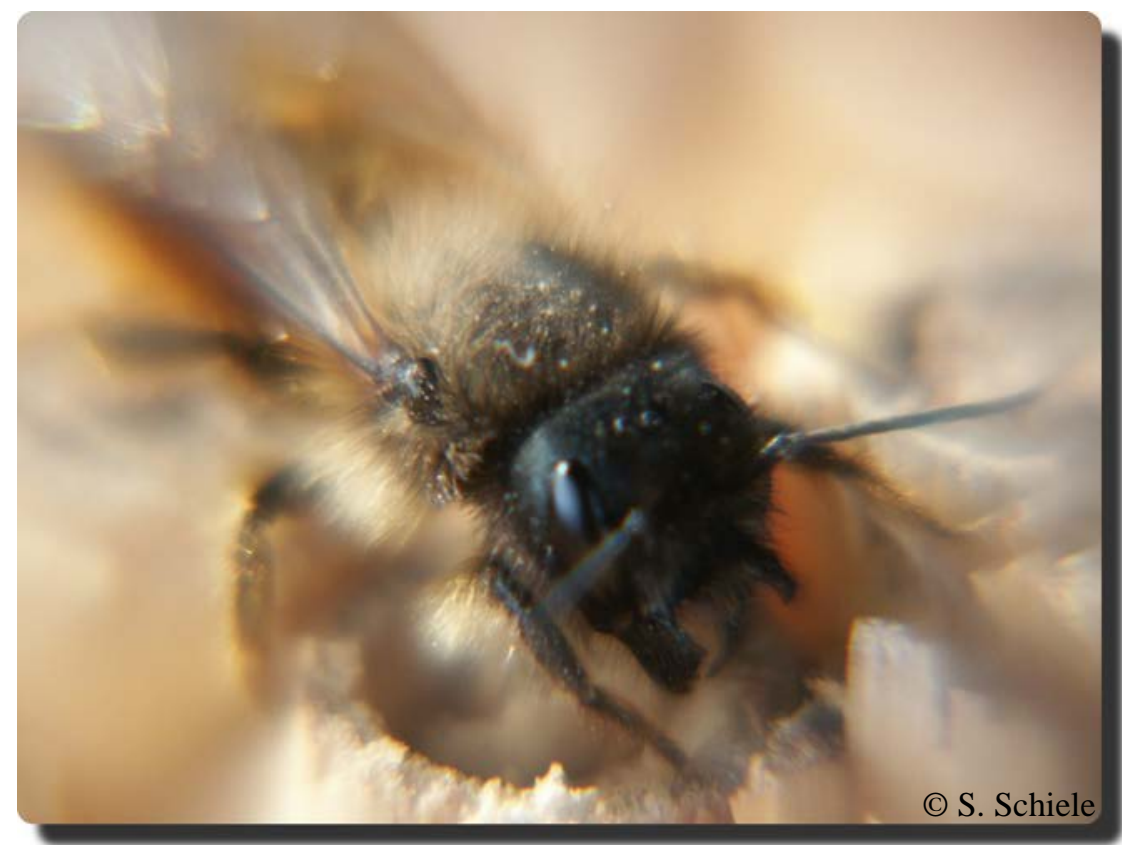




\section{SUMMARY}

The world population is growing, resulting in an increasing demand for food and energy plants. During the last decades the modification of landscapes into agricultural production units and the intensification of agricultural practises have led to a decline in biodiversity. Biodiversity is crucial for the stability of ecosystem services driven by biotic interactions, such as pollination and biological control. Pollination is important for reproduction of wild plants and it is estimated that $75 \%$ of the world crops need animal pollination for obtaining optimal yields. In the northern hemisphere bees are the most important pollinators in the agricultural landscape. But there is evidence that we are facing a pollinator crisis since managed honey bees as well as wild bee populations are declining, especially in intensively managed areas. Agricultural intensification affects also predatory wasps, which are contributing to biological control of pest species. Parasitoids play an important role in regulating host species. Biodiversity loss of functionally important groups such as pollinators, predators and parasitoids can destabilize trophic interactions leading to cascading extinctions.

The aim of this study was to quantify the impact of different landscape elements and habitat types, which are common in the agricultural landscape, on the communities of bees, wasps and their parasitoids with changing importance of habitat type along a gradient of landscape complexity. The study was carried out in the vicinity of the city of Göttingen, Lower Saxony, Germany.

In the first part of this thesis I tested the hypothesis that grassy field margin strips can function as corridors, facilitating the movement of hymenopterans and antagonists in the agricultural landscape. Additionally possible barrier effects of dense hedges, which were hypothesized to inhibit the movement of wild bees, were tested. Species-rich calcareous grasslands were taken as source habitats for bees, wasps and their parasitoids and connected and unconnected grass strips in varying distances were chosen to account for possible corridor effects on abundance and species richness, whereas dense hedges at the edge of the grasslands were expected to be barriers for foraging bees. Foraging bees were monitored using pan traps, while above-nesting bees, wasps and their parasitoids were experimentally analysed using standardized nesting resources (trap nests). The results showed that grassy strips can function as alternative nesting and foraging habitats when semi-natural habitats are nearby. I found strong isolation effects for nearly all observed groups. Abundance and species 
richness of foraging solitary bees, above ground-nesting bees, wasps and parasitoids declined with increasing distance to the calcareous grassland. Bumblebees were an exception to this, showing no decline in abundance or species richness. The hypotheses that grass strip corridors mitigate the tested $100 \mathrm{~m}$ isolation effects on any of the observed groups and that hedges function as barriers on the foraging bees had to be rejected.

In the second part of this thesis the relative importance of different land use types, landscape attributes (percent fallows and semi-natural habitats) and landscape complexity on species richness and abundance of pollinators was assessed over a time span of three years. Five habitat types that are common in the agricultural landscapes, namely (i) wheat field, ii) grassy field margin strip, iii) meadow, iv) fallow and v) forest edge were chosen in 12 non-overlapping landscape sectors with a radius of $1000 \mathrm{~m}$ around each habitat. These landscapes covered a gradient in landscape complexity, which was measured as amount of arable land ranging from structurally complex (14\% of arable land) to structurally poor (89\% of arable land). Pollinator populations in the different habitats were monitored, using pan traps for foraging bees in three years and standardized trap nests for above-nesting bees in two years. Abundance and species richness of the observed ground-nesting bee groups were primarily affected by landscape attributes, rather than habitats, while above groundnesting bees were mainly influenced by habitats. In the three study years the amount of fallows declined more than $50 \%$ in the landscapes. Abundance and species richness of solitary ground-nesting bees declined over the years as well, while the abundance and species richness of above ground-nesting bees remained stable. As hypothesized, abundance of bumblebees was positively influenced by the amount of fallow in the landscape. Species richness of bumblebees and abundance and species richness of solitary ground-nesting bees, as well as abundance of above ground-nesting bees showed a positive response to the amount of semi-natural habitats in the landscape. Abundance and species richness of above ground-nesting bees was positively influenced by higher quality habitats, hosting higher numbers of plant species, than intensively managed habitats (wheat field and field margin strip).

The third study was based on the previous, using the same design to assess the effects of habitat types and landscape complexity on the trophic interactions and food web structure of bees, wasps and their natural enemies in the trap nests in two years. Abundance and species richness of the observed groups were lowest in intensively 
managed habitats (wheat field and field margin strip). Parasitism rates were higher in high quality habitats (forest edge) in both years, though species composition varied. Shannon diversity and linkage density of interactions in the food webs were negatively affected by low habitat quality. Interestingly, the connectance of species interactions, as a measure of food web complexity and generality of interactions, increased with decreasing landscape complexity, which may result in enhanced consumer effects in simple landscapes.

In conclusion, bees, wasps and their parasitoids depend strongly on high-quality habitats, such as extensively managed grasslands and forest edges as source habitats in the landscape, but have the ability to use alternative foraging and nesting sites of lower quality, if these are supported by a certain amount of semi-natural habitats in the surrounding. Intensively used habitats, such as arable fields and field margin strips, and decreasing landscape complexity affect abundance and diversity of pollinators, predators and parasitoids negatively and alter their interactions. The results of the studies show that conservation of semi-natural habitats is essential to maintain viable populations of bees, wasps and parasitoids in the agricultural landscape and ensure ecosystem services provided by them. 


\section{Z}

ZUSAMMENFASSUNG

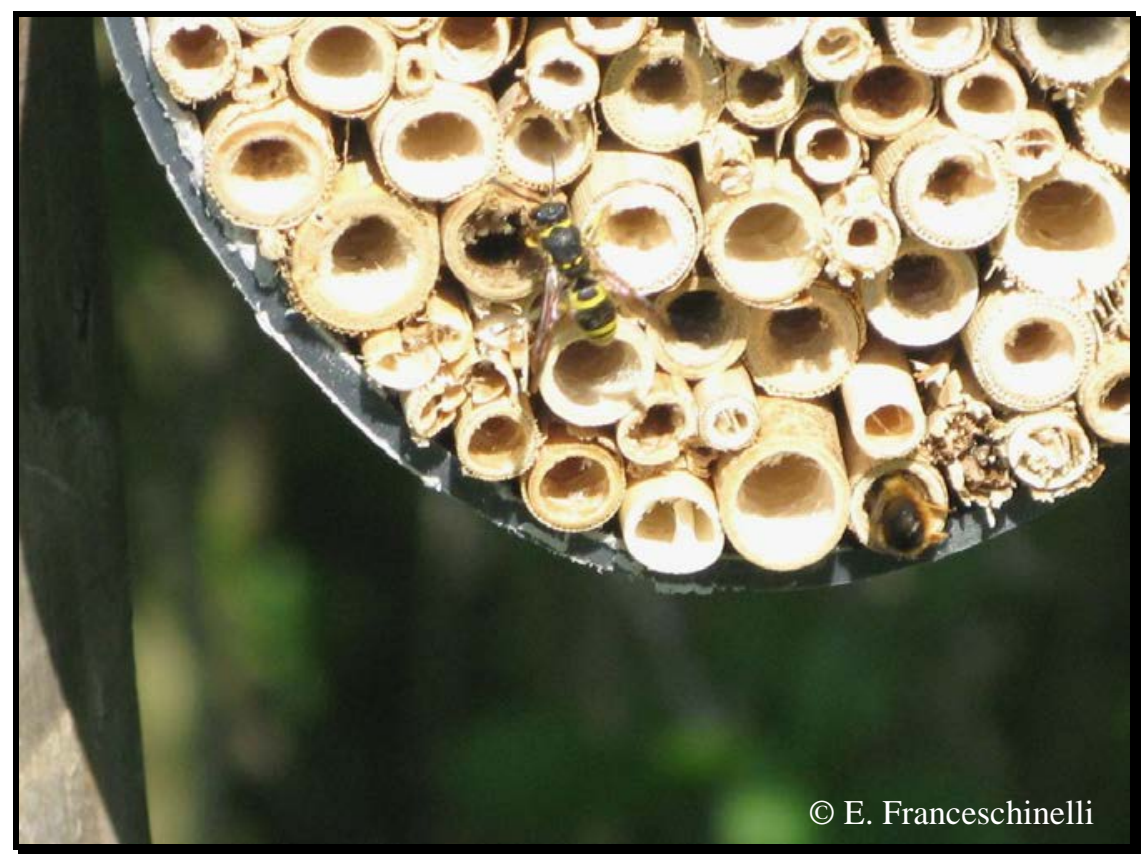




\section{ZUSAMMENFASSUNG}

Die Weltbevölkerung wächst zunehmend und mit ihr der Bedarf an Nahrung und Energie. Um diese steigende Nachfrage durch den Anbau von Marktfrüchten, Futterpflanzen und Pflanzen zur Energiegewinnung zu decken, hat während der letzten Jahrzehnte die landwirtschaftliche Bewirtschaftung und die Umwandlung von seminaturellen Flächen in Ackerland zugenommen. Diese Intensivierung der Landwirtschaft und der steigende Flächenbedarf haben zu einem Rückgang der Biodiversität in der Agrarlandschaft geführt. Der Erhalt der Biodiversität ist jedoch obligatorisch, um die Stabilität von ökosystemaren Dienstleistungen, wie zum Beispiel die Bestäubung von Pflanzen oder die biologische Schädlingskontrolle, welche auf biotischen Interaktionen basieren zu gewährleisten.

Für die sexuelle Reproduktion von Pflanzen ist Bestäubung unerlässlich. Dieses gilt für Wildpflanzen, aber auch geschätzte 75\% der Kulturpflanzen weltweit sind auf die Bestäubung durch Tiere zur optimalen Ertragsbildung angewiesen. Bienen sind hierbei die wichtigsten Bestäuber in der Agrarlandschaft der nördlichen Hemisphäre, jedoch weist der zunehmende Rückgang von Honigbienen und Wildbienen, besonders in landwirtschaftlich intensiv genutzten Gebieten, auf eine zukünftige Bestäuberkrise hin. Die Intensivierung der Landwirtschaft beeinflusst außerdem räuberische Wespen negativ, die einen wichtigen Beitrag zur biologischen Schädlingskontrolle leisten und ebenso Parasitoide, die eine wichtige Rolle hinsichtlich der Regulation der Wirtspopulationen spielen. Der Verlust der Biodiversität von wichtigen funktionellen Gruppen, wie Bestäubern, Räubern und Parasitoiden kann zur Destabilisierung von trophischen Interaktionen und dadurch zu kaskadierendem Artensterben führen.

Das Ziel dieser Studie war die Quantifizierung der Einflüsse von verschiedenene Landschaftselementen und Habitattypen, die repräsentativ für die Agrarlandschaft sind, auf die Bienen- und Wespengemeinschaften und deren Parasitoide, unter Berücksichtigung der wechselnden Wichtigkeit dieser Habitattypen entlang eines Gradienten der Landschaftskomplexität. Die Studie wurde im Umkreis der Stadt Göttingen in Süd- Niedersachsen, Deutschland, durchgeführt.

Im ersten Teil der Arbeit untersuchte ich die Hypothese, dass grasbewachsene Randstreifen als Korridore in der Landschaft funktionieren können und die Fortbewegungen von Hymenopteren in der Landschaft positiv beeinflussen. Zusätzlich 
wurden eventuelle Barriere Effekte durch dichte Hecken geprüft, die laut Hypothese die Fortbewegung der Wildbienen einschränken. Artenreiche Magerrasen galten als Quellhabitate für Bienen, Wespen und deren Parasitoide und verbundene und unverbundene grasbewachsene Randstreifen in verschiedenen Entfernungen vom Quellhabitat wurden ausgewählt, um mögliche Korridoreffekte auf die Abundanz und Artenvielfalt der Zielorganismen zu beobachten. Die dichten Hecken an den Rändern der Magerrasen wurden als Barrieren für foragierende Bienen eingeschätzt. Foragierende Bienen wurden mittels Farbschalen gefangen, während oberirdisch nistende Bienen, Wespen und deren Parasitoide mit Hilfe von standardisierten Nisthilfen aufgenommen wurden. Die Ergebnisse zeigten, dass die grasbewachsenen Randstreifen die Funktion von alternativen Nist- und Foragierhabitaten übernehmen können, wenn semi-naturelle Habitate in der näheren Umgebung vorkommen. Es wurden starke Isolationseffekte auf fast alle Zielgruppen beobachtet. Die Abundanz und Artenvielfalt von foragierenden Solitärbienen, oberirdisch nistenden Bienen, Wespen und deren Parasitoide verringerten sich mit zunehmender Distanz zum Quellhabitat. Die Hummeln bildeten die Ausnahme und zeigten keinen Artenrückgang oder eine verringerte Abundanz. Die Hypothesen, dass grasbewachsene Randstreifen als Korridore die negativen Distanzeffekte in 100m Entfernung mildern können und das dichte Hecken eine Barriere für foragierende Bienen darstellen konnten nicht verifiziert werden.

Im zweiten Teil dieser Arbeit untersuchte ich die relative Wichtigkeit von verschiedene Landnutzungstypen, Landschaftsattributen (der Prozentsatz von Brachen und semi-naturellen Habitaten in der Landschaft) und Landschaftskomplexität für die Artenvielfalt und Abundanz von Bestäubern über einen Zeitraum von drei Jahren. Fünf Habitattypen, die repräsentativ für die hiesige Agrarlandschaft sind, nämlich (i) Weizenfeld, (ii) grasbewachsener Ackerrandstreifen, (iii) Intensivweide, (iv) Brache und (v) Waldrand wurden in 12 nicht-überlappenden Landschaftssektoren mit einem Radius von 1000 m um jeden Habitattyp ausgewählt. Die gewählten Landschaften deckten einen Gradienten an Landschaftskomplexität, der als Anteil von Ackerland gemessen wurde, von strukturreich (14\% Ackerland) bis strukturarm (89\% Ackerland) ab. Die Bestäuberpopulationen wurden mit Hilfe von Farbschalen für foragierende Bienen über drei Jahre und mit standardisierten Nisthilfen über den Zeitraum von zwei Jahren aufgenommen. Die Abundanz und der Artenreichtum der untersuchten Arten 
der bodennistenden Bienen war in erster Linie von Landschaftsattributen und nicht Habitattypen beeinflusst, wobei es sich bei den oberirdisch nistenden Arten gegensätzlich verhielt. In der Studie über drei Jahre verringerte sich der Brachenanteil in den untersuchten Landschaften um über 50\%. Die Abundanz und der Artenanzahl der solitären bodennistenden Bienenarten verringerte sich im gleichen Zeitraum ebenfalls, während Abundanz und Artenanzahl der oberirdisch nistenden Bienen über die Jahre gleich blieb. Die Hypothese, dass die Abundanz der Hummeln positiv mit dem Anteil der Brachen in der Landschaft korreliert ist, wurde verifiziert.

Weiterhin wurde ein positiver Einfluss vom Anteil semi-natureller Habitate in der Landschaft auf die Artenanzahl von solitären bodennistenden Bienen und Hummeln und auf die Abundanz von bodennistenden und oberirdisch nistenden Bienen festgestellt. Die Abundanz und Artenzahl der oberirdisch nistenden Bienen wurde von qualitativ hochwertigen Habitaten mit einem hohen Anteil blühender Pflanzen gefördert, im Gegensatz zu intensiv bewirtschafteten Habitaten (Weizenfeld und Ackerrandstreifen).

Die dritte Untersuchung basierte auf der zweiten Studie. Es wurde das gleiche Versuchsdesign verwendet, um die Auswirkungen von unterschiedlichen Habitattypen und verschieden strukturierten Landschaften auf die trophischen Interaktionen von Bienen, Wespen und deren natürlichen Feinden mithilfe der Nisthilfen über zwei Jahre zu beobachten. Die Abundanz und Artenanzahl der beobachteten Gruppen war in den intensiv bewirtschafteten Habitattypen (Weizenfeld und Ackerrandstreifen) am niedrigsten. Die Parasitierungsrate der Wirte war in beiden Jahren am qualitativ hochwertigen Waldrand am höchsten, aber die Artenzusammensetzung variierte.

Die Shannon-Diversität und die Verbindungsdichte (Linkage density) der Interaktionen der aufgenommenen Nahrungsnetze wurde durch niedrige Habitatqualität negativ beeinflusst. Der Grad der biologischen Verknüpftheit der Arten (Connectance) innerhalb der Interaktionen, der als Maß für die Komplexität des Nahrungsnetzes und die Generalität der Interaktionen gilt, nahm interessanterweise mit abnehmender Landschaftskomplexität zu. Dies könnte ein Indikator für gesteigerte Konsumenteneffekten in einfach strukturierten Landschaften sein.

Abschließend ist festzustellen, dass Bienen, Wespen und ihre Parasitoide in besonderem Maße von der Qualität des Habitats, wie z. B. extensiv bewirtschaftetes Grünland und Waldränder als Quellhabitate in der Agrarlandschaft, abhängen. Jedoch 
besitzen sie die Fähigkeit qualitativ schlechtere Habitate als alternative Nahrungs- und Nisthabitate zu nutzen, wenn sie durch einen gewissen Anteil semi-natureller Habitate in der umgebenden Landschaft unterstützt werden. Intensiv genutzte Flächen, wie Weizenfelder und Ackerrandstreifen und verringerte Landschaftskomplexität führen zu einem Rückgang der Abundanz und der Diversität der Bestäuber, Räuber und Parasitoiden und verändern deren trophische Interaktionen.

Die Ergebnisse der Studien zeigen, dass der Schutz und die Erhaltung von seminaturellen Habitaten essentiell ist, um stabile Populationen von Bienen, Wespen und deren Parasitoiden und damit die von Ihnen bereitgestellten ökosystemaren Dienstleistungen in der Agrarlandschaft zu erhalten. 


\section{ACKNOWLEDGEMENTS}

I sincerely thank my supervisors Prof. Dr. Teja Tscharntke and PD Dr. Carsten F. Dormann for providing the interesting topic of this thesis, their support, advice and constructive feedback on the manuscripts of this thesis.

I wish to acknowledge Prof. Dr. Stefan Vidal for being part of my defence committee.

I thank Dr. Andrea Holzschuh, who developed the individual studies of my thesis and for her encouragement and support during field work and writing of the manuscripts.

I kindly thank the 23 farmers, who gave me permission to work on their fields and Stefan Hellmich and Jeroen Everaars for support during the field work.

Furthermore, I thank Rainer Theunert for reassurance of species identity of numerous bees and wasps.

I thank the people of the Agroecology group for the nice and productive atmosphere, during my time of the $\mathrm{PhD}$ thesis. In particular I like to thank Susanne Schiele, for her friendship, strong support and help during field work, many nice photos and hours on the bee hives and the great job dissecting and recording the numerous trap nest occupants. I thank Brigitte Jünemann, Bianca Tappe and Katrin Schmon for help with sorting the pan trap individuals and the nice hours in the lab.

Special thanks to Ines Vollhardt, for support during the field work and many interesting discussions. My roommate and very good friend Barbara Scheid for her reliability and care. A big thank you goes out to Jochen Fründ, who was always interested in discussions of emerging issues and always had patience to solve statistical and other problems. Furthermore I thank Susanne Jahn, Catrin Westphal, Björn Klatt, Andreas Flohre, Christina Fischer, Georg Everwand, Maximilian von Fragstein und Niemsdorff, Yann Clough, Verena Rösch, Hella Schlinkert, Martin Ludwig and Jutta Gilles for good conversations. 
Finally I am grateful to my family for their support and patience during good and bad times.

I deeply thank Kathrin Stenchly for providing shovels, when necessary, for her sincere friendship, especially during the last weeks of my $\mathrm{PhD}$ thesis. 


\section{PUBLICATIONS}

Krewenka, K., Westphal, C., Steffan-Dewenter I. \& Vaissière, B.E. (2006) Effects of land use changes on an ecosystem service: insect pollination in strawberry fields. Verhandlungen der Gesellschaft für Ökologie, 36, 241.

Krewenka, K., Westphal, C., Vaissière, B.E. \& Steffan-Dewenter, I. (2007) Landscape complexity and bee densities affect the yield of strawberry fields. Verhandlungen der Gesellschaft für Ökologie, 37, 478.

Carré, G., Roche, P. Chifflet, R., Morison, N., Bommarco, R., Harrison-Cripps, J., Krewenka, K., Potts, S.G., Roberts, S.P.M., Rodet, G., Settele, J., SteffanDewenter, I., Szentgyörgi, H., Tscheulin, T., Westphal, C., Woyciechowski, M. \& Vassière, B.E. (2009) Landscape context and habitat type as drivers of bee biodiversity in European annual crops. Agriculture, Ecosystems \& Environment, 133, 40-47.

Krewenka, K., Holzschuh, A., Dormann, C. \& Tscharntke, T. (2009) Do grassy corridors facilitate movement of native pollinators in the agricultural landscape? Deutsche Gesellschaft für allgemeine und angewandte Entomologie, Tagung 2009 in Göttingen, 38.

Krewenka, K., Holzschuh, A., Dormann, C. \& Tscharntke, T. (2009) Choose the easy way - is there dispersal of bees, wasps and hoverflies along corridors? Bayreuther Forum Ökologie, 115, 40.

Krewenka, K.M., Holzschuh, A., Tscharntke, T. \& Dormann, C.F. (2011) Landscape elements as potential barriers and corridors for bees, wasps and parasitoids. Biological Conservation, 144, 1816- 1825.

Krewenka, K.M., Holzschuh, A., Gladbach, D.J., Tscharntke, T. \& Dormann, C.F. (2011) Bee diversity and fallow loss across agricultural landscapes and years. Journal of Applied Ecology (submitted). 
Krewenka, K.M., Holzschuh, A., Tscharntke, T. \& Dormann, C.F. (2011) Species richness and host-parasitoid network structure changing with land-use type and landscape complexity. (in prep.)

Garibaldi, L.A., Steffan-Dewenter, I., Kremen' C., Morales, J.M., Bommarco, R., Cunningham, S:A:, Carvalheiro, L.G., Chacoff, N.P., Dudenhöffer’ J.H., Greenleaf' S.S., Holzschuh, A; Isaacs, R., Krewenka, K.M., Mandelik, Y, Mayfield, M.M., Morandin, L.A., Potts, S.G., Ricketts, T.H., Szentgyörgyi, H., Westphal, C., Winfree, R., Klein, A.M. (2011) Stability of pollination services decreases with isolation from natural areas despite frequent honey bee visits. Ecology Letters, 14, 1062- 1072. 


\section{CURRICULUM VitAE}

\section{Kristin Marie Krewenka}

geboren am 14.05.1978 in Wolfenbüttel

\section{Promotion}

2006 - 2011 bei Prof. Dr. Teja Tscharntke am Fachgebiet Agrarökologie,

Georg-August-Universität Göttingen

"Landscape context of bee, wasp and parasitoid diversity: grass-

strip corridors, fallows and food webs”

\section{Studium}

1999 - $2006 \quad$ Agrarwissenschaften an der Georg-August-Universität Göttingen,

Schwerpunkt: Ressourcenmanagment

Masterarbeit: "Effects of land use changes on an ecosystem

service: insect pollination in strawberry fields” (Note1,0)

Schulbildung

1990 - $1997 \quad$ St.-Bernhard-Gymnasium, Willich-Schiefbahn, Abschluß: Abitur

1988 - 1990 Winfriedschule (Gymnasium), Fulda 